VAGNER VASCONCELLOS

\title{
PROPOSIÇÃO DE UM SISTEMA INTEGRADO DE GESTÃO DE TRANSFORMADORES
}

\author{
Dissertação apresentada à Escola \\ Politécnica da Universidade de São Paulo \\ para obtenção do Título de Mestre em \\ Engenharia
}

São Paulo 


\title{
PROPOSIÇÃO DE UM SISTEMA INTEGRADO DE GESTÃO DE TRANSFORMADORES
}

\author{
Dissertação apresentada à Escola \\ Politécnica da Universidade de São Paulo \\ para obtenção do Título de Mestre em \\ Engenharia \\ Área de Concentração: \\ Engenharia Elétrica
}

Orientador:

Prof. Dr. Luiz Cera Zanetta Júnior

São Paulo 


\section{FICHA CATALOGRÁFICA}

Vasconcellos, Vagner

Proposição de um sistema integrado de gestão de transfor

madores / V. Vasconcellos. -- São Paulo, 2007.

$112 \mathrm{p}$.

Dissertação (Mestrado) - Escola Politécnica da Universidade

de São Paulo. Departamento de Engenharia de Energia e Automação Elétricas.

1.Transformadores e reatores I.Universidade de São Paulo.

Escola Politécnica. Departamento de Engenharia de Energia e Automação Elétricas II.t. 
A sabedoria é a coisa principal; adquire, pois, a sabedoria; sim, com tudo o que possuis adquire o conhecimento.

O temor do Senhor é o princípio do conhecimento; os loucos desprezam a sabedoria e a instrução.

Provérbios de Salomão, cap. 4 v. 7 e cap. 1 v. 7. 


\section{AGRADECIMENTOS}

Primeiramente agradeço a Deus, cujas bênçãos e misericórdias tem se estendido de geração em geração sobre aqueles que o temem e amam.

A meu orientador, Prof. Dr. Luiz Cera Zanetta Jr, pelo direcionamento e orientação essenciais ao sucesso deste trabalho.

A minha esposa, Claudia, pela compreensão, incentivo e apoio dados nas longas horas gastas no decorrer deste trabalho.

A minha mãe Neusa, meu pai Sergio (in memorian) e minha irmã Cinara que sempre me incentivaram a estudar e nunca desistir diante das dificuldades da vida.

A todos que, no presente ou no passado, contribuíram para a execução deste trabalho, em especial aos Engenheiros Marcos Roberto Tassi, Alexandre Nogueira Aleixo e ao Bacharel em Estatística, Alex Alexandre, integrantes do Grupo CPFL Energia. 


\section{RESUMO}

O transformador de potência é o ativo mais valioso e importante de uma subestação, razão pela qual se faz necessário um acompanhamento especial para estes equipamentos. A operação de qualquer equipamento fora de suas condições nominais é sempre uma situação de risco, porém, tal risco pode ser minimizado através de estudos e análises particulares para cada equipamento.Com os transformadores de potência isso não é diferente, as normas e guias de aplicação de cargas em transformadores prevêem períodos de sobrecarga dentro de algumas condições, porém, há uma grande incerteza nesses dados já que cada transformador envelhece de forma diferente ainda que sejam idênticos de projeto e fabricação. Por essa razão se faz necessária uma análise particular de cada equipamento onde serão identificados os riscos em potencial e a partir daí determinado o grau de confiabilidade do equipamento. Com base em informações históricas dos equipamentos e algoritmos desenvolvidos com base nas normas vigentes, foi desenvolvido o Sistema Integrado de Gestão denominado SGT. Através deste sistema será possível armazenar de forma organizada as informações de todas as unidades fornecendo subsídios para uma tomada de decisão minimizando os riscos. Através do Sistema Integrado será possível estabelecer uma base única de consultas, promovendo assim a otimização destes equipamentos face a regulação do setor elétrico. 


\begin{abstract}
The power transformer is the most valuable and important assets of a substation, for that reason is necessary a special attendance for these equipments. The operation of any equipment out of their nominal conditions it is always a risk situation, however, such a risk can be minimized through studies and private analyses for each equipment. Power transformers are not different, the norms and guides of load application foresee overload periods under some conditions, however, and there is a great uncertainty in those data since each transformer ages in a different way although they are identical of project and production. For that reason are necessary peculiar analysis of each equipment where you/they will be identified the potential risks and since then certain the degree of reliability of the equipment. Based in historical informations of the equipments and algorithms developed in agreement with the effective norms, the Integrated System of Management was developed and denominated SGT. Through this system it will be possible to store in an organized way the information of all of the units, supplying subsidies to have a safe decision minimizing the risks. Through the Integrated System it will be possible to establish an only base of consultations, promoting the assets optimization based in the new regulation of the electric section.
\end{abstract}




\section{LISTA DE TABELAS}

LISTA DE FIGURAS

LISTA DE SIGLAS E ABREVIATURAS

LISTA DE SÍMBOLOS

1. INTRODUÇÃ

1.1 Considerações Iniciais...................................................................... 1

1.2 Objetivos e Metodologia....................................................................... 2

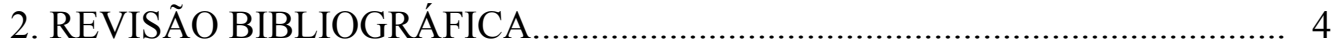

2.1 Definições e Conceitos.......................................................................... 4

- Processo de Revisão Tarifária.................................................................. 4

- Reposicionamento Tarifário................................................................. 5

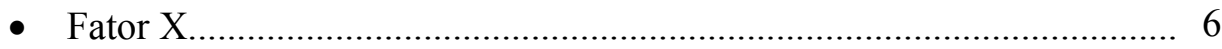

2.2 Transformadores de Potência - Características Principais............................ 7

2.3 Isolação dos Transformadores..................................................................... 8

2.3.1 Óleo Isolante - Dados Históricos................................................. 8

- Processo de Oxidação do Óleo Isolante............................................. 10

2.3.2 Gerenciamento das Condições do Óleo Isolante................................ 12

- Ensaios físico-químicos do Óleo Isolante......................................... 13

- Descrição dos ensaios físico-químicos.............................................. 13

- Cromatografia Gasosa.................................................................. 16

2.3.3 Isolação Sólida dos Transformadores.............................................. 18

2.4 Carregamento e Perda de Vida dos Transformadores............................... 19

2.4.1 Carregamento Admissível dos Transformadores............................. 19

2.4.2 Perda de Vida dos Transformadores................................................ 22

3. METODOLOGIA DE OBTENÇÃO DAS CURVAS CARACTERÍSTICAS.... 24

3.1 Definições sobre a Metodologia Estatística................................................ 24

- Sobre o Software R.................................................................... 24

- Análise de Clusters................................................................... 25

- Distância Canberra............................................................................ 26

- Representatividade........................................................................ 26 


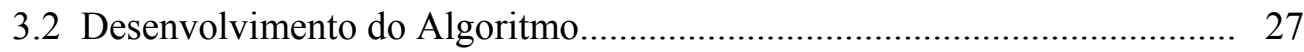

- Obtenção dos Dados......................................................................... 27

3.2.1 Procedimento Clara..................................................................... 27

3.2.2 Saída de Dados do Software R.................................................... 28

3.2.3 Critérios Adotados...................................................................... 28

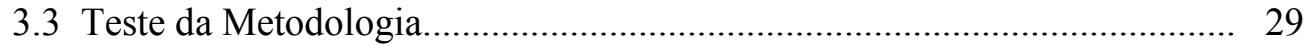

4 - DESENVOLVIMENTO DO SISTEMA INTEGRADO................................ 33

4.1 Sistema de Gestão de Transformadores (SGT) .......................................... 33

4.2 Gerenciamento dos Ensaios de Óleo Isolante........................................... 34

4.3 Módulos do SGT................................................................................ 35

4.3.1 Processamento dos dados das Análises Cromatográficas.................. 37

- Cadastro de Amostras...................................................................... 39

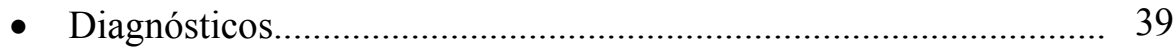

- Visualização Gráfica da Evolução dos Gases................................... 40

4.3.2 Processamento das Análises físico-químicas....................................... 41

- Cadastro das amostras físico-químicas........................................... 43

- Consulta das amostras físico-químicas.............................................. 43

- Unidades com necessidade de intervenção no óleo............................ 43

- Transformadores com restrição........................................................ 44

4.3.3 Dados Técnicos e Manutenção dos Transformadores........................ 45

4.3.4 Cálculo do Carregamento Máximo Admissível dos Transformadores 46

- Cálculo da Perda de Vida dos Transformadores no SGT................. 51

5. ESTUDO DE CASO - AMPLIAÇÃO DA SE PENÁPOLIS........................... 53

5.1 - Definição do melhor ano para o investimento.......................................... 54

- Critérios de Planejamento das Subestações....................................... 54

5.2 Metodologia de Análise.......................................................................... 55

5.2.1 Análise Detalhada da Subestação..................................................... 55

5.2.2 Análise das Curvas Características................................................. 56

5.2.3 Cálculo do Carregamento Máximo Admissível................................ 57

- Cálculo da Perda de Vida do Transformador........................................ 61

5.2.4 Análise dos Resultados Obtidos....................................................... 66

5.2.5 Análise Financeira das Soluções........................................................ 66 


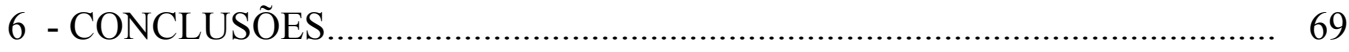

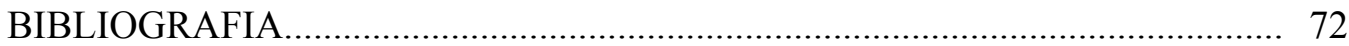

APÊNDICE A - CARACTERÍSTICAS PRINCIPAIS DOS

TRANSFORMADORES DE POTÊNCIA..................................................... i 


\section{LISTA DE TABELAS}

Tabela 2.1 - Valores limite para acompanhamento de transformadores.......... 15

Tabela 2.2 - Valores de Referência para Cálculo da Expectativa de Vida....... 23

Tabela 4.1 - Patamares de Carregamento calculados pelo SGT...................... 50

Tabela 5.1 - Diretrizes de Carregamento de Transformadores - Grupo CPFL. 58

Tabela 5.2 - Carregamento Máximo Admissível - Curva Característica Ano 2005. 59

Tabela 5.3 - Valores de Perda de Vida do Transformador - SE Penápolis...... 63

Tabela 5.4 - Valores Comparativos de Investimentos (Valor Presente).......... 67

Tabela 5.5 - Ganhos obtidos com a postergação da obra................................ 67

Tabela A.1 - Símbolos dos Sistemas de Resfriamento..................................... xvii

Tabela A.2 - Ordem dos Símbolos dos Sistemas de Resfriamento.................. xviii 


\section{LISTA DE FIGURAS}

Figura 2.1 - Processo de Revisão Tarifária.................................................... 6

Figura 2.2 - Processo de oxidação do Óleo Mineral Isolante........................... 11

Figura 2.3 - Equipamento para Ensaio de Cromatografia Gasosa................... 17

Figura 2.4 - Molécula de Celulose............................................................. 18

Figura 2.5 - Comportamento de Aquecimento do Óleo e Enrolamento........... 20

Figura 2.6 - Expectativa de vida para temperatura do ponto quente a $95^{\circ} \mathrm{C} \ldots . .21$

Figura 2.7 - (a) Carregamento Típico e (b) Temperatura Ambiente................. 21

Figura 3.1 - Gráfico de resultados do Procedimento Clara............................. 29

Figura 3.2 - Clusters com as curvas diárias - SE Penápolis............................. 30

Figura 3.3 - Curvas da Média e Mediana - SE Penápolis................................ 30

Figura 3.4 - Gráfico de Representatividade Dem. Máxima- SE Penápolis...... 31

Figura 3.5 - Curva Característica - SE Penápolis (Cluster 1)......................... 32

Figura 3.6 - Curva Característica - SE Penápolis (Cluster 2)......................... 32

Figura 4.1 - Conceito de Gerenciamento Integrado do Transformador............ 34

Figura 4.2 - Tela do Módulo de Carregamento Máximo Admissível e Perda 36

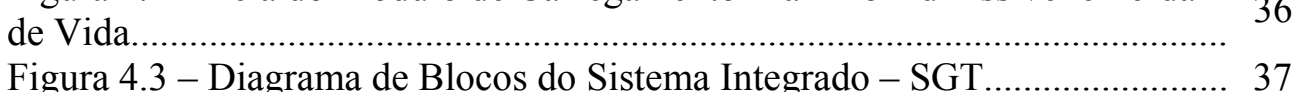

Figura 4.4 - Diagrama de Blocos - Processamento Cromatografia.................. 38

Figura 4.5 - Gráfico de Evolução de Gases - Dióxido de Carbono $\left(\mathrm{CO}_{2}\right)$...... 41

Figura 4.6 - Diagrama de Blocos - Processamento das Análises Físico - 42

Químicas.........................................................................................

Máximo Admissível do SGT.

Figura 4.8 - Carregamento Máximo Admissível - Transformador 25 MVA... 50

Figura 5.1 - Comportamento das Curvas Características (2002-2008)........... 57

Figura 5.2 - Carregamento Máximo Admissível - Ano base 2005................. 60

Figura 5.3 - Carregamento Máximo Admissível - Ano base 2008.................. 61

Figura 5.4 - Curvas de Carga da SE Penápolis - 1980 a 2008......................... 62

Figura 5.5 - Gráfico de evolução dos teores de Oxigênio no Óleo Isolante...... 64

Figura 5.6 - Gráfico de evolução do Índice de Neutralização no óleo isolante. 65

Figura A.1 Projeto Mecânico Típico................................................................ V

Figura A.2 - Vista do Núcleo Montado.......................................................... vii 
Figura A.3 - Enrolamento típico de um Transformador de Potência................ viii

Figura A.4 - Vista da Parte Ativa Montada...................................................... ix

Figura A.5 - Comutador sob Carga - Chave Seletora e Comutadora................ xii

Figura A.6 - Vista geral do tanque................................................................. xiv

Figura A.7 - Buchas Típicas de AT e MT...................................................... xvi

Figura A.8 - Sistema de Resfriamento - ONAN ............................................ xix

Figura A.9 - Sistema de Resfriamento - ONAN/ONAF ................................ $\mathrm{xx}$ 
ABNT - Associação Brasileira de Normas Técnicas;

ANEEL - Agência Nacional de Energia Elétrica;

AT - Alta Tensão;

CODI - Comitê de Distribuição;

CIGRE - International Council on Large Electric Systems

WACC - Weighted Average Cost of Capital;

SGT - Sistema de Gestão de Transformadores;

ONAN - Óleo Natural Ar Natural;

ONAF - Óleo Natural Ar Forçado;

CENPES - Centro de Pesquisas e Desenvolvimento da Petrobrás;

CNP - Conselho Nacional do Petróleo;

DBPC - Diterciário Butil Para Cresol;

MB - Métodos Brasileiros;

NBR - Norma Brasileira

GP - Grau de Polimerização;

CPFL - Companhia Paulista de Força e Luz;

IEC - International Electrotechnical Commission

P.U. - Por Unidade;

IEEE - Institute of Electrical and Electronic Engineers;

ANSI - American National Standards Institute;

MT - Média Tensão;

DGA - Dissolved Gas Analisys 


\section{LISTA DE SÍMBOLOS}

$\theta o_{(j)}$ - Temperatura do topo do óleo no instante de tempo j $\left({ }^{\circ} \mathrm{C}\right)$;

$\theta o_{(j-1)}$ - Temperatura do topo do óleo no instante de tempo j-1 $\left({ }^{\circ} \mathrm{C}\right)$;

$\theta e_{(j)}$ - Temperatura do ponto quente do enrolamento no instante de tempo $\mathrm{j}\left({ }^{\circ} \mathrm{C}\right)$;

$\theta e_{(j-1)}$ - Temperatura do ponto quente do enrolamento no instante de tempo j-1 $\left({ }^{\circ} \mathrm{C}\right)$;

$\theta a_{(j)}$ - Temperatura ambiente no instante de tempo j ( $\left.{ }^{\circ} \mathrm{C}\right)$;

$\theta a_{(j)}$ - Temperatura ambiente no instante de tempo j-1 $\left({ }^{\circ} \mathrm{C}\right)$;

$S_{(j-1)}$ - Carregamento do transformador no instante j-1 (MVA);

$S_{n o m}$ - Potência nominal do transformador (MVA);

$t$ - Intervalo de tempo entre aquisições sucessivas (horas);

$\Delta \theta o n$ - Elevação de temperatura do topo do óleo sobre a temperatura ambiente sob carregamento nominal $\left({ }^{\circ} \mathrm{C}\right)$;

$\tau_{o}$ - Constante de tempo térmica do transformador, para qualquer carga e para qualquer diferença de temperatura, entre a elevação final e a inicial do topo do óleo (horas);

$R$ - Relação entre as perdas sob carga sob carga nominal e em vazio;

n - Expoente utilizado para o cálculo da elevação de temperatura;

m- Expoente utilizado para o cálculo da elevação de temperatura;

$\Delta \theta e n$ - Elevação de temperatura do ponto quente do enrolamento sobre a temperatura do topo do óleo com carregamento nominal $\left({ }^{\circ} \mathrm{C}\right)$;

$\tau_{e}$ - Constante de tempo térmica do enrolamento do transformador (horas). 


\section{CAPÍTULO 1. INTRODUÇÃO}

\subsection{Considerações Inciais}

No modelo atual, o Estado tem o papel de agente regulador, definindo normas, induzindo as ações do setor privado e fiscalizando sua implementação.

As empresas que assumem serviços públicos devem cumprir determinados quesitos de qualidade e desempenho.

A fiscalização tanto dos Órgãos Reguladores como da opinião pública vem sendo feita em relação a estes indicadores, sendo o não cumprimento das responsabilidades sujeito a elevadas penalidades em forma de multas.

Em contra partida os processos industriais têm se mostrado cada vez mais sofisticados e tornando essencial a confiabilidade do sistema de energia elétrica da concessionária. As interrupções mesmo transitórias podem provocar perdas catastróficas de processos com prejuízos incalculáveis no nível industrial e, na retomada de trabalho, prejuízos para a empresa supridora de energia.

O desafio se encontra na busca permanente da harmonia entre as questões técnicas e econômicas, especialmente voltadas à definição e implementação de políticas efetivas de planejamento, projeto, construção, operação, manutenção do sistema elétrico e equipamentos associados, para que seja possível o adequado atendimento e comercialização de energia elétrica, maximizando os resultados, reduzindo riscos de obsolescência e qualidade dos serviços prestados com segurança dos profissionais.

Estudos e pesquisas realizados ao longo de décadas, [1], [24] e [25], indicam que as principais causas de falhas dos transformadores têm relação com os seguintes pontos:

- Sobretensões causadas por descargas atmosféricas e manobras;

- Sobrecorrentes devidos às sobrecargas e curtos circuitos;

- Níveis de isolamento incompatíveis por problemas de especificação ou projeto; 
- Vandalismo, manutenção inadequada, animais, operação indevida;

- Idade e desgaste dos equipamentos e instalações.

Como resultado destas falhas, temos os inconvenientes desligamentos, traduzidos em prejuízos com a falta de energia para o consumidor, que deterioram a imagem e o faturamento, além dos custos de reparos para a Empresa, durante o período de tempo utilizado para sanar a irregularidade, retomada de produção e ou eventuais danos em equipamentos adjacentes ou associados.

O grande desafio atual em relação aos transformadores de potência é gerenciar a operação de um grande número de equipamentos com idade avançada.

De acordo com dados do Relatório Final do CIGRE WG 12.18 [1], há uma grande quantidade de transformadores com idade avançada e perto dos 30 anos, que é o valor de referência para a vida útil. [24] e [25]

Devido à falta de matéria prima e capacidade fabril, será necessária o gerenciamento destes equipamentos até idades superiores há 40 anos em alguns casos [24].

Outro ponto importante é a mudança na legislação de ativos do setor elétrico nacional. De acordo com a nova resolução da 44/1999 da ANEEL, [2] a respeito dos ativos do sistema elétrico, o transformador passa a ter depreciação anual de 2,5\% e, portanto, sua vida útil passa para 40 anos.

Na seqüência deste trabalho serão apresentados alguns conceitos a respeito de revisão tarifária que servirão de referência para o estudo de caso apresentado no decorrer deste trabalho.

\subsection{Objetivo do trabalho}

O objetivo deste trabalho é apresentar o desenvolvimento de um Sistema Integrado de Gestão de Transformadores de Potência, denominado SGT, cuja finalidade principal é promover a gestão integrada deste ativo tão importante das subestações. 
O Sistema Integrado denominado SGT trata-se de um software desenvolvido na linguagem de programação Visual Basic 6.0 que tem a finalidade integrar os dados dos transformadores de potência e tratá-los através de algoritmos específicos, transformando-os em informações úteis que possam ser utilizadas em variadas análises.

Além desta introdução, no capítulo 2 apresentaremos aspectos e características dos transformadores, tipos principais, meios de isolação, critérios de carregamento e alguns conceitos de revisão tarifária.

O método estatístico de análise de Clusters utilizado para a obtenção da curva de carga característica é apresentado no capítulo 3. Ainda neste capítulo apresentaremos uma visão geral do método utilizado e algumas considerações a respeito do software $\mathrm{R}$ que forneceu a curva de carga característica para os estudos de carregamento dos transformadores.

No capítulo 4 apresentaremos o desenvolvimento do Sistema Integrado SGT e suas funcionalidades como, o gerenciamento dos ensaios de óleo isolante, dados técnicos dos transformadores, gerenciamento da manutenção, etc.

No estudo de caso do capítulo 5, utilizando o SGT, fizemos a análise integrada dos dados de um transformador. Simulamos seu Carregamento Máximo Admissível com base na sua curva de carga característica e a partir destes resultados avaliamos a possibilidade de postergação de uma obra visando à otimização dos ativos e ganhos tarifários.

A partir destas simulações foi possível analisarmos os riscos envolvidos e definir o momento mais estratégico para os investimentos em função da atual regulação do Setor Elétrico Brasileiro.

Finalmente no capítulo 6 serão apresentadas as conclusões do trabalho além de possíveis propostas de desenvolvimentos futuros na linha deste trabalho. 


\section{CAPÍTULO 2 - REVISÃO BIBLIOGRÁFICA}

\subsection{Definições e Conceitos}

Neste capítulo apresentaremos alguns conceitos básicos a respeito do processo de revisão tarifária, com a finalidade de dar base ao estudo de caso, onde será proposta a postergação de uma obra visando à obtenção de ganhos tarifários e otimização dos ativos.

Além de alguns conceitos de revisão tarifária, apresentaremos também algumas informações a respeito de transformadores de potência, sendo que informações mais detalhadas sobre transformadores de potência estão apresentadas no Apêndice A deste trabalho.

\section{- Processo de Revisão Tarifária [2], [3], [4] e [5]}

Por delegação da União a concessionária de energia elétrica presta serviço público de distribuição de energia elétrica, na área em que lhe foi dada autorização.

Cabe à Agência Nacional de Energia Elétrica - ANEEL, estabelecer tarifas justas ao consumidor, que garantam o equilíbrio econômico-financeiro da concessionária e estimulem o aumento da efíciência e da qualidade da distribuição de energia elétrica. Com esse objetivo são realizadas revisões tarifárias periódicas.

A revisão tarifária ocorre em duas etapas. A primeira é o reposicionamento tarifário. Durante essa fase, a ANEEL estabelece para cada uma das distribuidoras tarifas que sejam compatíveis com a cobertura dos encargos setoriais e de transmissão, energia comprada, custos operacionais e com a obtenção de um retorno adequado sobre investimentos realizados por essas concessionárias. A segunda etapa da revisão tarifária consiste na definição do Fator X. 


\section{- Reposicionamento Tarifário}

A tarifa de energia elétrica é obtida através da composição de duas parcelas, A e B. A primeira parte denominada de parcela A engloba o custo da energia, encargos de transmissão e os encargos setoriais, sendo repassada diretamente sem qualquer ganho. Por outro lado, a parcela B compreende a remuneração dos investimentos, a depreciação dos ativos e os custos de operação e manutenção dos sistemas elétricos.

A base de remuneração é fundamental para a preservação dos investimentos no serviço público de distribuição de energia elétrica e para proteger os consumidores de preços injustos.

De uma maneira geral, a base de ativos bruta de uma empresa de distribuição é composta pelos ativos imobilizados em serviço, almoxarifado em operação, ativos diferidos, as obrigações especiais e o capital de giro. Basicamente, devem ser desconsiderados da base de remuneração bruta os ativos contemplados na empresa de referência.

A depreciação dos ativos é repassada para a tarifa das concessionárias através de uma cota de reintegração. A cota de reintegração consiste de um percentual aplicado sobre a base de ativos bruta da concessionária e considera também o índice de aproveitamento desses ativos. O índice de aproveitamento tem como principal objetivo garantir que as concessionárias realizem investimentos prudentes em seu sistema.

A remuneração dos investimentos ocorre sobre os ativos líquidos das empresas distribuidoras de energia elétrica, sendo neste caso, desconsideradas as obrigações especiais. A taxa de retorno utilizada para a remuneração dos ativos líquidos é composta pelo custo médio ponderado do custo do capital próprio e pelo custo do capital de terceiros (WACC).

Os custos de operação e manutenção são comparados com os custos de empresas referenciais, construídas pela ANEEL. Esses modelos referenciais são específicos para cada empresa e refletem as condições econômicas e geográficas de suas áreas de concessão, além de níveis de eficiência na prestação dos serviços. A Empresa de Referência é reformulada a cada revisão tarifária, onde os ganhos de 
eficiência são incorporados à modicidade tarifária. A maior eficiência da concessionária é convertida em ganho no período compreendido entre as Revisões Tarifárias.

\section{- Fator X}

$\mathrm{O}$ fator X considera os ganhos de produtividade, a avaliação do consumidor e a manutenção do equilíbrio econômico-financeiro da concessionária. $O$ fator " $X$ " funciona como um redutor dos índices de reajuste das tarifas cobradas dos consumidores, durante os reajustes tarifários anuais das empresas que ocorrerão nos anos seguintes à revisão periódica. Assim, o Fator X é o mecanismo que permite repassar aos consumidores, por meio das tarifas, projeções de ganhos de produtividade das distribuidoras de energia elétrica.

A figura 2.1 apresentada a seguir ilustra de forma gráfica o processo de Revisão Tarifária de uma empresa de distribuição de energia.

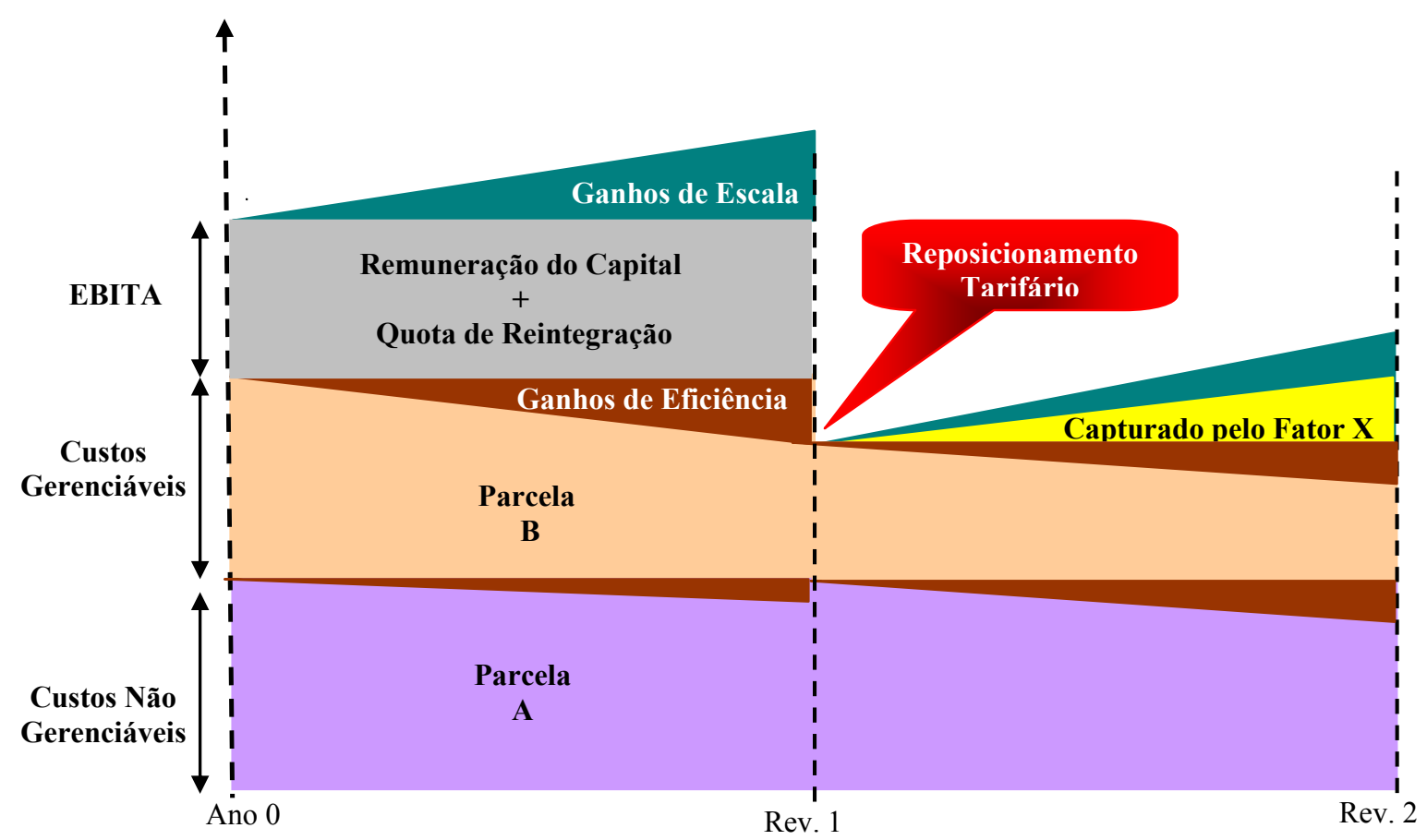

Figura 2.1 - Processo de Revisão Tarifária 


\subsection{Transformadores de Potência - Características Principais}

Para melhor compreensão dos aspectos conceituais relacionados a transformadores de potência, torna-se fundamental o conhecimento de termos e definições adotadas, dentre outras, transformador; auto transformador; banco de transformadores; comutador de derivações; terminais (alta, baixa, neutro, aterramento, etc.); derivação; enrolamentos (alta, baixa, média, primário, secundário, terciário, etc.); tipos de ligação (delta, estrela, série, paralelo), os quais podem ser encontrados nos primeiros capítulos na Normalização Brasileira [7], [8] e [9].

A aplicação de transformadores é muito ampla dentro de um sistema elétrico de potência. Estes equipamentos podem ser utilizados em subestações de usinas geradoras, subestações de sistemas de transmissão, subestações de sistemas de distribuição, redes de distribuição e sistemas fabris.

$\mathrm{Na}$ geração, a tensão das máquinas é da ordem de $13,8 \mathrm{kV}$, que deve ser elevada (transformadores elevadores) para viabilizar a transmissão de energia para utilizadas tensões de $242 \mathrm{kV}$ até $800 \mathrm{kV}$.

Nas subestações de transmissão, a tensão de transmissão é reduzida (transformadores abaixadores) para níveis compatíveis para alimentar as várias subestações de distribuição (subtransmissão) ou subestações de indústrias de médio e grande porte, com tensões de $69 \mathrm{kV}$ a $138 \mathrm{kV}$.

Em subestações de distribuição e indústrias de pequeno porte, as tensões são novamente abaixadas (transformadores abaixadores) visando alimentação de $13,8 \mathrm{kV}$ até $34,5 \mathrm{kV}$.

Para serem utilizadas em sistemas de distribuição residenciais ou comerciais urbano, rural, temos os transformadores abaixadores para tensões de $440 \mathrm{~V}, 380 \mathrm{~V}$, $220 \mathrm{~V}$ e $110 \mathrm{~V}$ instalados em postes.

Além destas aplicações clássicas, existem ainda transformadores reguladores, autotransformadores, transformadores de forno, reatores derivação dentre outros com uso específico em sistemas de potência ou sistemas fabris. 


\subsection{Isolação dos Transformadores}

\subsection{1 Óleo Isolante - Dados Históricos [10], [12], [31] e [59]}

O óleo mineral isolante para transformadores e os óleos empregados em outros equipamentos elétricos, tais como disjuntores, reatores, comutadores são extraídos do petróleo.

O óleo mineral isolante tem duas funções no transformador, uma de isolação e outra de refrigeração. Além disso é uma importante fonte de informações para um diagnóstico das condições do transformador [10].

A construção dos primeiros transformadores ocorreu entre 1890 e 1900, todavia, o óleo mineral isolante é utilizado em equipamentos elétricos desde meados de 1850. Na construção de transformadores o óleo isolante foi usado inicialmente apenas como meio de resfriamento.

Com a elevação da potência unitária e dos níveis de tensão de operação, cresceu a importância dada ao óleo mineral como meio isolante. Associado ao papel, o óleo mineral isolante é o dielétrico líquido mais usado atualmente em transformadores de potência e reguladores de tensão.

De 1890 até 1925 foram utilizados óleos de base parafinica, os quais apresentam alto ponto de fluidez, o que restringe sua aplicação em equipamentos instalados em ambientes de baixa temperatura. A partir de 1926 foi desenvolvido óleo mineral isolante de base naftênica, tendo sido adotado pela General Electric como padrão.

O óleo naftênico tem sido utilizado em todo o mundo com excelente desempenho desde 1926. Porém a partir de 1973, com a crise mundial do petróleo, foram iniciados estudos com a finalidade de substituir o óleo naftênico por óleo parafínico como alternativa importante nestes tempos de crise.

No Brasil, o ano de 1973 marca o início dos estudos objetivando a produção no país de um óleo isolante a partir dos óleos crus disponíveis nas refinarias brasileiras que em sua totalidade eram de base parafínica ou intermediária. Neste mesmo ano a partir do petróleo cru denominado "árabe leve", foram obtidos os óleos isolantes "spindle oil" e "spindle oil modificado", sendo este último submetido a 
ensaios de laboratórios e experiências em transformadores de potência por várias empresas concessionárias do setor de energia elétrica, assim como grupos de trabalho coordenados pelo Centro de Pesquisas e Desenvolvimento da Petrobrás (CENPES).

Os resultados destas pesquisas foram materializados em resoluções do Conselho Nacional de Petróleo (CNP), atual Agência Nacional de Petróleo (ANP).

Na Europa, a partir do ano de 1980 aconteceu a aplicação progressiva de óleo parafínico, até que esse uso fosse generalizado, sem restrições até tensões de $400 \mathrm{kV}$. Os Estados Unidos e a Suécia não utilizam óleo parafínico, em virtude da farta disponibilidade de óleo naftênico. A Espanha utiliza óleo parafínico há mais de 40 anos e o México há pelo menos 15 anos.

Do ponto de vista funcional, não se tem verificado qualquer diferença entre óleos parafínicos, naftênicos ou regenerados. Óleos novos que atendam as prescrições da ANP, sem aditivos de oxidação, são compatíveis, porém a operação de completar nível, deve ser feita preferencialmente com o mesmo tipo de origem.

A compatibilidade da mistura deve ser verificada em laboratório, utilizando a proporção prática. $\mathrm{O}$ resultado da mistura não deve ser inferior ao pior dos óleos individuais.

O óleo isolante deve possuir certas propriedades básicas, para atingir seus objetivos de isolação e refrigeração nos transformadores, tais como:

- Rigidez dielétrica elevada o suficiente para suportar as tensões elétricas impostas pelo tipo de serviço e ambiente de trabalho;

- Viscosidade adequada para que sua capacidade de circular e transferir calor não seja prejudicada;

- Propriedades adequadas às condições climáticas esperadas no local da instalação do equipamento;

- Resistência à oxidação para assegurar uma vida útil satisfatória.

Atualmente, a análise de desempenho do transformador através das condições do óleo isolante é uma importante e poderosa ferramenta de manutenção preditiva do equipamento. 
Esta análise tem como premissa uma avaliação quantitativa e qualitativa de produtos de degradação presentes no óleo mineral, bem como os processos que apressam seu envelhecimento, como agentes de oxidação, umidade, etc.

O óleo contaminado difere dos demais pela presença de água e outras substâncias estranhas à sua composição, substâncias estas que são resultantes do seu processo de oxidação.

\section{- Processo de Oxidação do Óleo Isolante [10], [12] e [31]}

Tendo as finalidades de isolar e refrigerar o equipamento, o processo de oxidação do óleo isolante é inevitável e se inicia desde o enchimento do transformador

Para manter o desempenho satisfatório do transformador, desde o início de funcionamento até um grande período de operação, é fundamental que o óleo mineral isolante possua propriedades adequadas e uma excelente estabilidade a oxidação.

$\mathrm{Na}$ prática existe uma oxidação diferenciada para cada transformador, dependendo de influências externas a que está sujeito, tais como: tipo de óleo utilizado, ciclo de carregamento, sistema de preservação do óleo, quantidades de água e oxigênio no óleo e presença de inibidores de oxidação no óleo.

Um dos processos que contribuem à contaminação de óleo é sua oxidação. Esse processo tem início quando o oxigênio entra em combinação com o hidrocarboneto instável (impurezas), na presença de catalisadores como ferro, cobre, etc. Estes catalisadores são encontrados dentro dos transformadores, e a água tem uma contribuição decisiva no processo de catalização.

Um dos principais desdobramentos indesejáveis da oxidação do óleo mineral isolante é a formação de compostos solúveis que atacam a isolação celulósica num processo irreversível, resultando em redução da vida útil do equipamento.

Em um estágio mais avançado ocorrem os compostos insolúveis, a borra que se deposita sobre a isolação sólida, núcleo, paredes do tanque e aletas de radiadores, prejudicando o processo de refrigeração dos transformadores. 
Existem recursos para se monitorar indiretamente a formação de borra através de ensaios físico químicos no óleo isolante, como os de tensão interfacial, índice de neutralização e fator de potência (fator de dissipação).

Embora o óleo mineral isolante com alto teor de oxidação possa ser recuperado através de processos regenerativos, este procedimento não restaura a perda de vida útil já sofrida do equipamento.

A fim de se estender a vida útil dos óleos minerais isolantes, inibidores de oxidação podem ser adicionados aos mesmos. O inibidor mais utilizado é o Diterciário Butil Para Cresol, (DBPC), que reage preferencialmente com os radicais livres e peróxidos, formando produtos mais estáveis. A proporção de uso deste antioxidante sintético é de no máximo $(0,3 \pm 0,03) \%$ massa / massa.

O diagrama de blocos mostrado na figura 2.2 a seguir foi extraído da referência [10] e ilustra o processo de oxidação do óleo mineral isolante.

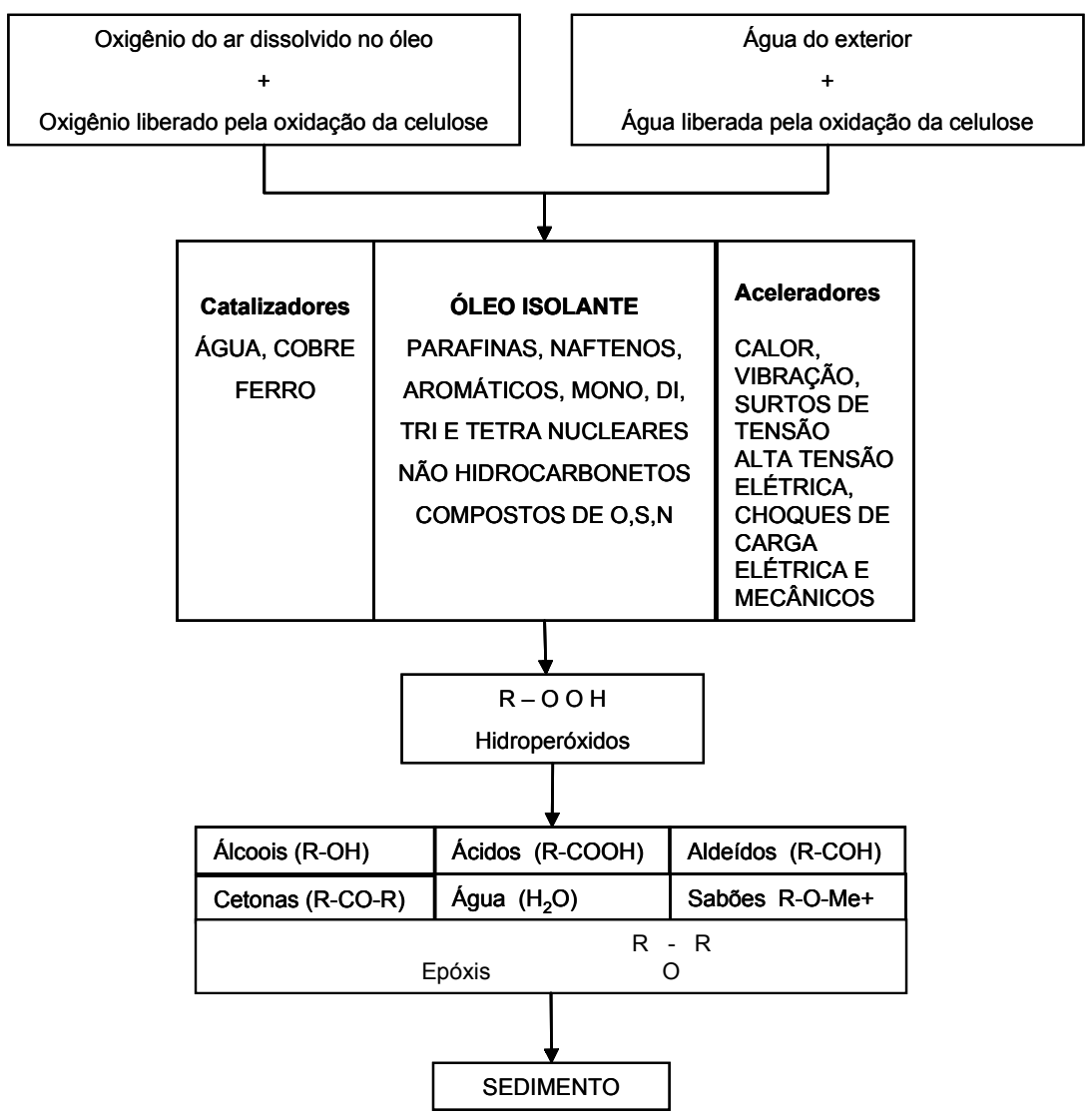

Figura 2.2 - Processo de oxidação do óleo mineral isolante. 


\subsubsection{Gerenciamento das Condições do Óleo Isolante}

Além de constituir parte fundamental para a operação dos transformadores de potência, o óleo isolante também é uma importante fonte de informações a respeito das condições dos equipamentos.

Através de uma sistemática de ensaios é possível obtermos diagnósticos e detectarmos falhas incipientes evitando transtornos e prejuízos de grande monta.

Há vários ensaios que podem ser realizados no óleo isolante, porém, os principais e mais utilizados são os ensaios físico-químicos e a cromatografia gasosa, [10], [11] e [12].

Um outro tipo de ensaio que pode ser feito no óleo isolante é a medição do Teor de Furfural (2FAL) dissolvido no óleo isolante.

Através deste ensaio é possível se ter uma boa idéia de como está ocorrendo o envelhecimento do papel isolante.

Algumas empresas realizam este ensaio de forma sistemática e utilizam os valores como auxílio na tomada de decisão sobre a retirada ou não de um equipamento de operação a fim de se evitar falhas catastróficas. [41], [42] e [43]

Tendo em vista a riqueza de informações que pode ser obtida através das análises dos resultados de ensaio do óleo isolante, vários estudos vem sendo desenvolvidos onde através de técnicas de inteligência artificial tem se obtidos alguns diagnósticos da condição dos transformadores com base em tais informações [39] e [40].

Além do óleo mineral isolante largamente utilizado nos equipamentos elétricos várias pesquisas vêm sendo realizadas onde há o emprego de óleo vegetal para a isolação e refrigeração de equipamentos elétricos.

Uma das vantagens do óleo vegetal em relação ao mineral é o fato da biodegrabilidade, razão pela qual é considerado um fluído isolante ecologicamente correto.

Além disso, com a utilização do óleo vegetal é possível extrair potências maiores dos transformadores em função deste trabalhar com temperaturas maiores. 
Essa elevação de temperatura maior em relação ao óleo mineral permite a compactação de equipamentos em projetos novos ou ainda exploração de potências maiores no caso de repotencialização de equipamentos já existentes.

Alguns estudos vem sendo realizados no âmbito de desenvolvimento de novos equipamentos e ou substituição do óleo mineral por vegetal visando o aumento da vida útil dos equipamentos devido a menor agressividade do óleo. [45] e [46].

Outro ponto importante do óleo vegetal é a não presença de componentes de enxofre no óleo, evitando os problemas de enxofre corrosivo que vem atacando sistematicamente alguns equipamentos em âmbito nacional e internacional. [47].

\section{- Ensaios físico-químicos do óleo isolante [10] e [12]}

Através destes ensaios é possível se determinar as características físicas e químicas do óleo mineral isolante. Com os resultados determina-se o grau de deterioração e contaminação em que se encontra o óleo.

Baseado nesses ensaios é possível determinarmos o momento correto de proceder o tratamento ou regeneração do óleo de acordo com os valores que se encontram fora do especificado.

A determinação da hora correta de se intervir no óleo isolante tem influência direta no envelhecimento e confiabilidade dos transformadores.

\section{- Descrição dos ensaios físico-químicos [12]}

Cor: O óleo isolante novo tradicionalmente é amarelo pálido e límpido, isento de materiais em suspensão. A cor é geralmente aceita como um índice do grau de refino. A medida que o óleo vai deteriorando, sua cor muda tornando-se mais escura.

$\mathrm{O}$ número referente a cor, estando elevado representa envelhecimento, contaminação, deterioração, presença de decomposição de arcos elétricos.

Índice de Neutralização: Medida da quantidade de materiais ácidos presentes. Quando os óleos encontram-se em serviço, envelhecem naturalmente. Assim, a acidez e, portanto, o índice de neutralização aumenta. Um elevado índice de 
neutralização indica que o óleo encontra-se contaminado por vernizes, tintas e outros materiais.

Fator de dissipação ou fator de potência: Mede as perdas dielétricas quando o fluído está sujeito à aplicação de uma fonte elétrica de corrente alternada. É o coseno do ângulo de fase entre a tensão senoidal aplicada ao óleo e a corrente resultante. Um elevado valor de fator de dissipação ou fator de potência representa a presença de contaminantes ou produtos em deterioração, tais como umidade, carbono ou materiais condutores, sabões metálicos e produtos de oxidação.

Tensão Interfacial: É a força de tração que se forma entre as moléculas quando existe uma superfície de separação entre dois líquidos. No caso de óleo e água uma redução na tensão interfacial indica, com antecedência, o início da deterioração do óleo. Quando certos contaminantes como sabão, tintas, vernizes e produtos de oxidação estão presentes no óleo, a resistência da película de óleo é reduzida. A presença destes contaminantes é prejudicial, ao atacar o isolamento e interferir no sistema de resfriamento dos isolamentos internos.

Teor de água: Em sistemas de isolamento elétrico uma baixa quantidade de água é necessária para se ter valores aceitáveis de rigidez dielétrica e fator de dissipação (fator de potência). Valores elevados de teor de água podem degradar as propriedades isolantes do óleo, contribuindo para a deterioração da isolação de celulose.

Rigidez dielétrica: É a propriedade de um dielétrico de suportar tensão elétrica, medida pelo gradiente de potencial sob o qual se produz uma descarga. A redução do valor de rigidez dielétrica de um óleo indica a possibilidade de aumento de quantidade de partículas sólidas em suspensão (sujeira, partículas condutoras, partículas de carbono, etc.) e/ou aumento da presença de água dissolvida e/ou água livre em suspensão, resultando na necessidade de tratamento ou substituição do óleo utilizado. 
Densidade: é a relação de massas de uma determinada substância (óleo mineral isolante) e outra substância do mesmo volume (em geral a água à temperatura de $4^{\circ}$ C). Indica uma característica intrínseca do óleo isolante. Possui um valor limite na determinação da qualidade de um óleo para fins de aplicações elétricas da ordem de 0,86 .

Os ensaios físico-químicos citados anteriormente apresentam valores limites mínimos ou máximos, que variam de acordo com cada empresa. Os valores mostrados na tabela 2.3 a seguir são utilizados como referência nas empresas que compõem o Grupo CPFL.

Tabela 2.1 - Valores Limite para acompanhamento de transformadores, [13]

\begin{tabular}{|c|c|c|c|}
\hline Ensaio Realizado & Limite Inferior & Limite Superior & Unidade \\
\hline Cor & - & 5 & \\
\hline Densidade & 0,86 & 0,9 & \\
\hline Fator de dissipação & - & 15 & $\%$ \\
\hline Rigidez Dielétrica & 50 & - & $\mathrm{kV}$ \\
\hline Acidez & - & 0,3 & $\mathrm{mgKOH} / \mathrm{g}$ \\
\hline Tensão interfacial & 20 & - & $\mathrm{mN} / \mathrm{m}$ \\
\hline Teor de água & - & 35 & $\mathrm{ppm}$ \\
\hline
\end{tabular}

Por apresentarem valores mínimos e máximos, é bem mais simples analisar um ensaio físico-químico do que uma cromatografia gasosa.

Porém, mesmo sendo mais simples tais ensaios são de fundamental importância uma vez que detectam problemas sérios nos transformadores.

Os valores limites variam de acordo com a classe de tensão em que opera o equipamento, os resultados coletados nos ensaios do óleo isolante indicam o que está acontecendo ao equipamento e se trata de uma valiosa fonte de informações para se acompanhar o envelhecimento do óleo isolante bem como do transformador.

Dependendo do valor que esteja fora dos limites podemos resolver o problema do óleo através de tratamento a termovácuo, substituição ou regeneração do óleo isolante. No tratamento a termovácuo o óleo sofre o processo de secagem e retirada de gases, enquanto que no processo de regeneração além dos processos anteriormente citados o óleo ainda passa por um processo físico-químico que restaura suas características físico-químicas como acidez, tensão interfacial, etc. 


\section{- Cromatografia Gasosa [11]}

A análise cromatográfica dos gases dissolvidos no óleo isolante, denominada de forma genérica como Cromatografia Gasosa (Dissolved Gas Analisys - DGA) é uma das mais efetivas maneiras de determinar previamente defeitos ou falhas em desenvolvimento em equipamentos imersos em óleo isolante, sendo utilizada para monitorar de forma preditiva as condições destes equipamentos em operação. Desenvolvida nos anos 60, é reconhecida mundialmente como uma das principais ferramentas para prevenir falhas catastróficas de transformadores de potência.

A interpretação dos resultados de ensaios de cromatografia gasosa pode ser considerada uma arte já que ainda não se dispõe de critérios exatos de análise [10].

No caso deste tipo de ensaio, o que mais conta é o histórico de gases dissolvidos no óleo isolante e não simplesmente o valor do ensaio atual.

O primeiro passo para o diagnóstico de anomalias em transformadores é feito a partir da amostra de óleo isolante. Assim como o exame de sangue propicia ao médico elementos para conhecer a sua saúde do seu paciente, a cromatografia gasosa do óleo isolante propicia à Engenharia de Manutenção subsídios para o entendimento do estado real do transformador.

Existem vários métodos normalizados e reconhecidos para análise dos gases dissolvidos no óleo isolante, os quais requerem uma amostra de óleo. A amostra é manipulada de modo que seja possível remover ou extrair os gases dissolvidos no óleo.

Estes gases são separados com o uso de um Cromatógrafo, que é um instrumento de precisão composto de algumas colunas e detectores que podem variar de um até três. O gás extraído da amostra de óleo é injetado no Cromatógrafo, onde as suas colunas separam os vários tipos de gases. Ao terminar a separação dos gases, estes fluem pelos detectores que têm capacidade de quantificar estes gases. A figura 2.2 mostra um cromatógrafo utilizado para a realização dos ensaios de cromatografia gasosa em óleo isolante.

Desta forma, primeiro passo para o diagnóstico de anomalias em transformadores é feito a partir da amostra de óleo isolante, fundamental para subsidiar decisões de operação e manutenção de unidades transformadoras. 
- A ocorrência de um arco elétrico no óleo isolante dá origem a grandes quantidades de hidrogênio $(\mathrm{H} 2)$ e acetileno $(\mathrm{C} 2 \mathrm{H} 2)$, com pequenas quantidades de metano (CH4) e etileno (C2H4).

- Descargas elétricas de baixa energia produzem hidrogênio e metano, com pequenas quantidades de etano $(\mathrm{C} 2 \mathrm{H} 6)$ e etileno $(\mathrm{C} 2 \mathrm{H} 4)$.

- Caso a falha atinja a celulose, em ambos os casos também haverá a formação de monóxido e dióxido de carbono ( $\mathrm{CO}$ e $\mathrm{CO} 2)$.

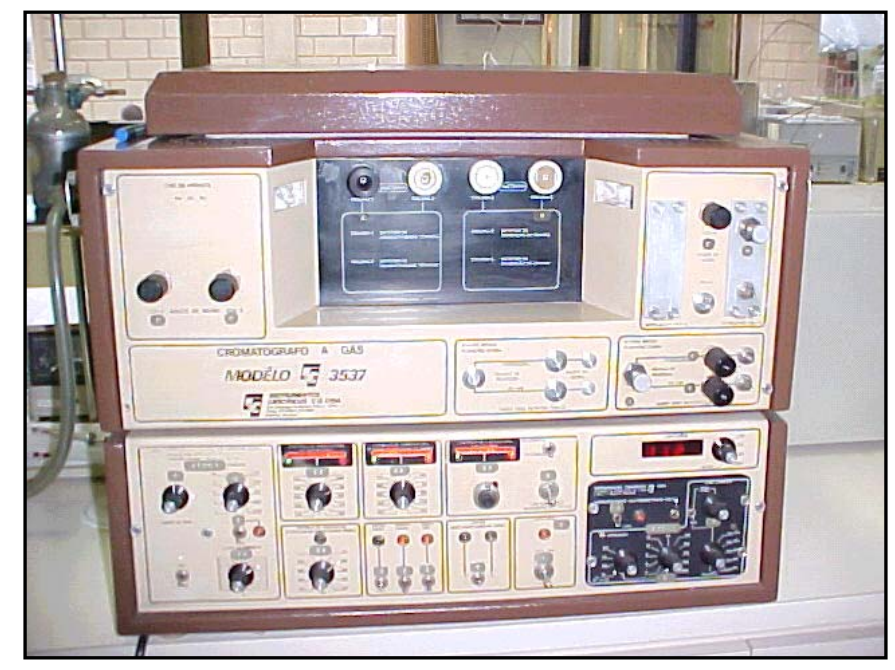

Figura 2.3 - Equipamento para Ensaio Cromatografia Gasosa (Cromatógrafo)

A análise desses gases permite identificar a ocorrência de defeitos e/ou falhas associadas aos materiais dielétricos envolvidos, ou seja, permite determinar a condição de operação dos equipamentos bem como monitorá-los ainda em estágio de aceitação tanto na fábrica quanto em campo.

Nesse campo da análise cromatográfica, foram desenvolvidos alguns estudos, que tentam estabelecer diagnósticos, utilizando técnicas de inteligência artificial [40] e [41].

Além disso, há dispositivos no mercado onde é possível monitorar alguns gases chaves no óleo isolante ou sistemas mais sofisticados que executam até uma cromatografia em tempo real do transformador. 
A referência [48] apresenta um trabalho desenvolvido na área de monitoramento de transformadores onde se utilizou um equipamento para fazer o monitoramento de um conjunto de gases e a partir do qual estabelecer diagnósticos ao equipamento.

Tais dispositivos só se justificam em transformadores de grande porte e de importância muito elevada devido ao seu alto custo de implantação. Em transformadores de porte menor o uso dos ensaios de cromatografia gasosa ainda é a ferramenta mais adequada para acompanhamento das condições do equipamento.

Há vários métodos de acompanhamento utilizados para diagnóstico de transformadores de potência através de ensaios de cromatografia gasosa no óleo isolante, sendo que os principais são:

- Método NBR 7274/82 [11] e [30]

- Método Laborelec [13] e [14]

- Método de Rogers [15] e [16]

\subsubsection{Isolação Sólida dos Transformadores [22] e [23]}

O papel isolante é formado por fibras longas cujo principal constituinte é a celulose. Uma molécula de celulose é um polímero linear formado por uma cadeia de anéis de glicose unidos através de ligações químicas denominadas glicosídicas. A figura 2.3 a seguir mostra uma molécula de celulose.

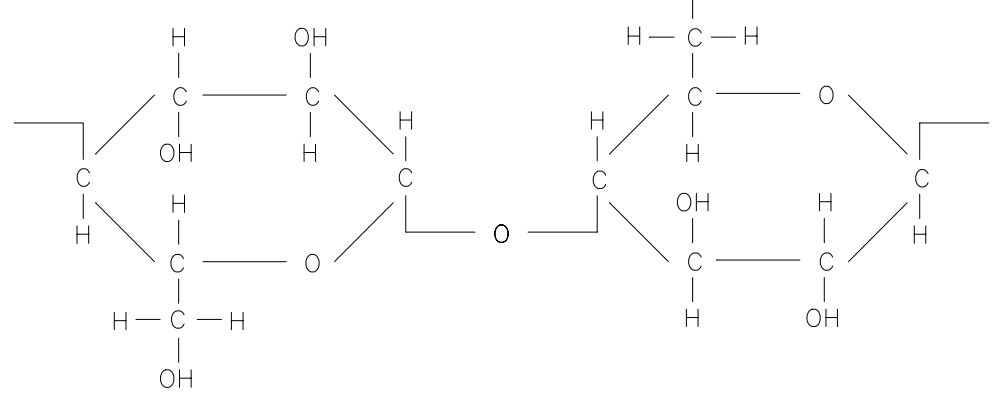

Figura 2.4 - Molécula de Celulose 
O número de anéis de glicose por fibra de celulose é da ordem de 1300 unidades para o papel tipo kraft nacional, novo, medido através de grau de polimerização viscosimétrico.

A medida que o papel envelhece, ocorre o rompimento dos anéis de glicose, diminuindo-se o comprimento da molécula. Esta degradação provavelmente se inicia pela hidrólise e oxidação da celulose, resultando na diminuição da resistência mecânica do papel, que caracteriza o seu envelhecimento.

Os principais fatores que influenciam a degradação da celulose são a presença de água, presença de oxigênio, presença de agentes oxidantes (peróxidos) e exposição à temperatura elevada.

O Grau de Polimerização do papel isolante (GP) decresce da ordem de 1200 / 1300 (papel novo) até aproximadamente 100 (estado degradado) [13].

Verificou-se que existe uma correlação entre o Grau de polimerização (nível) e as propriedades mecânicas do papel. Por exemplo, quando o Grau de Polimerização é inferior a 150 o papel não possui mais resistência mecânica adequada.

Desta forma, transformadores que se encontram em operação com Grau de Polimerização desta ordem tem sua confiabilidade reduzida a praticamente zero. No caso de ocorrência de curto circuito no sistema de distribuição (fenômeno cotidiano), o transformador fica submetido a esforços longitudinais e verticais que comprimem a isolação de papel.

Com o término do da falta no sistema, o papel não retorna a condição original, devido a ausência de elasticidade, podendo provocar o rompimento da isolação celulósica ou diminuição permanente dos isolação dielétrica e uma falha elétrica poderá ocorrer a qualquer instante.

\subsection{Carregamento e Perda de Vida dos Transformadores}

\subsubsection{Carregamento Admissível dos Transformadores}

O Carregamento do transformador está associado à elevação de temperatura, em relação à temperatura ambiente, que os enrolamentos alcançam quando por eles circula a corrente que alimenta a carga. 
A corrente nominal, associada à potência nominal, refere-se à temperatura especificada de projeto, compatível com o tipo de material isolante utilizado na construção do equipamento.

A figura 2.5 a seguir apresenta as constantes de tempo do óleo e enrolamento de um transformador durante um ciclo de carga de dois patamares. Como pode ser visto, as constantes térmicas são bem diferentes, enquanto o óleo atinge o seu valor máximo em aproximadamente 3 horas, o enrolamento atinge em 15 minutos.

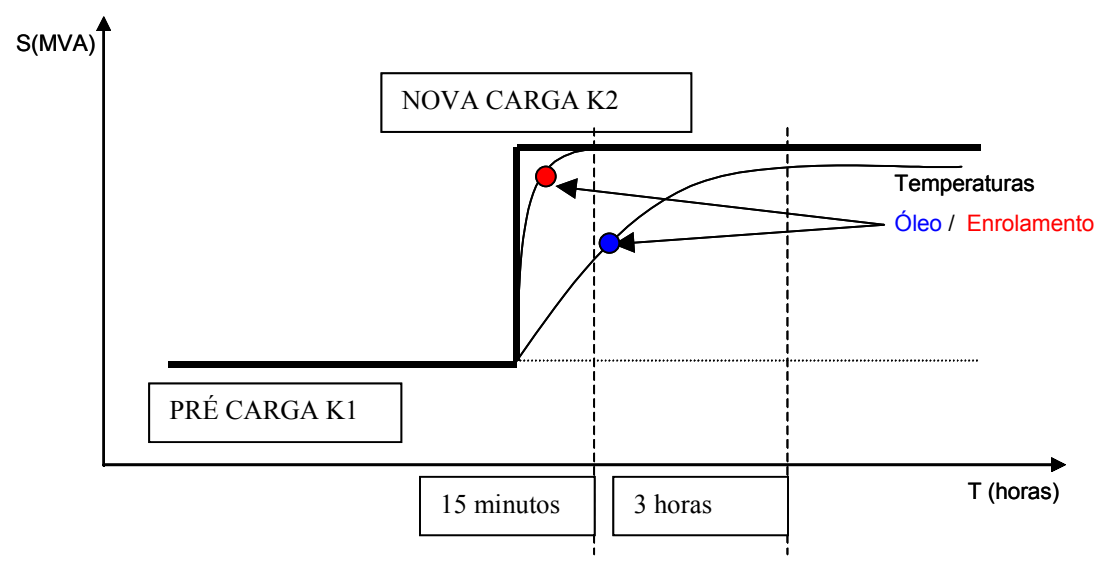

Figura 2.5 - Comportamento de Aquecimento do Óleo e Enrolamento.

Assim, quando se considera a temperatura ambiente constante de $30^{\circ} \mathrm{C}$ e carga constante e igual à nominal, os enrolamentos do transformador estarão submetidos à elevação de temperatura especificada.

Nesta condição, considerando-se que as condições de manutenção do equipamento são adequadas (qualidade do óleo isolante, estanqueidade, integridade mecânica e elétrica, etc.), o consumo da vida útil do equipamento se resume ao envelhecimento do material isolante.

A norma brasileira NBR 5416/97 [11] estabelece valores de referência para a vida útil, baseada apenas no envelhecimento do papel na temperatura especificada. No caso da maioria dos transformadores, a vida útil nessa condição seria de 7,5 anos, conforme pode ser visto na figura 2.6 
Gráfico de Expectativa de Vida

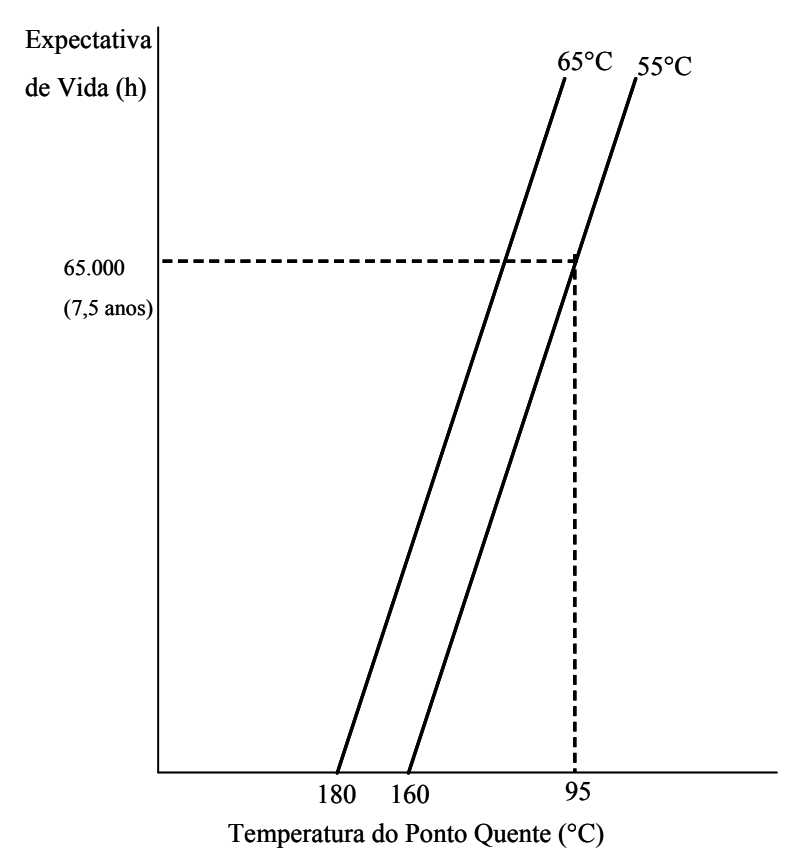

Figura 2.6 - Expectativa de vida para temperatura do ponto quente a $95^{\circ} \mathrm{C}$.

Entretanto, quando em operação em uma subestação, tanto a temperatura ambiente quanto a curva de carga da subestação impõem condições diferentes das acima descritas, o que permitem, felizmente, o uso do transformador por períodos maiores que 7,5 anos.

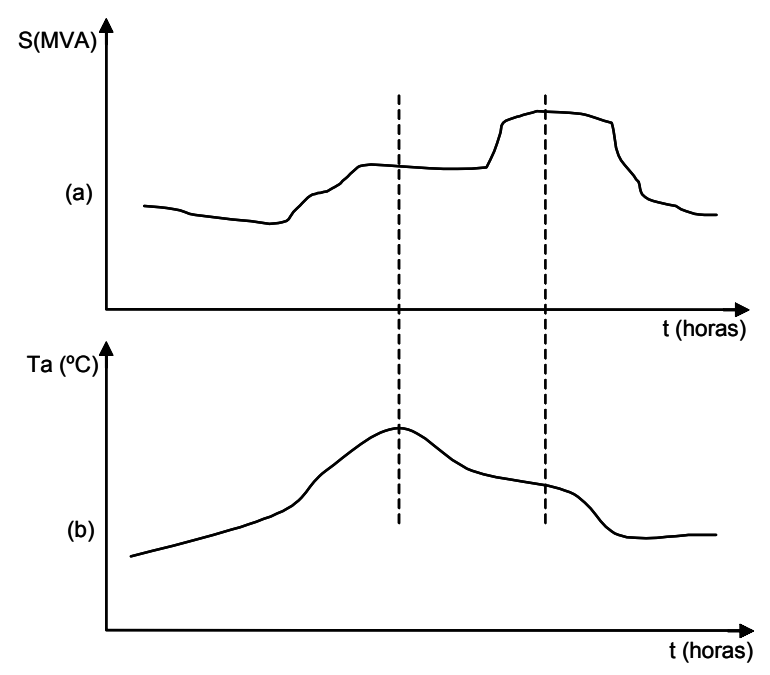

Figura 2.7 - (a) Carregamento Típico e (b) Temperatura Ambiente. 
Baseado nos parâmetros físicos dos equipamentos e outros decorrentes do ensaio de aquecimento , bem como na curva de carga de cada subestação, a avaliação dos carregamentos aplicados aos equipamentos permite a liberação de potências dos transformadores por determinados períodos e em função da temperatura ambiente.

Utilizando algoritmos desenvolvidos com base nas equações de aquecimento da norma NBR 5416/97 [11], a avaliação é feita no SGT o qual permite estimar, hora a hora, as temperaturas no chamado "ponto quente" dos enrolamentos do transformador, associando-se, a cada ciclo de carga diário, um consumo acumulado de vida útil.

Os níveis de consumo de vida esperados ou admitidos em cada condição de operação, bem como os riscos operativos associados juntos, estabelecem os carregamentos liberados, os quais são classificados, em ordem crescente de temperatura de operação e risco de acordo com a Orientação Técnica que regulamenta o carregamento dos transformadores das empresas do Grupo CPFL [18].

De acordo com a referência [18] os carregamentos dos transformadores de potência na CPFL são classificados como:

- Carregamento em Condições Normais de Operação;

- Carregamento Planejado Acima das Condições Normais;

- Carregamento de Emergência de Longa Duração;

- Carregamento de Emergência de Curta Duração.

Todo o equacionamento utilizado no desenvolvimento do Módulo de Carregamento Máximo Admissível do SGT está sendo apresentado no capítulo 4 deste trabalho.

\subsubsection{Perda de Vida dos Transformadores}

No tocante a operação acima das condições nominais há dois pontos principais que devem ser salientados, perda de vida útil e confiabilidade. 
Em relação a perda de vida, com base na NBR-5416/97, [11] podemos admitir que um transformador tem sua vida útil reduzida de acordo com a lei de Arhenius desde que o sistema de isolação papel / óleo estejam dentro de alguns valores mostrados na tabela 2.11 a seguir.

A equação que expressa a perda de vida percentual da isolação sólida é descrita como: [11] e [39].

$$
P V^{\%} \%_{(j)}=\sum_{j=1}^{24} 100 \Delta t 10^{-\left(A+\frac{B}{\theta e_{(j)}+273}\right)}
$$

Onde:

$P V \%_{(j)}-$ Perda de vida percentual no instante $(\mathrm{j})$

$A$ e $B=$ são constantes da curva de expectativa de vida.

$A=-14,133$ para transformadores com elevação de temperatura de $55^{\circ} \mathrm{C}$.

$A=-13,391$ para transformadores com elevação de temperatura de $65^{\circ} \mathrm{C}$.

$B=6972,15$.

$\theta e_{(j)}=$ temperatura do ponto mais quente do enrolamento em ${ }^{\circ} \mathrm{C}$.

$\Delta t=$ Intervalo de tempo em horas

Tabela 2.2 - Valores de Referência para Cálculo da Expectativa de Vida [11].

\begin{tabular}{|l|l|}
\hline Ensaio & Limites \\
\hline Umidade no Papel (\% por massa) & $<1$ \\
\hline Índice de Neutralização (mg KOH/g) & $<0,1$ \\
\hline Teor de $\mathrm{O}_{2}(\mathrm{ppm})$ & $<3000$ \\
\hline
\end{tabular}

Quando o óleo e ou papel isolante ultrapassam os valores da tabela 2.11 a expectativa de vida calculada pela Lei de Arhenuis servirá apenas de referência, pois o grau de envelhecimento obtido não corresponderá à idade cronológica do transformador [11]. 


\section{CAPÍTUlO 3 - METOdOLOGIA DE OBTENÇÃO DAS CURVAS CARACTERÍSTICAS}

As curvas de carga são peças fundamentais para a determinação do carregamento máximo admissível dos transformadores de potência. Com base nas curvas de carga é possível calcularmos as máximas temperaturas do óleo e enrolamento dos transformadores com base na NBR-5416/97. [11]

Devido à importância das curvas de carga, para a análise de carregamento dos transformadores, foi desenvolvido um módulo no SGT que faz um tratamento estatístico num grupo de curvas com a finalidade de se determinar uma curva característica que represente o carregamento do transformador durante o ano.

Isso foi possível através da análise de Clusters, ferramenta estatística que separa as curvas de carga em grupos conforme a similaridade existente entre elas.

A seguir será apresentado o desenvolvimento desta metodologia, através de um software estatístico denominado R, que contempla várias ferramentas de análise, inclusive a análise de Clusters, utilizada no desenvolvimento do SGT.

\subsection{Definições sobre a metodologia estatística}

\section{- Sobre o Software R}

O R, é um software estatístico e gráfico. Ele possui um conjunto integrado de programas para manipulação de dados, cálculos e gráficos. Entre outras características permite:

- Manipulação e armazenamento de dados,

- Operadores para cálculo sobre variáveis indexadas e cálculo matricial,

- Uma vasta, coerente e integrada coleção de ferramentas para análise de dados,

- Capacidades gráficas para análise exploratória de dados, que permitem a visualização dos resultados obtidos,

- Uma linguagem de programação bem desenvolvida, simples e eficiente, que inclui estruturas condicionais, cíclicas, funções recursivas e capacidade de entrada e saída de dados. 
Isso caracteriza o software R como um sistema coerente e não apenas como um conjunto de ferramentas específicas e inflexíveis, ao contrário de outros programas de análise de dados.

\section{- Análise de Clusters}

Os pesquisadores de mercado muitas vezes encontram situações que melhor se resolvem através da definição de grupos homogêneos de objetos, sejam eles indivíduos, empresas ou produtos.

As estratégias são baseadas na identificação de pequenos grupos da população, de modo que a segmentação não é possível sem uma metodologia objetiva. Em todos os casos, a pesquisa pela "estrutura natural” entre as observações é baseada em perfis multivariados.

A necessidade de classificar elementos em grupos por suas características está presente em várias áreas do conhecimento, como nas ciências biológicas, ciências sociais e comportamentais, ciências da terra, medicina, informática, entre outras.

A técnica mais comumente utilizada para esse propósito é a Análise de Clusters (Agrupamentos). A análise de cluster busca agrupar elementos de dados baseando-se na similaridade entre eles. Os grupos são determinados de forma a obter-se um elevado grau de homogeneidade dentro dos grupos e um alto nível de heterogeneidade entre eles.

O termo Clustering é usado para descrever métodos de agrupamento de dados não classificados. A proximidade do padrão é usualmente medida por uma função de distância (métrica), Distância Euclidiana, Manhattan, Canberra, etc.

Neste trabalho esta técnica foi escolhida para promover o agrupamento de curvas de carga similares, com a finalidade de se obterem curvas representativas do carregamento do transformador ao longo do ano.

Foram utilizadas as rotinas de otimização do software R, para a obtenção dos clusters e da curva característica, não sendo explorada a totalidade dos recursos deste pacote, pois esta não é a finalidade principal deste trabalho. 


\section{- Distância Canberra}

Sejam X e Y dois vetores tais que: $X=(x 1, \ldots, x n)$ e $Y=(y 1, \ldots, y n)$. A definição da distância entre X e Y pela métrica Canberra é:

$$
D_{x y}=\sum_{i=1}^{24} \frac{\left(\left|x_{i}-y_{i}\right|\right)}{\left(\left|x_{i}+y_{i}\right|\right)} \quad 1 \leq \mathrm{i} \leq 24
$$

Onde:

$x_{i}$ - Curva de Carga Diária 1

$y_{i}$ - Curva de Carga Diária 2

Com esse método, os termos nulos, sejam no numerador ou no denominador, são omitidos na soma e considerados como valores não existentes e portanto, não influenciam nos resultados finais. A principal vantagem obtida na escolha da Métrica Canberra, em relação as demais, foram resultados mais precisos encontrados nas simulações, além de não haver a necessidade de um preparo prévio da base de dados para simulações no programa.

Nas demais métricas estudadas, Manhattan e Euclidiana, foi necessário preparar o arquivo da base de dados, eliminando os termos que apresentavam valores nulos para se obterem resultados satisfatórios.

Como as medições de curvas de carga têm grande probabilidade de não possuírem valores em determinados períodos, seja por problemas de medição, recuperação da massa de dados, erros de formatação e outros, esta métrica tornou-se a mais adequada, na medida em que minimiza o impacto da ausência de dados no conjunto.

\section{- Representatividade}

É definida como a relação entre o número de curvas de cada Cluster sobre o numero total de curvas do transformador. 


\subsection{Desenvolvimento do Algoritmo}

Com o objetivo de analisar as curvas de carga diárias, um algoritmo de Cluster foi implementado no pacote $\mathrm{R}$, em linguagem de programação $\mathrm{C}++$, como descrito a seguir.

\section{- Obtenção dos Dados}

Os dados de cada transformador são obtidos através de medições horárias de Potência Aparente (MVA) das subestações. Os dados são horários e a matriz de dados que é inserida no programa tem a dimensão 24 (horas) x 365 (dias).

O algoritmo identifica e carrega essa lista e, com isso, a análise é executada individualmente para todos os transformadores que compõem a lista.

Através do procedimento Clara, que será apresentado na seqüência, é escolhido o melhor número de clusters, separando assim as curvas entre os Clusters.

\subsubsection{Procedimento Clara}

O Clara é um procedimento interno e pré definido no software R que escolhe o melhor número de Clusters e divide as observações (vetores) de um conjunto de dados em grupos, através de uma determinada distância.

Quando se trata de um banco de dados com mais de 200 observações, o método "partition clustering" é bastante adequado.

O Clara é um procedimento interno de otimização que tem como objetivo escolher o melhor número de clusters. Ao final deste processo de otimização, o software apresenta um gráfico com vários vetores, sendo que o de maior tamanho indica o melhor número de clusters para aquele conjunto de dados. 


\subsubsection{Saída de Dados do Software $\mathbf{R}$}

Após o procedimento da Clara, que escolhe o melhor número de clusters a ser utilizado, o programa executa os cálculos da curva média $\pm 1,64$.

Ao assumirmos o valor de 1,64 6, teremos o valor de $90 \%$ para o intervalo de confiança, suficiente para os estudos de carregamento dos transformadores, razão pela qual foi escolhido no desenvolvimento do algoritmo.

\subsubsection{Critérios Adotados}

Após a execução dos cálculos, o software apresenta um gráfico contendo uma nuvem de curvas agrupadas em clusters, que variam entre 2 e 10. Neste gráfico serão apresentadas todas as curvas que compõem o cluster além dos valores das curvas médias $\pm 1,64 \sigma$.

Foram estudados aproximadamente 300 transformadores, sendo que em aproximadamente $70 \%$ dos casos as curvas foram agrupadas em 2 clusters, dividindo as curvas basicamente em dia de semana e finais de semana.

Todas as curvas características podem ser consideradas para as análises sob os mais variados aspectos. Neste trabalho o critério adotado foi escolher como curva característica da subestação aquela que causa maior perda de vida útil ao transformador, segundo a Lei de Arhenius, conforme apresentado em 2.4.2.

Além disso, tendo em vista que estamos estudando o carregamento do transformador, foi descartada a curva média decrescida de 1,64 $\sigma$.

$\mathrm{Na}$ seqüência do trabalho apresentaremos o teste da metodologia apresentada onde foram estudados os dados de dois transformadores e suas respectivas subestações.

\subsection{Teste da Metodologia}

Com a finalidade de teste e apresentação da metodologia estatística desenvolvida no software R, foi escolhida a SE Penápolis cujos dados são do ano de 2005. 
Através do procedimento Clara, descrito anteriormente, é obtido o gráfico mostrado na figura a seguir.

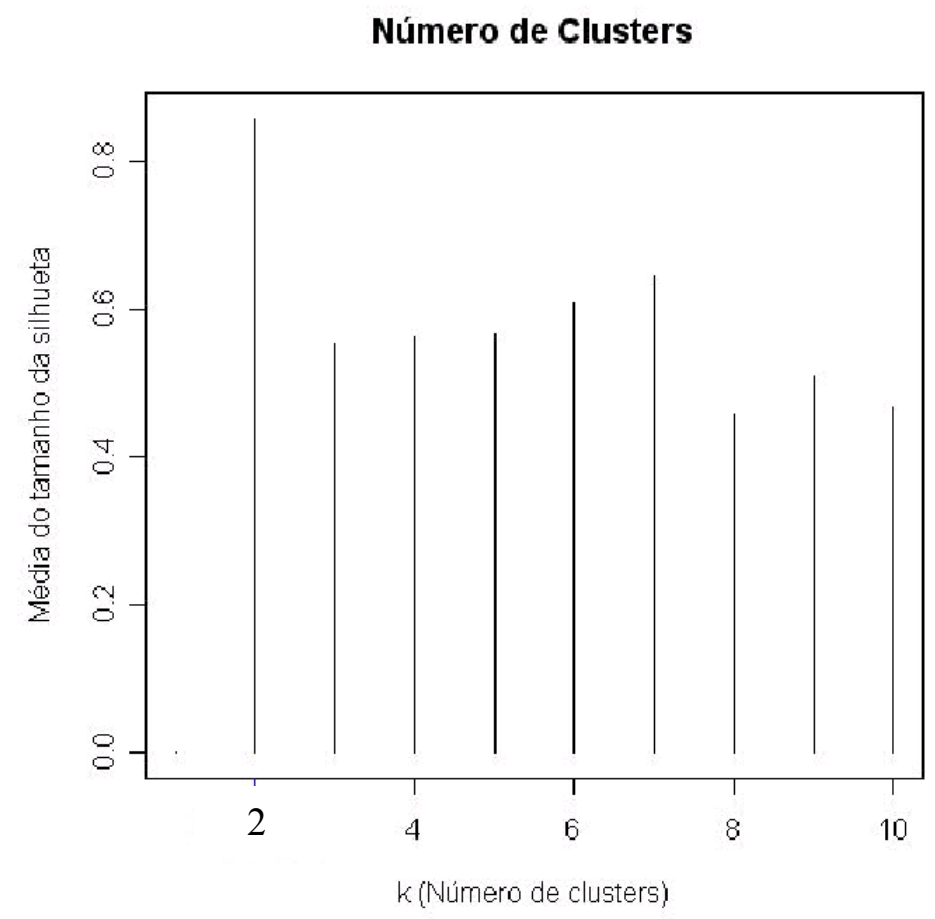

Figura 3.1 - Gráfico de resultados do Procedimento Clara.

$\mathrm{Na}$ figura mostrada anteriormente, a maior barra indica o melhor numero de clusters para o agrupamento destes dados, neste caso dois.

$\mathrm{Na}$ seqüência o software calcula os valores da média $\pm 1,64 \sigma$ que serão as respectivas curvas características de cada cluster.

A partir destes cálculos, são obtidos os gráficos dos dois clusters com as curvas de carga diárias e suas respectivas curvas médias $\pm 1,64 \sigma$. 

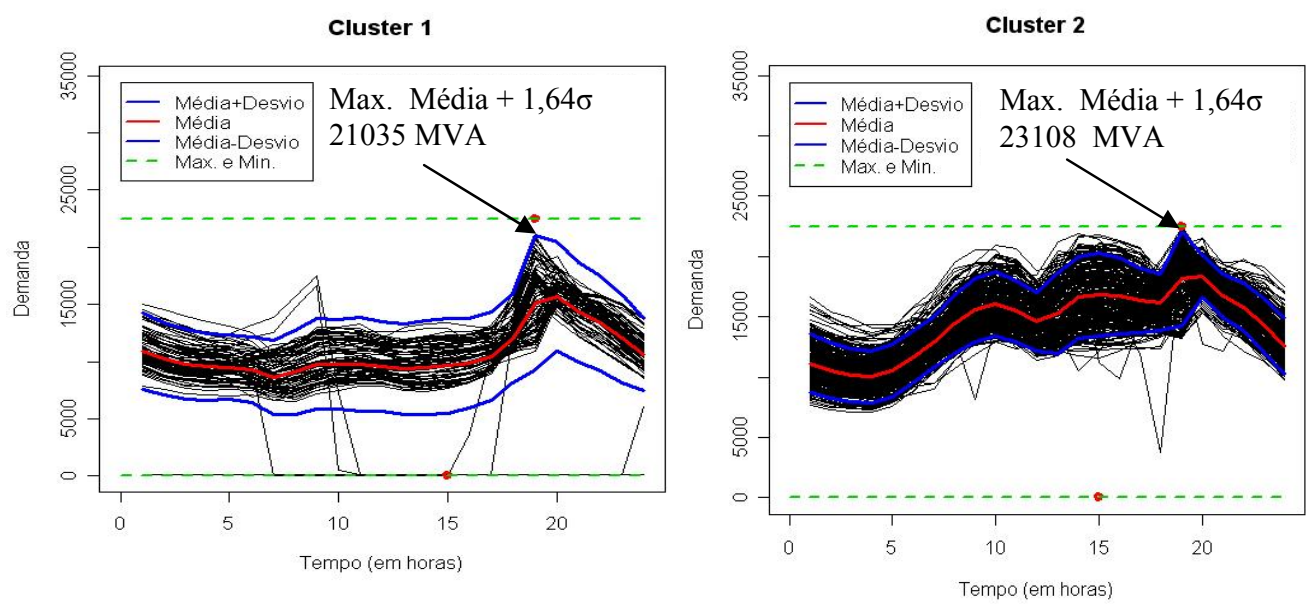

Figura 3.2 - Clusters com as curvas diárias - SE Penápolis.

A figura anterior mostra que o software dividiu as curvas em 2 grupos, sendo que aproximadamente $77 \%$ destas encontram-se no cluster 2 . Em uma primeira análise, é razoável considerar que o grupo que tem o maior número de curvas representa os dias de semana e o menor os finais de semana. Como já citado anteriormente, esta situação ocorreu em aproximadamente $70 \%$ dos casos estudados de transformadores.

Dando seqüência à análise, o software também apresenta os gráficos com os valores da média e mediana de cada cluster, além de apresentar a curva com maior valor pontual de demanda.
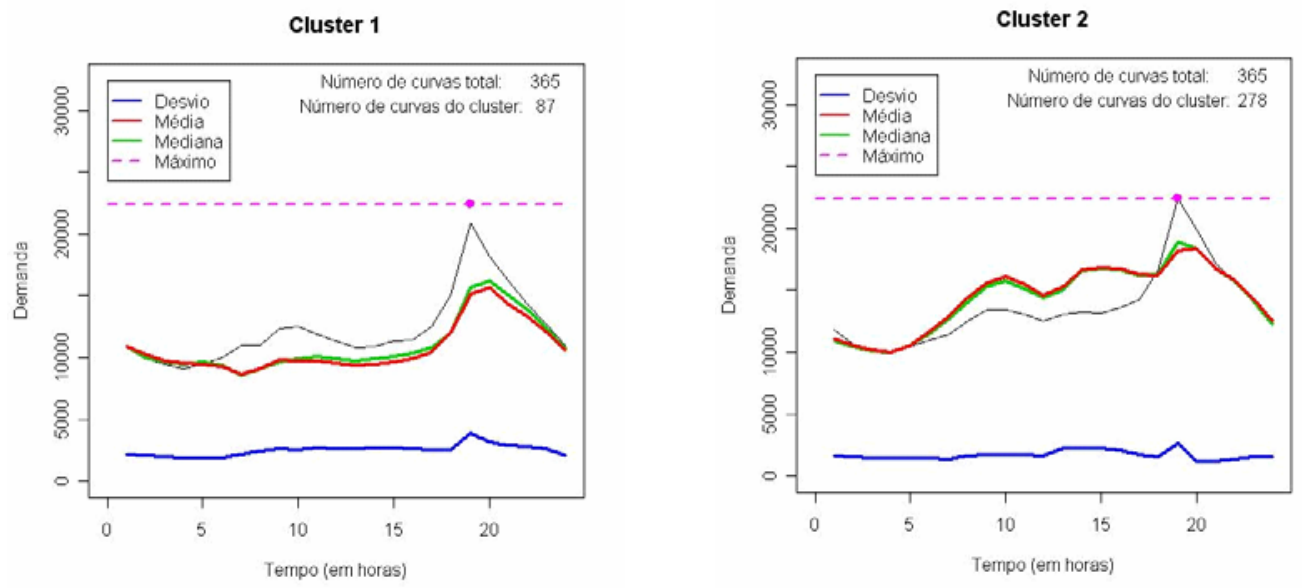

Figura 3.3 - Curvas da Média e Mediana - SE Penápolis. 
Em ambos os clusters, a curva da média está praticamente superposta com a curva da mediana, mostrando que os dados têm o comportamento de uma distribuição normal.

A figura a seguir mostra uma saída adicional do software, que é a representatividade de cada clusters em relação à quantidade total de curvas analisadas.

\section{Representatividade da Demanda Máxima no Ano}

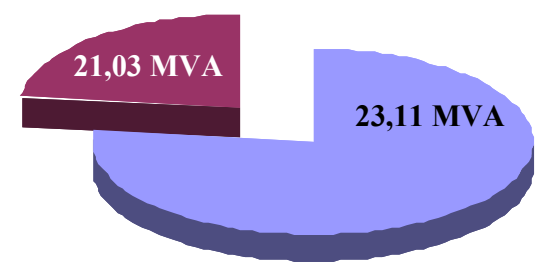

Figura 3.4 - Gráfico de Representatividade da Demanda Máxima - SE Penápolis.

Para cada valor de demanda máxima apresentada na figura anterior, há uma curva de carga característica, composta pela média $+1,64 \sigma$. Através destas curvas é razoável considerarmos sua representatividade em relação ao carregamento do transformador, ao longo do ano.

No estudo de caso do capítulo 5, com base nestas curvas características, calcularemos o carregamento máximo admissível e perda de vida para o transformador em ambas as situações, dando subsídios para uma tomada de decisão.

A figura a seguir mostra as duas curvas características da SE Penápolis, obtidas através do SGT, utilizadas no estudo de caso. 


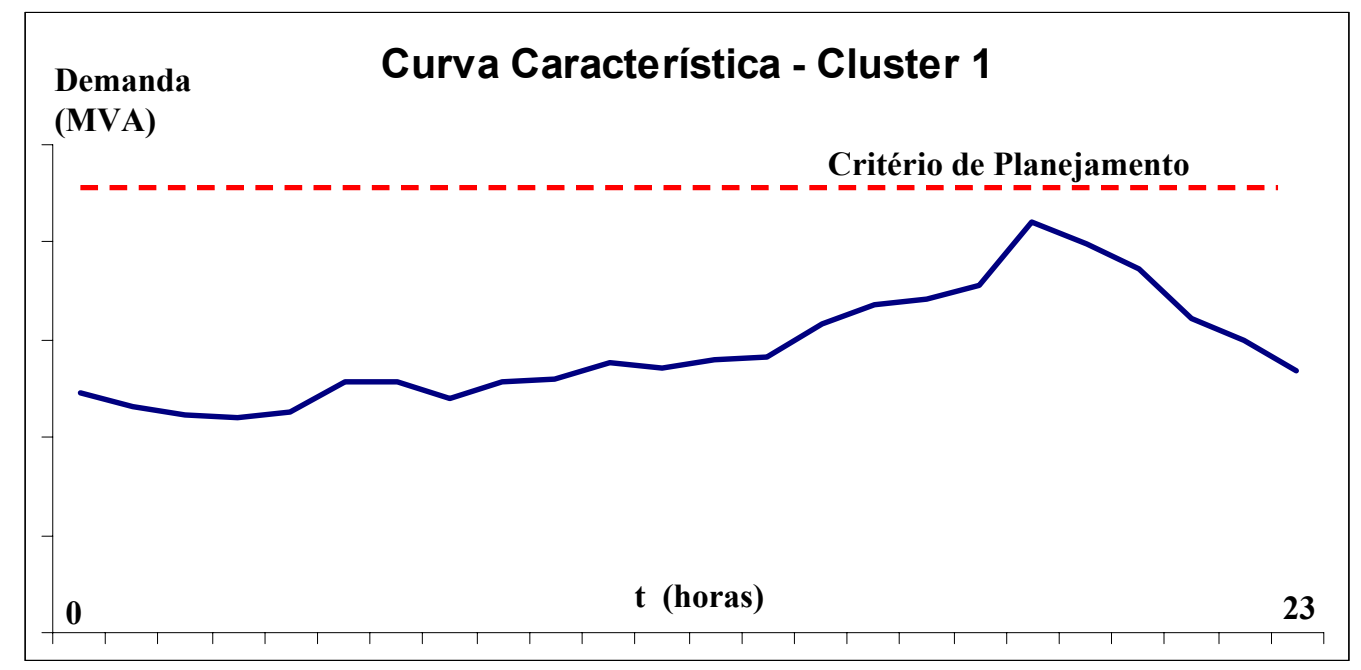

Figura 3.5 - Curva Característica - SE Penápolis (Cluster 1)

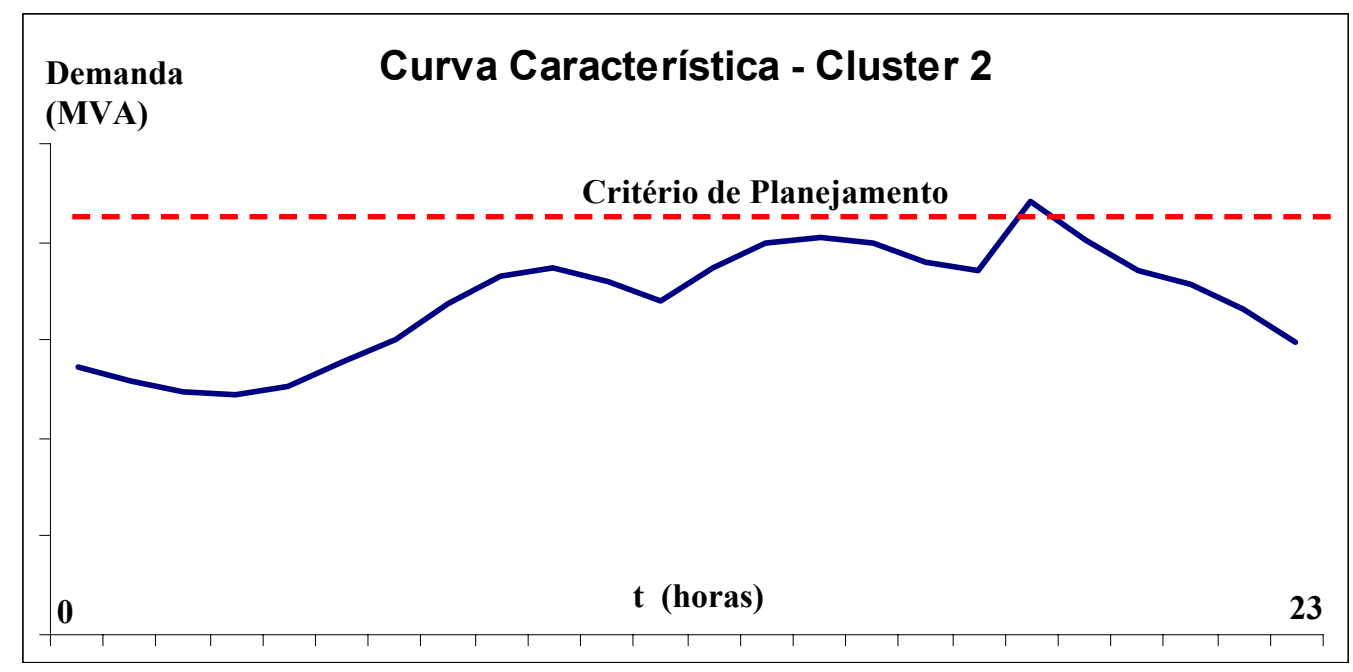

Figura 3.6 - Curva Característica - SE Penápolis (Cluster 2) 


\section{CAPÍTULO 4 - Desenvolvimento do Sistema Integrado}

\subsection{Sistema de Gestão de Transformadores (SGT)}

O sistema SGT é um software que agrupa de maneira ordenada todas as informações de um grupo de transformadores em um banco de dados interativo, disponibilizando todo tipo de informação necessária para os setores de Engenharia de Manutenção, Operação e Planejamento executarem a gestão deste ativo.

Além disso, o SGT também se configura como uma ferramenta de apoio a tomada de decisões em relação a estes equipamentos.

O sistema foi concebido na linguagem Visual Basic 6.0 sendo o processo de impressão realizado em forma de relatórios internos ao sistema, ou exportados para uma planilha eletrônica.

A implantação deve ser feita em um microcomputador que possua no mínimo a seguinte configuração: Pentium 166, espaço livre de $27 \mathrm{Mb}$ Sistema Operacional Windows 95 ou superior.

Quando se tem uma grande quantidade de transformadores, como é o caso das concessionárias de energia ou grandes empresas, a implantação de um sistema de monitoramento para cada transformador é muito onerosa e inviável sob o ponto de vista econômico.

Em contrapartida é extremamente necessário que se tenham todas as informações referentes aos transformadores para se agir rapidamente em situações de emergência.

A finalidade do SGT é exatamente essa, fornecer dados de forma segura e ágil para as áreas responsáveis pela gestão dos transformadores.

Por ser tratar de um banco de dados o custo será bem inferior se comparado a um sistema de monitoramento. Assim sendo, podemos ter no SGT todos os transformadores de acordo com a nossa escolha ou necessidade. 
A figura a seguir mostra o conceito de gerenciamento integrado, onde o SGT é a fonte comum de consultas para todas as áreas envolvidas na gestão do transformador além de promover a interação entre elas.

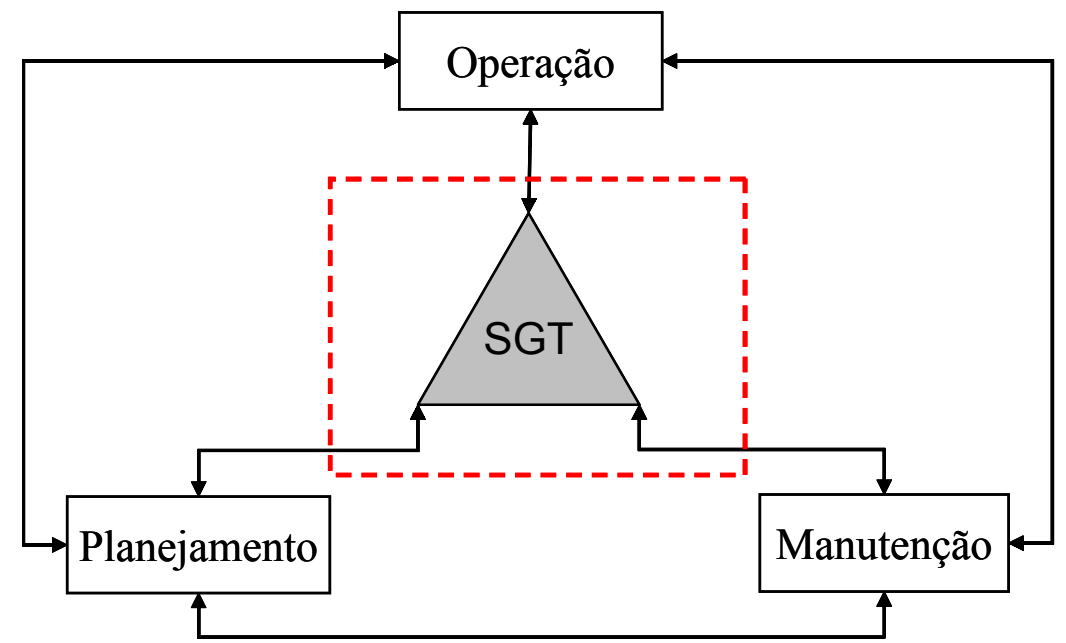

Figura 4.1 - Conceito de Gerenciamento Integrado do Transformador

\subsection{Gerenciamento dos Ensaios de Óleo Isolante}

Um controle manual dos dados resultantes das análises em óleo isolante exige muitas horas de dedicação e mesmo assim pode resultar em falhas, tais como um esquecimento de atualização dos dados, perda de um documento importante, bem como o procedimento pode apresentar muitas dificuldades, como a atualização de várias fichas de controle, demora para obter uma determinada informação, etc.

Após a entrada dos dados é possível processar os diagnósticos de forma instantânea, apresentando possíveis causas de defeito ou falhas em andamento, bem como impressão de relatórios e gráficos correspondentes à curvas de tendência ou situação atual, sendo utilizado como subsídio para decisões relacionadas ao equipamento analisado.

Devido à importância destes dados para o gerenciamento das condições dos transformadores e ao grande volume de resultados de ensaios de óleo isolante efetuados ao longo dos anos, assim como a conveniência de uma ferramenta de manutenção preditiva, tornou-se necessário o desenvolvimento de um módulo do 
SGT que execute diagnósticos automáticos, de modo que os resultados sirvam de apoio às atividades de manutenção, operação e planejamento.

Em 2.3.2 são apresentadas técnicas de interpretação de análises cromatográficas que serviram de base para o desenvolvimento dos algoritmos de análise.

O módulo das análises cromatográficas é o mais complexo, pois não existem valores limites de comparação e sim relações que foram obtidas de estudos realizados por especialistas neste assunto, em anos de pesquisa de casos reais, e por este motivo a presença de um profissional ainda é muito importante para a tomada final da decisão.

Além do módulo de cromatografia gasosa o SGT contém mais 3 módulos que foram desenvolvidos com base nas informações apresentadas no capítulo 2 deste trabalho e serão apresentados com mais detalhes a seguir.

\subsection{Módulos do SGT}

Os módulos do SGT foram criados para facilitar a obtenção e a manipulação dos dados, bem como facilitar a visualização dos resultados pelo usuário e fornecer de modo imediato informações vitais ao gerenciamento dos equipamentos imersos em óleo.

O SGT foi dividido em quatro módulos distintos, sendo:

- Processamento dos dados das análises cromatográficas;

- Processamento das análises físico-químicas;

- Dados técnicos e Manutenção dos Transformadores;

- Cálculo do Carregamento Máximo Admissível dos Transformadores.

Os módulos de processamento de dados das análises físico-químicas e cromatográficas são alimentados semestralmente com uma carga de dados composta por resultados de ensaios de óleo isolante efetuados pelo laboratório. 
A cada carga semestral de dados nos módulos de processamento de análises cromatográficas e físico-químicas, o SGT executa uma rotina interna que fará a análise dos dados para a emissão dos respectivos diagnósticos.

O módulo de controle dos dados técnicos dos equipamentos e subestações é alimentado e atualizado de forma manual sempre que ocorre alteração nos equipamentos das subestações.

O módulo de carregamento máximo admissível dos transformadores executa os cálculos e simulações com base numa curva de carga obtida pelo método estatístico apresentado no capítulo 3 deste trabalho.

Conforme apresentado no capítulo 3, a metodologia utilizada para a escolha da curva característica da subestação é a de "Clusters", a partir das 365 curvas de carga horárias de uma subestação, com a qual obtemos uma curva característica da carga alimentada pelo transformador no ano de estudo.

A obtenção da curva é obtida por meio do software "R" que faz vários tipos de análises estatísticas e está acoplado ao SGT. A figura a seguir mostra a tela do Módulo de Carregamento Máximo Admissível e Perda de Vida do SGT.

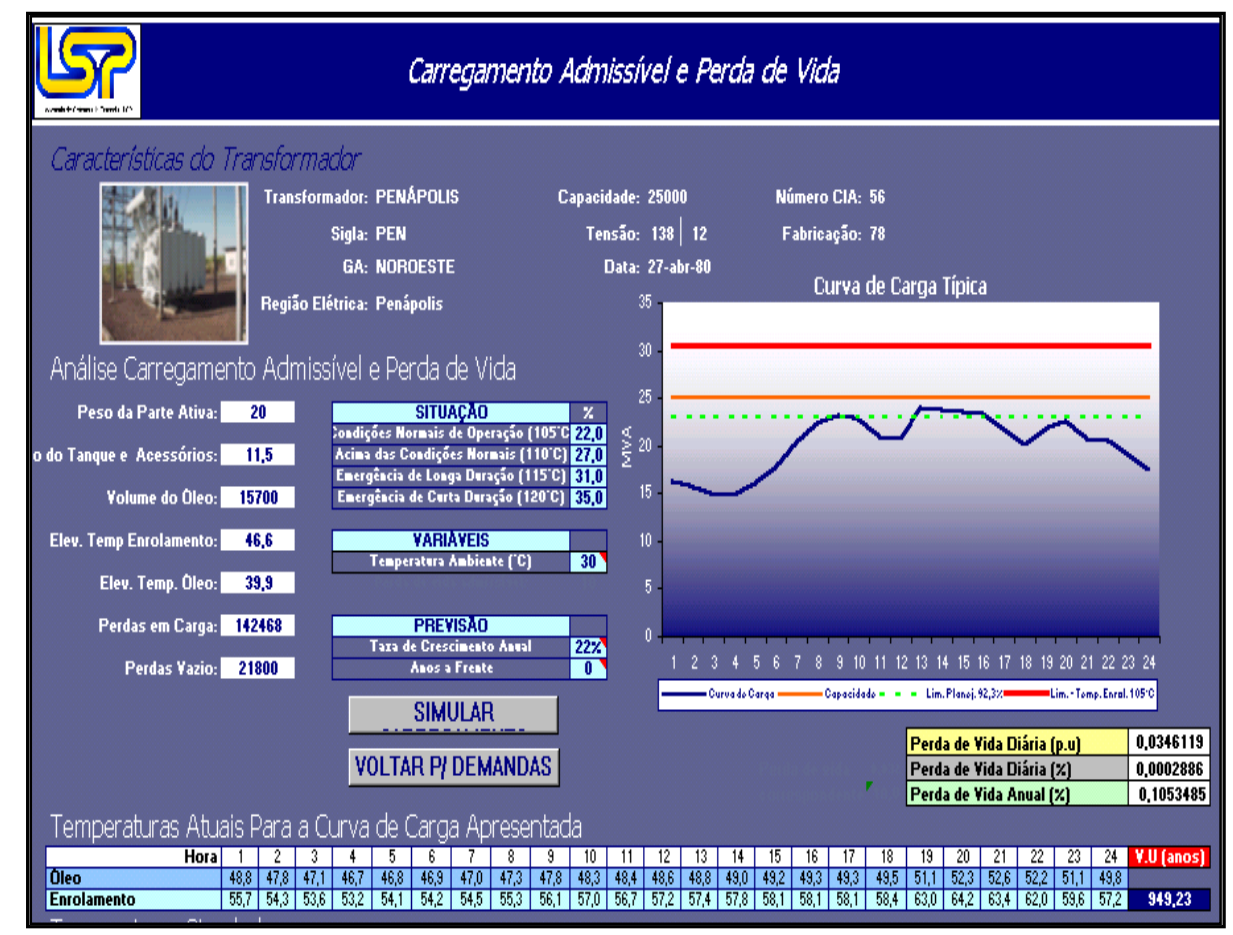

Figura 4.2 - Tela do Módulo de Carregamento Máximo Admissível e Perda de Vida. 
O diagrama de blocos apresentado na figura 4.2 a seguir mostra um panorama geral do SGT e suas principais funcionalidades.

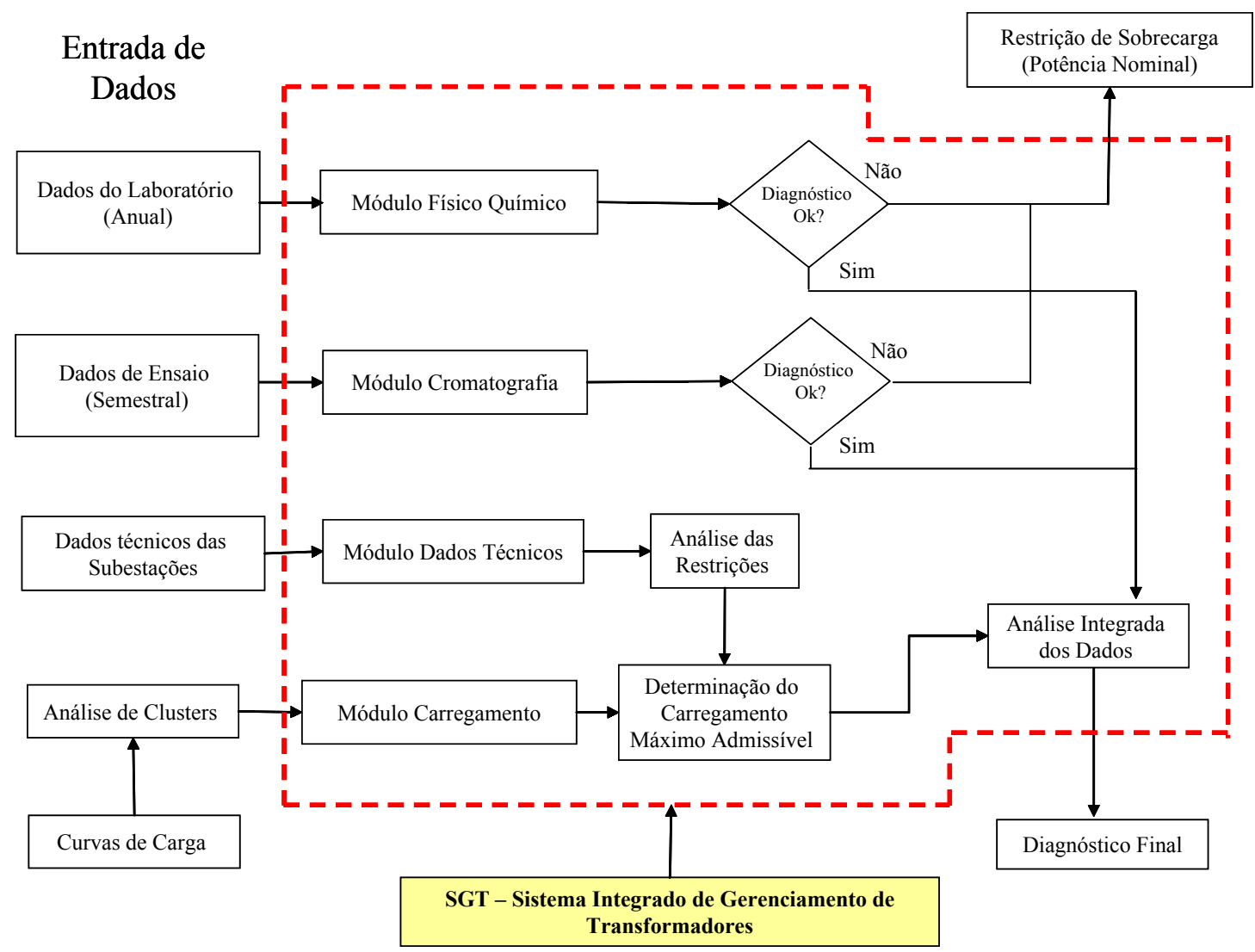

Figura 4.3 - Diagrama de Blocos do Sistema Integrado - SGT

\subsubsection{Processamento dos dados das Análises Cromatográficas}

No módulo de processamento dos dados das análises cromatográficas, destacam-se as interfaces de cadastro, consultas e diagnósticos dos dados destas análises, segundo as normas nacionais e internacionais vigentes.

Como já citado e descrito em 2.3.2, essa interpretação é de maior complexidade e a tomada de decisão deve ser feita por um profissional que tenha conhecimentos sobre o comportamento e evolução dos gases gerados em equipamentos elétricos. 
O diagnóstico das análises cromatográficas é feito através dos algoritmos desenvolvidos para este fim, a partir da carga de dados recebida do laboratório responsável pelos ensaios de óleo dos transformadores e equipamentos em geral. A figura a seguir mostra o roteiro de processamento das análises cromatográficas no Sistema Integrado.

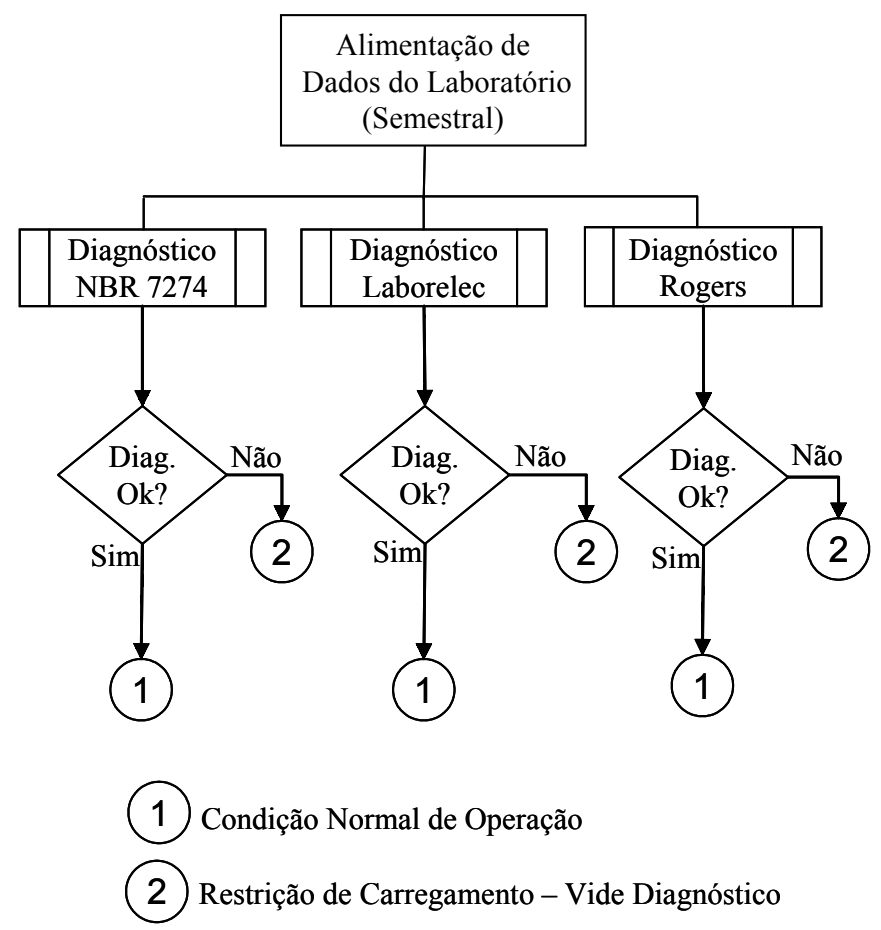

Figura 4.4 - Diagrama de Blocos - Processamento Cromatografia

O diagrama de blocos da figura 4.2 mostra como o SGT faz o processamento das análises cromatográficas do óleo isolante. A partir de uma alimentação de dados de ensaios recebidos do laboratório, o SGT faz uma análise e fornece os respectivos diagnósticos através dos algoritmos desenvolvidos para cada norma.

A alimentação de dados é feita por meio de um arquivo de banco de dados em formato MS Access e o processamento completo de 500 equipamentos leva por volta de 20 minutos.

Após o processamento dos dados, o usuário pode fazer uma consulta dos transformadores que se encontram com algum tipo de restrição segundo os diagnósticos gerados. 
O SGT fornece também uma lista dos transformadores que apresentaram algum tipo de restrição e, portanto, não devem operar acima de suas capacidades nominais por questões de segurança.

Através do SGT é possível comparar vários diagnósticos para a tomada de decisão, já que a interpretação das análises cromatográficas nem sempre é uma tarefa tão simples.

\section{- Cadastro de Amostras}

A interface de cadastro de amostras é a responsável pela inserção dos dados das amostras cromatográficas no banco de dados. Para fazer a inclusão de uma amostra de forma manual no banco de dados, seleciona-se o equipamento através de seus dados técnicos ou através da subestação onde se encontra.

Além do cadastro individual de cada amostra também pode ser feita a alimentação de dados de uma só vez. Essa atualização de dados em geral é feita semestralmente, periodicidade adotada por grande parte das empresas para a realização dos ensaios de cromatografia gasosa.

\section{- Diagnósticos}

A interface de diagnóstico é a responsável por mostrar ao usuário as possíveis falhas ou principio destas e é baseada nas normas brasileiras e demais critérios internacionais de diagnósticos utilizados na atualidade. Os diagnósticos são realizados com as duas últimas amostras cadastradas no banco de dados e fornece as seguintes informações:

- Valores de referência para cada gás em ppm;

- Ensaio anterior;

- Ensaio atual;

- Taxa de variação mensal em \%;

- Teor de Concentração dos gases;

- Visualização gráfica dos gases combustíveis;

- Relação entre gases. 
$\mathrm{Na}$ interface de diagnóstico tem-se ainda a possibilidade de comparar graficamente os dados obtidos das análises das amostras com gráficos padrões da norma NBR-7274/82 [11], além de podermos fazer comparações com dois outros métodos apresentados em 2.3.2.

Vários são os critérios adotados mundialmente para diagnóstico de transformadores, sendo que para cada diagnóstico é tomada e implementada uma decisão, tais como: retirada de operação para investigação, redução de tempo para amostragem, restrição de carga, etc.

As bases para a elaboração dos diagnósticos são as seguintes normas:

- IEC e NBR 7274/82 - Relação entre gases [11] e [30] ;

- ROGERS - Relação entre gases; [13] e [14] ;

- LABORELEC - Composição e Relação entre gases [15] e [16].

Com base nas informações obtidas dos cálculos das relações são emitidos alertas da situação encontrada para cada critério de diagnóstico. Essas informações são fundamentais para as Áreas de Engenharia de Manutenção que têm condições de concluir um diagnóstico mais detalhado da situação encontrada.

\section{- Visualização Gráfica da Evolução dos Gases}

A visualização gráfica da evolução dos gases é um recurso muito importante do sistema, mostrando ou cada gás em particular ou seleções simultâneas de vários gases. Na cromatografia gasosa é mais importante analisar a evolução dos gases ao longo do tempo do que os valores em si. 


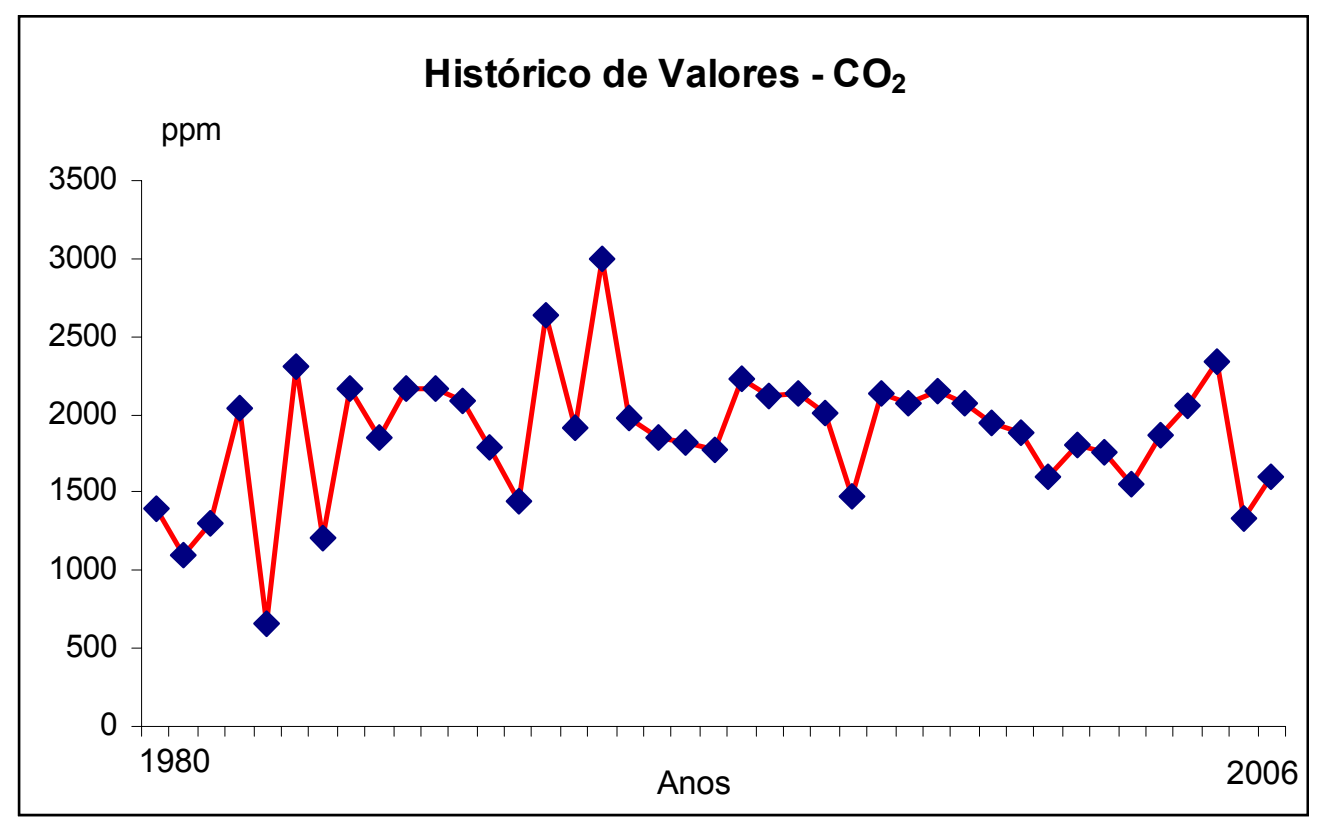

Figura 4.5 - Gráfico de evolução de Gases - Dióxido de Carbono $\left(\mathrm{CO}_{2}\right)$

O gráfico é traçado de acordo com as informações contidas no histórico e essa visualização é uma importante ferramenta de análise, já que é possível identificar o início da evolução e suas conseqüências ao transformador.

Outro ponto positivo da interface gráfica é a possibilidades da obtenção de várias informações, tais como o cálculo da taxa de evolução dos gases, projeções é realizadas através de regressão linear ou quadrática, e análise conjunta de gases correlacionados comparando seus comportamentos, e obter estatísticas que ajudarão nas tomadas de decisões.

A visualização é dividida em dois grupos distintos que são os gases combustíveis (Hidrogênio, Monóxido de Carbono, Metano, Etileno, Etano e Acetileno), que informam a presença de alguma anomalia interna ao equipamento, e o grupo formado pelos gases não combustíveis (Dióxido de carbono, Oxigênio).

\subsubsection{Processamento das Análises físico-químicas}

O módulo de processamento das análises físico-químicas é o responsável pelo fornecimento de informações sobre o estado físico do óleo e como conseqüência, 
pelo tipo de intervenção que deve ser realizada no óleo, para que este retorne às suas características próximas das originais.

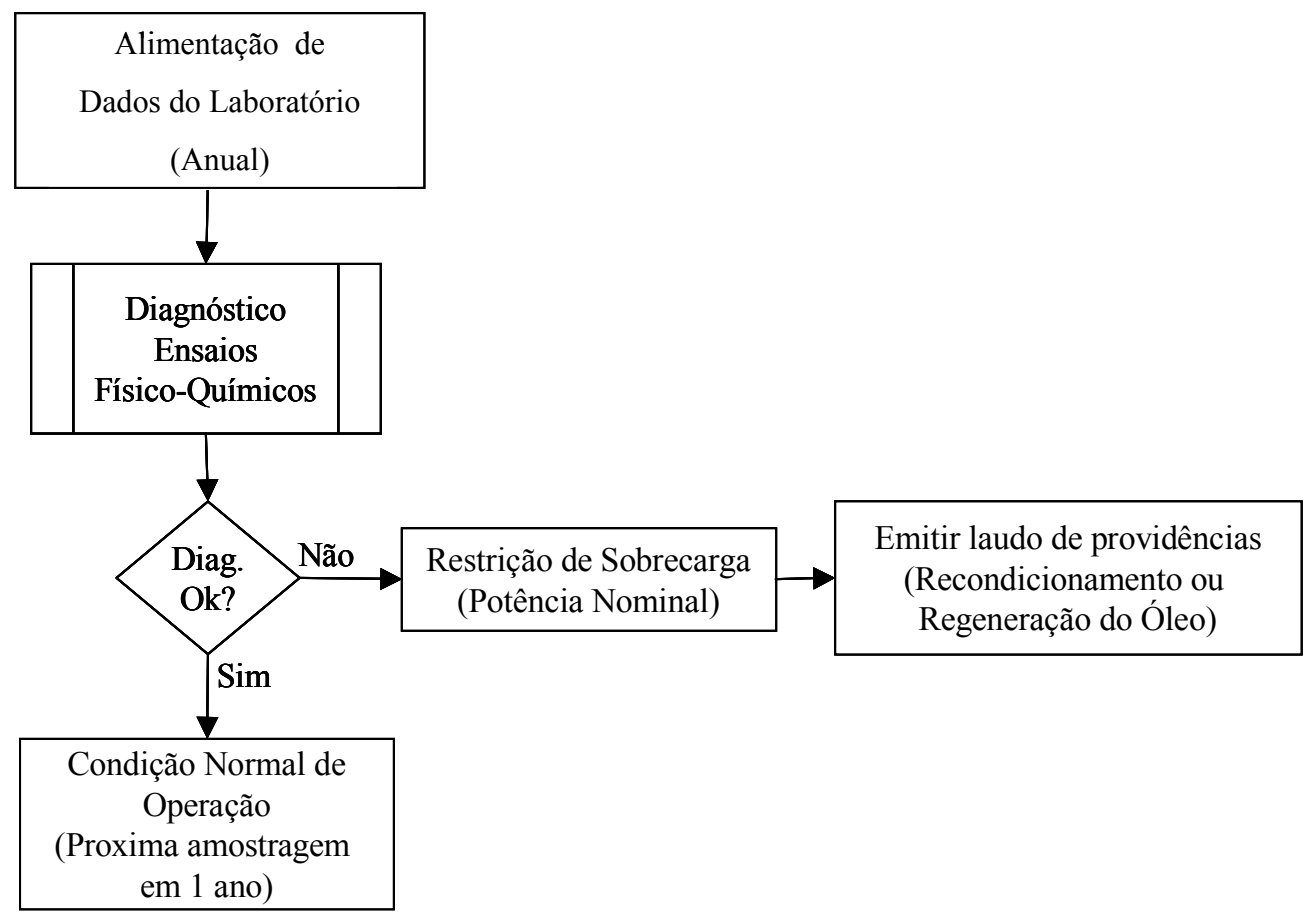

Figura 4.6 - Diagrama de Blocos - Processamento das Análises Físico-Químicas.

A interpretação das análises físico-químicas é mais simples, pois existem valores limites normalizados e por este motivo, o laudo já é gerado automaticamente pelo sistema, não precisando de intervenção humana.

Por se tratar de um processamento mais simples, o sistema restringe automaticamente a operação do equipamento, bem como indica a necessidade de recondicionamento ou regeneração do óleo isolante, de acordo com o comportamento de cada equipamento.

Utilizamos a regeneração para reconstituição dos níveis de acidez, tensão interfacial, fator de dissipação e cor, enquanto que utilizamos o recondicionamento do óleo isolante para reconstituição das características de rigidez dielétrica e teor de água do óleo. 


\section{- Cadastro das amostras físico-químicas}

$\mathrm{O}$ cadastro das amostras físico-químicas permite ao usuário cadastrar de forma manual todos dados obtidos de um ensaio físico-químico completo de um transformador, regulador ou comutador sob carga.

Os mesmos cuidados tomados no cadastro das análises cromatográficas devem ser tomados no cadastro das amostras físico-químicas.

\section{- Consulta das amostras físico-químicas}

A interface de consulta de amostras físico-químicas é bem similar à interface de cadastro das amostras cromatográficas, possibilitando a consulta dos dados de cadastrados de um determinado equipamento.

A consulta do histórico nesta interface também é de fundamental importância, uma vez que é através destas análises que são feitos o devido diagnóstico.

As consultas podem ser feitas diretamente na tela do computador ou através de relatórios, que podem ser impressos, ou visualizados na tela.

A cada intervenção realizada no óleo isolante do equipamento é retirada uma amostra e enviada a um laboratório cujos dados são cadastrados no sistema.

Estes dados auxiliam na elaboração de planos com a finalidade de evitar acidentes ambientais.

\section{- Unidades com necessidade de intervenção no óleo}

A interface fornece a relação de equipamentos que devem ter o óleo isolante recondicionando ou regenerado.

O tipo de intervenção no óleo é determinado pelas suas características físicas e químicas. Nesta interface as decisões são feitas automaticamente pelo sistema que elabora a lista com a relação dos equipamentos. De acordo com os dados das análises físico-químicas. 
Uma outra interface permite a priorização de intervenção do óleo destes equipamentos, pois fornece o tempo em que determinada propriedade está com sua característica físico-químicas fora dos valores limites.

\section{- Transformadores com restrição}

Como as amostras são realizadas em tempos determinados (cromatografia semestral e físico-químico anual), toda vez que ocorre o carregamento destes valores no banco de dados do sistema, é necessário que o usuário solicite ao sistema a realização destes diagnósticos. Para este processamento, algumas tabelas do banco de dados são atualizadas, e são exatamente nelas onde ocorrem as consultas do sistema.

Os cálculos são simples, porém demorados, pois todos os resultados vêm de tabelas normalizadas de acordo com os métodos descritos em 2.3.2. Para uma pequena quantidade de análises seria fácil, mas para mais de 500 equipamentos se tornaria algo bem complexo.

Neste caso o SGT é de fundamental importância já que muitas vezes não basta termos somente os valores obtidos das normas, sendo necessário observarmos os históricos, taxas de variação, ou seja, são milhares de dados a serem analisados.

As listagens extraídas do SGT, contendo os equipamentos que não devem operar em sobrecarga, podem ser passadas ao setor de controle da carga do sistema, responsável pelo monitoramento, controle e despacho do sistema de distribuição de energia elétrica.

Através do SGT é possível fazermos um estudo minucioso em todos os dados das análises de óleo do equipamento e compararmos com outros equipamentos similares, (mesma família), melhorando a qualidade do diagnóstico.

Uma ação sugerida automaticamente pelo SGT é a redução do intervalo de amostragem, passando para trimestral, bimensal, mensal, quinzenal ou até mesmo semanal. Essa ação tem a finalidade de colocar o equipamento num regime diferenciado de acompanhamento visando identificar a real gravidade do problema detectado pela amostragem do óleo isolante. 


\subsubsection{Dados Técnicos e Manutenção dos Transformadores}

Neste módulo estão contempladas as informações referentes à manutenção dos transformadores bem como o seu histórico de ocorrências. O Plano de Manutenção Preventiva de um Transformador de Potência pode varia muito de empresa para empresa, porém, é extremamente necessário que de tempos em tempos se desligue o equipamento para se fazer uma verificação detalhada.

Dentro do módulo de manutenção do SGT é possível inserirmos o Plano de Manutenção dos Transformadores, além de fazermos o acompanhamento das atividades realizadas gerando um histórico de informações.

Além das informações dos transformadores, nesse módulo também é possível inserirmos informações referentes à manutenção dos comutadores sob carga instalados nos transformadores.

O controle de manutenção dos comutadores é de fundamental importância para a operação confiável dos transformadores, já que estudos apontam que tais dispositivos respondem por parte considerável das falhas dos transformadores. [1], [17] e [25].

A necessidade de manutenção de um comutador sob carga geralmente se dá de duas formas, por tempo ou pelo número de operações. Assim sendo, cada equipamento tem um plano de manutenção específico de acordo com cada fabricante.

Tendo em vista a diversidade de informações e planos de manutenção, a inclusão dos planos no módulo de manutenção do SGT facilita o gerenciamento da manutenção dos comutadores sob carga.

Além de informações referentes à manutenção e ao desempenho em geral dos comutadores sob carga, através do SGT é possível controlarmos as futuras datas de manutenção preventiva.

Esse controle pode ser feito com a atualização do número de operações dos comutadores e data da última manutenção. 
Neste módulo do SGT há uma rotina interna que identifica no plano de manutenção do comutador sob carga o que ocorre primeiramente, número de operações ou tempo. Uma vez alcançada uma das premissas de manutenção o sistema emite um alerta ao usuário a respeito da necessidade de manutenção do equipamento.

Mensalmente o número de operação dos comutadores é atualizado e o sistema compara os dados inseridos com a leitura anterior fazendo a diferença entre elas. Além disso, o sistema faz uma projeção da próxima data de manutenção com base na média de operações no mês.

Esse cálculo é somente uma referência e pode servir de base para programações futuras de desligamento do transformador para execução dos serviços de manutenção dos comutadores sob carga.

Em uma subestação, nem sempre o transformador é o limitante de carregamento. Neste módulo do SGT são identificados os possíveis pontos de restrição de carregamento da subestação, cujos dados são inseridos automaticamente no módulo de carregamento máximo admissível para determinação dos patamares de carregamento da subestação.

Outra funcionalidade deste módulo é possibilidade de agrupamento dos transformadores por tipo, modelo, fabricante, idade, etc. Essa funcionalidade do SGT auxilia na análise integrada dos dados, sobretudo das análises cromatográficas já que algumas famílias de transformadores geram certas quantidades características de gases no óleo isolante.

A análise dos dados técnicos das subestações agiliza na tomada de decisões quanto a obras, patamares de sobrecarga, tipologia dos equipamentos, etc.

\subsubsection{Cálculo do Carregamento Máximo Admissível dos} Transformadores

De acordo com a norma de carregamento de transformadores de potência NBR-5416/97 [11], um transformador de potência pode operar acima das condições nominais por certos períodos sem prejuízo de sua vida útil. 
Certamente, tais condições dependem de uma série de aspectos como condição do óleo isolante, manutenção, histórico de falhas, etc.

Este módulo do SGT é responsável pelos cálculos do carregamento máximo admissível dos transformadores de acordo com as premissas expostas em 2.14 utilizando as equações da NBR 5416/97 [11].

O cálculo do carregamento máximo admissível é feito com base na curva de carga obtida através do método estatístico apresentado no capítulo 3 seguindo a metodologia apresentada no diagrama de blocos da figura a seguir.

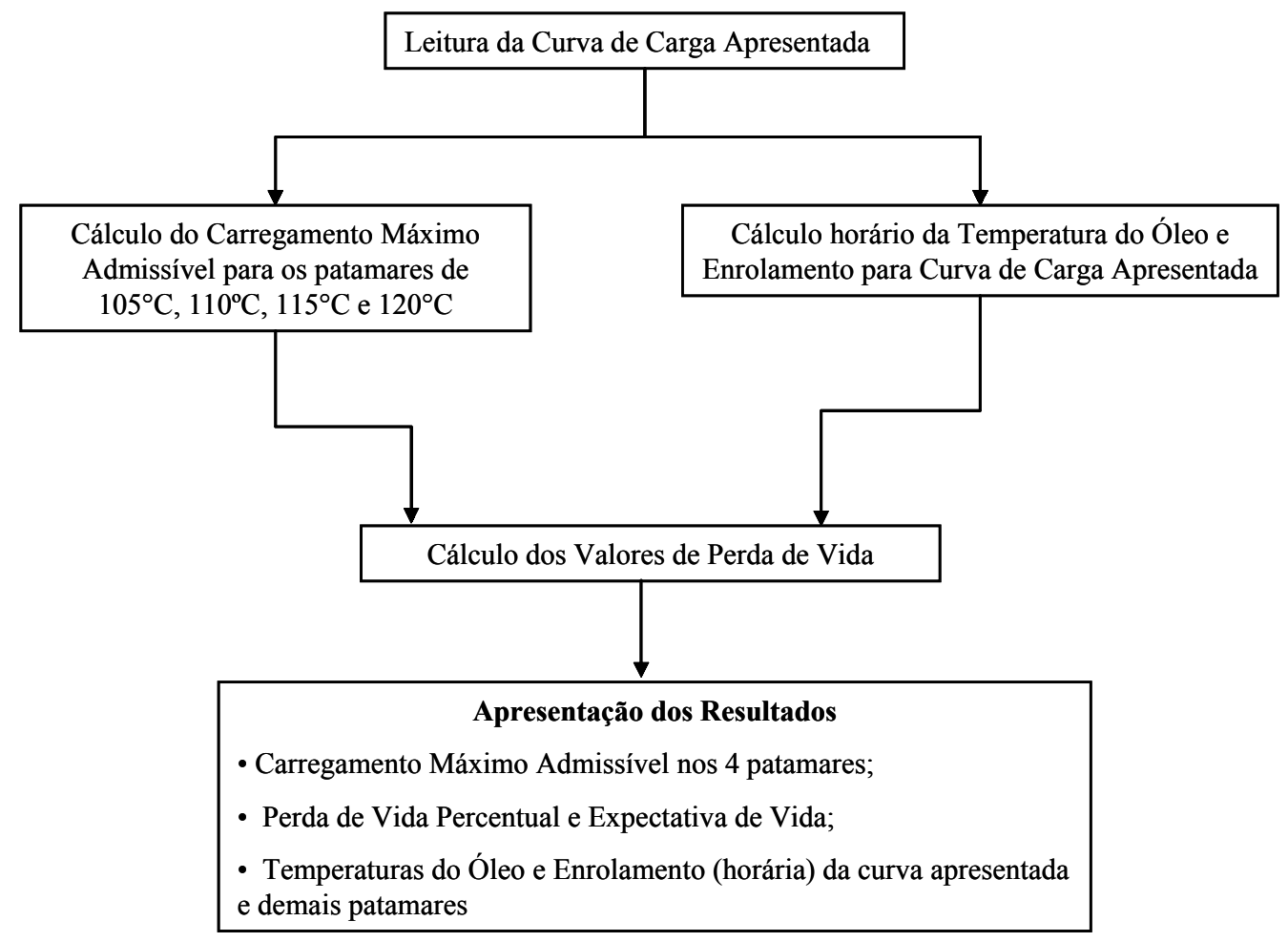

Figura 4.7 - Diagrama de Blocos do Módulo de Cálculo do Carregamento Máximo Admissível do SGT.

A curva de carga característica, obtida através do método estatístico apresentado no capítulo 3, é inserida no Módulo de Carregamento do SGT que já contém os dados técnicos dos transformadores. 
Com base nos dados técnicos do transformador e no valor de temperatura ambiente, inserido pelo usuário, o SGT fará os cálculos dos patamares de carregamento máximo admissível do transformador para a referida curva de carga e temperatura ambiente.

A simulação e cálculo de aquecimento do transformador são feitos com base na curva de carga característica utilizando o equacionamento proposto em [26] e desenvolvido com base na NBR-5416/97 [11].

O equacionamento inserido no módulo de Carregamento Máximo Admissível está apresentado a seguir e foi desenvolvido com base na NBR-5416/97 [11] e [49].

$$
K_{(j-1)}=\frac{S_{(j-1)}}{S_{n o m}}
$$

$\delta o=\Delta \theta o n\left[\frac{R K_{(j-1)}^{2}+1}{R+1}\right]^{n}$

$\theta o_{(j)}=\left[\delta o-\theta o_{(j-1)}+\theta a_{(j-1)}\right]\left(1-e^{\frac{-t}{\tau_{o}}}\right)+\theta o_{(j-1)}-\theta a_{(j-1)}+\theta a_{(j)}$

$\delta e=\Delta \theta e_{n} K_{(\mathrm{j}-1)}^{2 m}$

$\theta e_{(j)}=\left[\delta e-\theta e_{(j-1)}+\theta o_{(j-1)}\right]\left(1-e^{\frac{-t}{\tau_{e}}}\right)+\theta e_{(j-1)}-\theta o_{(j-1)}+\theta o_{(j)}$

Onde:

$\theta o_{(j)}$ - Temperatura do topo do óleo no instante de tempo j $\left({ }^{\circ} \mathrm{C}\right)$;

$\theta o_{(j-1)}$ - Temperatura do topo do óleo no instante de tempo j-1 $\left({ }^{\circ} \mathrm{C}\right)$;

$\theta e_{(j)}$ - Temperatura do ponto quente do enrolamento no instante de tempo $\mathrm{j}\left({ }^{\circ} \mathrm{C}\right)$;

$\theta e_{(j-1)}$ - Temperatura do ponto quente do enrolamento no instante de tempo j-1 $\left({ }^{\circ} \mathrm{C}\right)$; 
$\theta a_{(j)}$ - Temperatura ambiente no instante de tempo $\mathrm{j}\left({ }^{\circ} \mathrm{C}\right)$;

$\theta o_{(j)}$ - Temperatura ambiente no instante de tempo j-1 $\left({ }^{\circ} \mathrm{C}\right)$;

$S_{(j-1)}$ - Carregamento do transformador no instante j-1 (MVA);

$S_{\text {nom }}$ - Potência nominal do transformador (MVA);

$t$ - Intervalo de tempo entre aquisições sucessivas (horas);

$\Delta \theta o n$ - Elevação de temperatura do topo do óleo sobre a temperatura ambiente sob carregamento nominal $\left({ }^{\circ} \mathrm{C}\right)$;

$\tau_{o}$ - Constante de tempo térmica do transformador,para qualquer carga e para

qualquer diferença de temperatura, entre a elevação final e a inicial do topo do óleo (horas);

$R$ - Relação entre as perdas sob carga sob carga nominal e em vazio;

$n$ - Expoente utilizado para o cálculo da elevação de temperatura;

$\Delta \theta o n$ - Elevação de temperatura do ponto quente do enrolamento sobre a

temperatura do topo do óleo com carregamento nominal $\left({ }^{\circ} \mathrm{C}\right)$;

$\tau_{e}$ - Constante de tempo térmica do enrolamento do transformador (horas).

Com base na curva característica inserida no sistema, primeiramente são feitos os cálculos do valor de temperatura do óleo e do enrolamento.

A partir desta referência, o sistema aplica um percentual de sobrecarga limitado a 1,5 p.u e calcula os valores máximos de temperatura do óleo e enrolamento.

Caso a sobrecarga de 1,5 p.u ultrapasse o valor de temperatura limite, são aplicados decréscimos de $1 \%$ até se obter o máximo carregamento admissível para o transformador.

Os valores de temperatura do enrolamento são comparados com os apresentados na tabela 4.1, mostrada a seguir, e dessa forma definimos os 4 patamares de sobrecarga para cada tipo de carregamento.

As possíveis restrições de carregamento da subestação, inseridas no módulo de manutenção, são reconhecidas automaticamente e os cálculos de carregamento máximo admissível são feitos com base nessas limitações. 
Tabela 4.1 - Patamares de Carregamento calculados pelo SGT

\begin{tabular}{|c|}
\hline Carregamento Máximo Admissível \\
\hline Condições Normais de Operação $\left(105^{\circ} \mathrm{C}\right)$ \\
\hline Acima das Condições Normais $\left(110^{\circ} \mathrm{C}\right)$ \\
\hline Emergência de Longa Duração $\left(115^{\circ} \mathrm{C}\right)$ \\
\hline Emergência de Curta Duração $\left(120^{\circ} \mathrm{C}\right)$ \\
\hline
\end{tabular}

Para cada patamar de carregamento há um tempo máximo no qual o transformador pode operar sem detrimento de sua vida útil e perda de confiabilidade.

Em alguns patamares de carga, como os de emergência, por exemplo, a operação nestas condições de temperatura pode causar aceleração do envelhecimento do papel isolante. [11].

Com base no cálculo de temperatura do ponto quente calculamos a perda de vida para cada condição de carregamento, conforme equacionamento e metodologia já exposta em 2.14 .

A figura 4.4 apresentada a seguir mostra o gráfico da curva de carga e os máximos patamares de carregamento calculados para o transformador a partir da curva de carga inserida no módulo de carregamento do SGT.

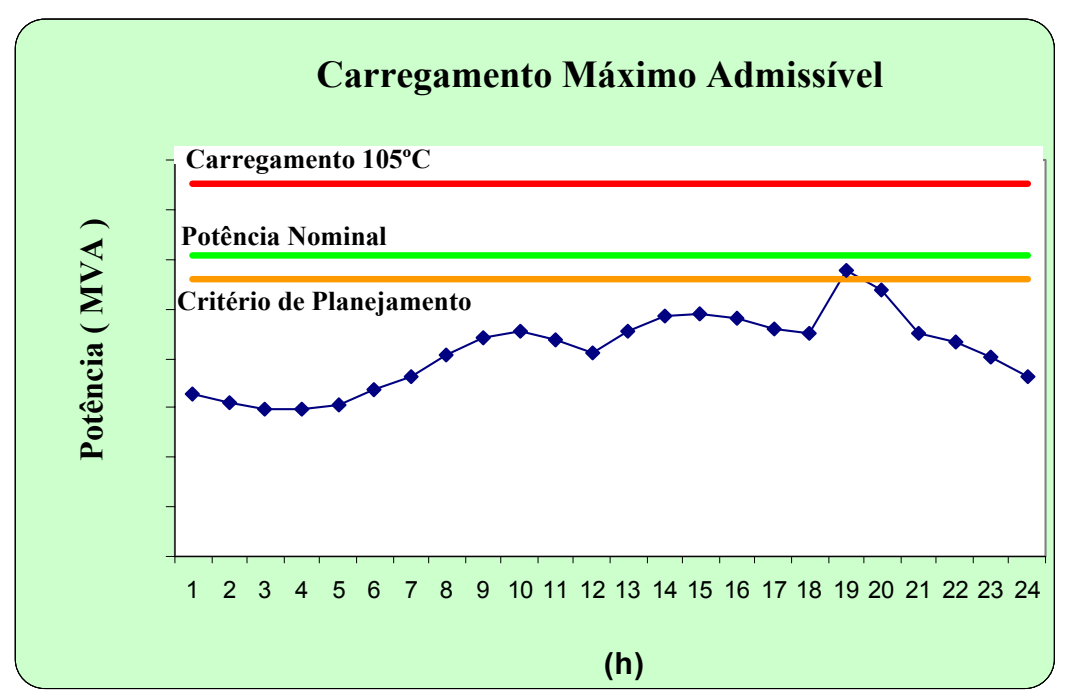

Figura 4.8 - Carregamento Máximo Admissível - Transformador 25 MVA . 
- Cálculo da Perda de Vida dos Transformadores no SGT.

Através do SGT, é possível determinar a perda de vida percentual da isolação sólida do transformador, imposta pela curva de carga segundo a Lei de Arhenius [11].

O cálculo da perda de vida permite ao usuário saber com antecedência se o ciclo de carga imposto causará aceleração da perda de vida útil da isolação do transformador.

Essa informação auxilia nas decisões sobre o equipamento e se realmente é vantajoso operá-lo acima das condições nominais por certos períodos de tempo.

O cálculo percentual da perda de vida é dada pela seguinte expressão:

$$
P V \%_{(j)}=\sum_{j=1}^{24} 100 \Delta t 10^{-\left(A+\frac{B}{\theta e_{(j)}+273}\right)}
$$

Onde:

$P V \%_{(j)}-$ Perda de vida percentual no instante $(\mathrm{j})$

$A$ e $B=$ são constantes da curva de expectativa de vida.

$A=-14,133$ para transformadores com elevação de temperatura de $55^{\circ} \mathrm{C}$.

$A=-13,391$ para transformadores com elevação de temperatura de $65^{\circ} \mathrm{C}$.

$B=6972,15$.

$\theta e_{(j)}=$ temperatura do ponto mais quente do enrolamento em ${ }^{\circ} \mathrm{C}$.

$\Delta t=$ Intervalo de tempo em horas.

O SGT pode ser utilizado para fins operativos como, por exemplo, estimativas de contingência, capacidade de socorro de cada transformador, análise das condições técnicas do equipamento, etc. 
No estudo de caso apresentado no capítulo 5 deste trabalho utilizaremos o SGT para análise de carregamento de um transformador cuja curva de carga ultrapassa o critério de planejamento da CPFL de 92,3\% da potência nominal

O SGT pode ser usado ainda como uma ferramenta de auxílio na tomada de decisão quanto ao melhor momento de investimentos, buscando a otimização dos ativos, o que poderá trazer ganhos tarifários em função da atual legislação do setor elétrico. 


\section{CAPÍTULO 5. ESTUdO DE CASO - AMPLIAÇÃO DA SE PENÁPOLIS}

O transformador de potência é o ativo mais caro de uma subestação, portanto, trata-se de um equipamento que necessita de acompanhamento durante a sua vida útil.

A Resolução ANEEL 44/1999 [2], estabelece que a vida útil de um transformador de potência é de 40 anos, ou seja, durante este período o poder concedente paga uma taxa de depreciação de $2,5 \%$ ao ano, com a finalidade de reposição deste ativo no final do período, mantendo a qualidade e confiabilidade no fornecimento.

Este assunto, bem como a legislação vigente, em relação ao processo de Revisão Tarifária, foram discutidos com maiores detalhes em 2.1 e serviram de base para o desenvolvimento do estudo de caso apresentado neste capítulo.

A proposta deste estudo de caso é mostrar como o gerenciamento de informações relevantes, dos transformadores e subestações, podem ser úteis na tomada de decisão sobre o momento adequado de se realizar obras de expansão do Sistema Elétrico.

No contexto atual do setor elétrico, a decisão sobre o momento correto de se realizar uma obra pode significar ganhos consideráveis, além de possibilitar a utilização plena da capacidade de seus ativos.

Algumas questões referentes ao processo de Revisão Tarifária das concessionárias distribuidoras de energia elétrica também foram analisadas.

O processo de Revisão Tarifária regulamentado pela ANEEL tem importância fundamental na forma de utilização dos ativos, sendo que, em vista da nova legislação do setor elétrico, o momento certo de investir pode trazer ganhos significativos, tanto na questão financeira quanto na utilização dos ativos.

Sendo a isolação parte fundamental para o funcionamento dos transformadores, nesta revisão foram levantadas as características da isolação dos transformadores e meios de gerenciamento para controle do envelhecimento destes equipamentos. 


\section{1 - Definição do melhor ano para o investimento.}

Para ilustrarmos os conceitos mostrados anteriormente foi feito um estudo específico de uma obra de ampliação de subestação.

De acordo com os critérios de Planejamento utilizados esta subestação deveria ter sua potencia ampliada no ano de 2006, porém, devido às questões tarifárias, o melhor momento para a realização de investimentos é no ano anterior ao da revisão, ou seja, no ano de 2008.

Na seqüência será demonstrada a metodologia utilizada para a tomada desta decisão e os ganhos obtidos com a postergação deste investimento.

\section{- Critérios de Planejamento das Subestações}

Os critérios de planejamento das concessionárias de energia elétrica são muito variados e atendem exigências particulares e estratégicas de cada uma. $\mathrm{O}$ critério utilizado neste estudo de caso é utilizado pela empresa CPFL e foi extraído da referência [21].

O critério utilizado estabelece que ações devem ser tomadas quando o transformador atinge $92,3 \%$ de sua potência nominal, ou seja, é o momento de realização de alguma.

A SE Penápolis conta com transformador de 25 MVA, 138-11,9 kV e com 3 saídas de alimentadores.

Os estudos indicaram que o critério de $92,3 \%$ da potência nominal do transformador, aproximadamente 23,1 MVA, seria atingido no ano de 2005 indicando a necessidade de obras de ampliação, ou construção de uma nova subestação no município no ano de 2006.

Independentemente da obra a ser realizada, por conta das questões tarifárias mostradas anteriormente, o melhor ano para se realizar investimentos é 2008, ano anterior à revisão tarifária da empresa a ser aplicada em 2009. 
Tendo em vista tal necessidade, o estudo propõe uma metodologia na qual o transformador é analisado de forma detalhada e calculado o seu carregamento máximo de acordo com as curvas características, obtidas pelo método estatístico apresentado no capítulo 3 .

\subsection{Metodologia de Análise}

A obra proposta seria a ampliação da SE Penápolis, com a instalação de um transformador de 40 MVA em substituição ao de 25 MVA existente e instalação de mais duas saídas de alimentadores em $11,9 \mathrm{kV}$.

Tendo em vista que 2006 não seria o melhor ano para se realizar investimentos, decidimos estudar o caso de forma mais detalhada e explorarmos a máxima capacidade do transformador segundo os critérios da norma NBR-5416/97, [9].

A metodologia foi dividida nas seguintes etapas:

1. Análise detalhada da subestação envolvida;

2. Análise das curvas características- Histórico e Projeções

3. Cálculo do Carregamento Máximo Admissível do Transformador em todas as curvas características de acordo com a NBR-5416/97, [11]

4. Análise dos resultados obtidos;

5. Análise financeira das soluções;

Cada uma das etapas citadas anteriormente tem suas particularidades que serão mostradas a seguir.

\subsubsection{Análise Detalhada da Subestação}

Nesta etapa foi feita uma análise detalhada na subestação visando identificar as condições operativas da instalação e se esta está preparada para operar acima de suas condições nominais, em caso de necessidade. 
Esta etapa é fundamental para identificarmos se há condições de prosseguirmos em nossa metodologia, pois em boa parte dos casos não é o transformador o fator limitante do carregamento da subestação.

Durante esta análise são levantadas as possíveis restrições que podem limitar o carregamento máximo da subestação e estudadas as possíveis soluções para eliminá-las.

Verificadas as condições desta subestação, nada de restritivo foi encontrado para liberação de potência da instalação já que os demais equipamentos como TP's, TC's, Disjuntores e Barramentos em geral estão dimensionados para atender uma possível necessidade de sobrecarga do transformador.

\subsubsection{Análise das Curvas Características}

Através do método estatístico apresentado no capítulo 3, obtemos a curva característica cuja demanda máxima atingiu o limite de 92,3\% indicando a necessidade de obras.

Uma vez obtida a curva característica do ano de 2005, que identificou a necessidade da obra, extraímos também o histórico de curvas para verificarmos o comportamento destas nos anos anteriores.

A função desta análise é verificar se as curvas dos anos anteriores se comportaram de maneira similar, variando apenas em sua amplitude segundo a taxa de crescimento adotada nos estudos.

A análise do comportamento do histórico de curvas nos dá a segurança para supormos que nos anos posteriores a 2005, estas se comportarão da mesma forma ao longo dos anos, aumentando segundo a taxa de crescimento dos estudos.

A figura 5.1 a seguir mostra o comportamento das curvas dos anos de 2002 a 2008, melhor período para a realização das obras. 


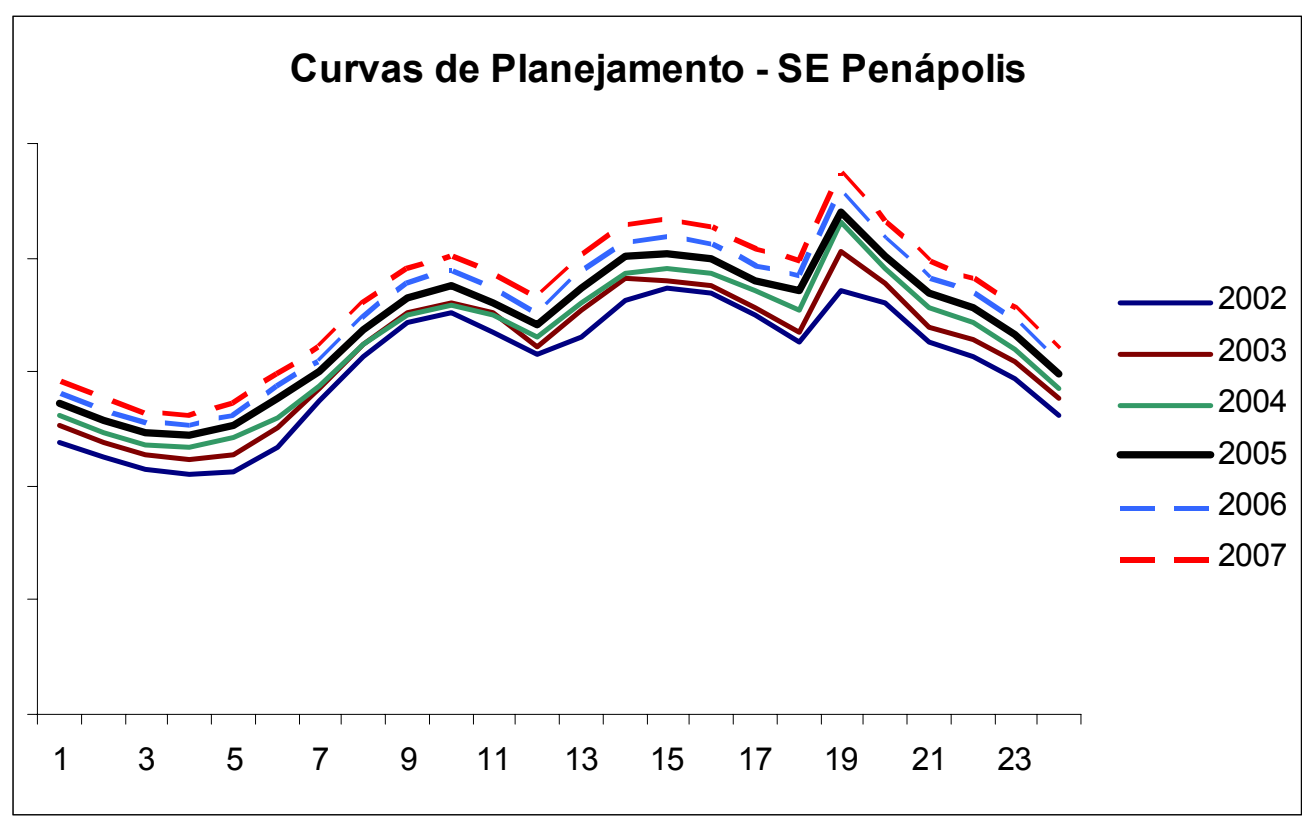

Figura 5.1 - Comportamento das Curvas Características (2002-2008)

Como pode ser visto na figura 5.1 a forma das curvas características não apresentaram mudanças significativas ao longo dos anos. Esta similaridade entre as curvas e a característica da região estudada nos dá a segurança de considerar que nos anos posteriores a 2006 a curva de comportará da mesma forma, variando somente em sua amplitude seguindo a taxa de crescimento da região.

\subsubsection{Cálculo do Carregamento Máximo Admissível}

A tabela 5.1 mostrada a seguir foi extraída da Orientação Técnica a respeito do carregamento dos transformadores das empresas do Grupo CPFL Energia [18] e serviram de referência para os cálculos do carregamento máximo admissível do transformador da SE Penápolis.

A base para o desenvolvimento da referência [18], de onde foi extraída a tabela 5.1, foi a NBR-5416/97 [11], que estabelece as diretrizes de carregamento dos transformadores de potência. 
Tabela 5.1 - Diretrizes de Carregamento de Transformadores - Grupo CPFL [18]

\begin{tabular}{|c|c|c|c|c|}
\hline \multicolumn{2}{|c|}{ Carregamento } & \multirow[t]{2}{*}{$\begin{array}{l}\text { Tipo de } \\
\text { Isolação }\end{array}$} & \multicolumn{2}{|c|}{$\begin{array}{l}\text { Temperaturas } \\
\text { Máximas }\end{array}$} \\
\hline Condição & Descrição & & Enrolamento & Óleo \\
\hline \multirow{2}{*}{ Normal } & \multirow{2}{*}{$\begin{array}{l}\text { Carregamento sem limite } \\
\text { de duração sem violar os } \\
\text { limites de temperatura } \\
\text { indicados. }\end{array}$} & $\begin{array}{c}\text { Kraft } \\
\text { Convencional }\end{array}$ & $105^{\circ} \mathrm{C}$ & $95^{\circ} \mathrm{C}$ \\
\hline & & Termoestabilizado & $120^{\circ} \mathrm{C}$ & $105^{\circ} \mathrm{C}$ \\
\hline \multirow[b]{2}{*}{$\begin{array}{l}\text { Acima das } \\
\text { condições } \\
\text { normais } \\
\text { planejadas }\end{array}$} & \multirow{2}{*}{$\begin{array}{l}\text { Carregamento r com } \\
\text { temperaturas } \\
\text { às condições noriores } \\
\text { com duração máxima de } \\
4 \text { horas e que não violem } \\
\text { os limites de temperatura } \\
\text { indicados }\end{array}$} & $\begin{array}{c}\text { Kraft } \\
\text { Convencional }\end{array}$ & $110^{\circ} \mathrm{C}$ & $100^{\circ} \mathrm{C}$ \\
\hline & & Termoestabilizado & $125^{\circ} \mathrm{C}$ & $110^{\circ} \mathrm{C}$ \\
\hline \multirow[b]{2}{*}{$\begin{array}{l}\text { Emergência } \\
\text { de Longa } \\
\text { Duração }\end{array}$} & $\begin{array}{lr}\text { Carregamento } & \text { com } \\
\text { temperaturas } & \text { superiores }\end{array}$ & $\begin{array}{c}\text { Kraft } \\
\text { Convencional }\end{array}$ & $115^{\circ} \mathrm{C}$ & $100^{\circ} \mathrm{C}$ \\
\hline & $\begin{array}{l}\text { às condições normais } \\
\text { com duração máxima de } \\
4 \text { horas e que não violem } \\
\text { os limites de temperatura } \\
\text { indicados }\end{array}$ & Termoestabilizado & $130^{\circ} \mathrm{C}$ & $110^{\circ} \mathrm{C}$ \\
\hline \multirow[b]{2}{*}{$\begin{array}{l}\text { Emergência } \\
\text { de Curta } \\
\text { Duração }\end{array}$} & $\begin{array}{l}\text { Carregamento admitido } \\
\text { pelo tempo necessário }\end{array}$ & $\begin{array}{c}\text { Kraft } \\
\text { Convencional }\end{array}$ & $120^{\circ} \mathrm{C}$ & $100^{\circ} \mathrm{C}$ \\
\hline & $\begin{array}{l}\text { para execução de } \\
\text { manobras e ou } \\
\text { transferência de cagas. O } \\
\text { tempo máximo é de } 30 \\
\text { minutos sem violação dos } \\
\text { limites de temperatura } \\
\text { indicados. }\end{array}$ & Termoestabilizado & $135^{\circ} \mathrm{C}$ & $110^{\circ} \mathrm{C}$ \\
\hline
\end{tabular}


Obs.: Papel Kraft Convencional - Transformadores com Classe de Isolação $55^{\circ} \mathrm{C}$ Papel Termoestabilizado - Transformadores com Classe de Isolação $65^{\circ} \mathrm{C}$

\section{Dados do Transformador da SE Penápolis}

Potência - 15/20/25 MVA

Tensão - 138/11,9 kV

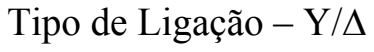

Tipo de Resfriamento - ONAN/ONAF/ONAF

Peso da Parte Ativa - $21 \mathrm{t}$

Peso do Tanque e Acessórios - 11,5 t

Volume de Óleo - 15.700 litros

$\Delta \mathrm{e}=46,6^{\circ} \mathrm{C}$ (Elevação da temperatura do enrolamento sobre a ambiente)

$\Delta \mathrm{o}=39,9{ }^{\circ} \mathrm{C}$ (Elevação da temperatura do óleo sobre a ambiente)

Temperatura Ambiente $=35^{\circ} \mathrm{C}$ (Valor utilizado para as simulações)

Com base nos dados mostrados anteriormente no capítulo 2 calculamos o máximo carregamento admissível para este transformador. Foi utilizada a temperatura de $35^{\circ} \mathrm{C}$ para as simulações cujos valores encontram-se na tabela 5.2 a seguir.

A temperatura adotada foi considerada constante durante o período, como sugere a norma NBR-5416/97 [11]. Apesar de sermos conservativos neste ponto, esta atitude nos dá uma margem de segurança, o que contribui para a integridade do equipamento e sistema de uma maneira geral.

Tabela 5.2 - Carregamento Máximo Admissível - Curva Característica Ano 2005

\begin{tabular}{|l|l|}
\hline \multicolumn{1}{|c|}{ CARREGAMENTO MÁXIMO ADMISSÍVEL } & $\%$ \\
\hline CONDIÇÕES NORMAIS DE OPERAÇÃO $\left(105^{\circ} \mathrm{C}\right)$ & 21 \\
\hline ACIMA DAS CONDIÇÕES NORMAIS $\left(110^{\circ} \mathrm{C}\right)$ & 26 \\
\hline EMERGÊNCIA DE LONGA DURAÇÃO $\left(115^{\circ} \mathrm{C}\right)$ & 26 \\
\hline EMERGÊNCIA DE CURTA DURAÇÃO $\left(120^{\circ} \mathrm{C}\right)$ & 26 \\
\hline
\end{tabular}


Considerando a curva característica do ano de 2005, o gráfico da figura a seguir mostra que a demanda máxima viola o critério de planejamento, sinalizando a necessidade de obras. Por outro lado, para este tipo de curva, segundo a norma NBR$5416 / 97$ [11] há a possibilidade de operar em 21\% acima da curva atual, de forma que no momento da demanda máxima a temperatura do enrolamento do transformador atingirá o valor de $105^{\circ} \mathrm{C}$.

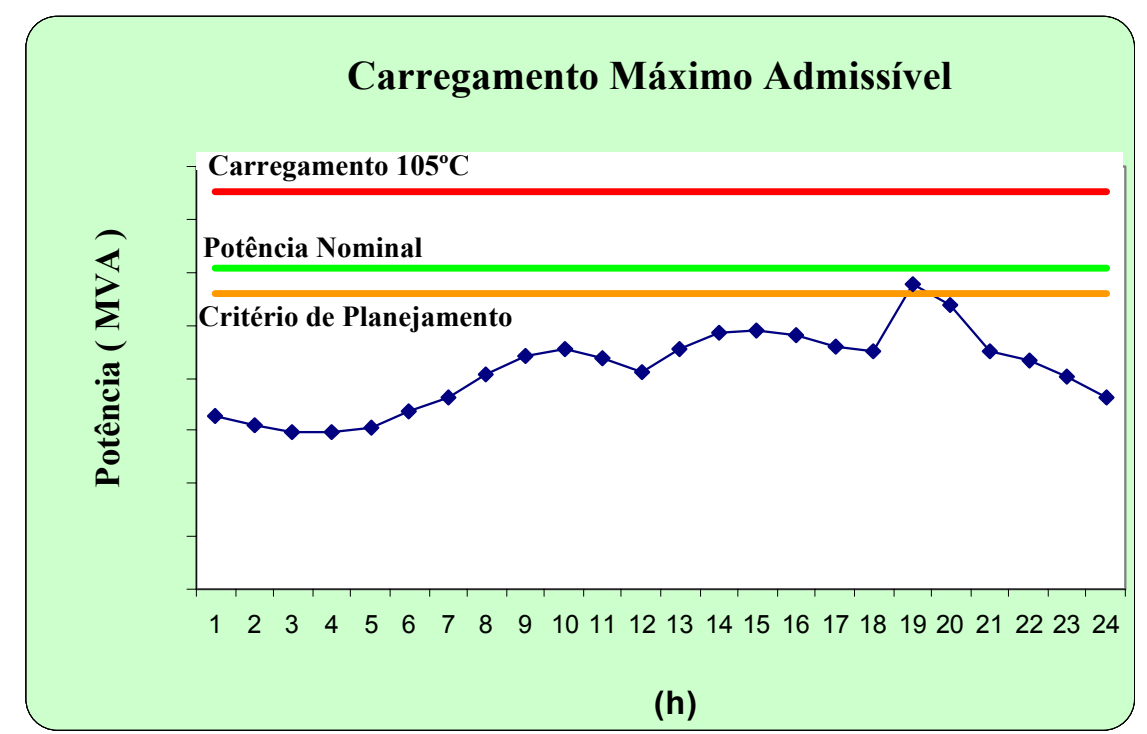

Figura 5.2 - Carregamento Máximo Admissível - Ano base 2005.

No gráfico de carregamento mostrado na figura 5.3 a linha laranja representa o critério de planejamento de $92,3 \%$, a verde a capacidade nominal do transformador e a vermelha o carregamento máximo admissível calculado para a temperatura de $35^{\circ} \mathrm{C}$.

Como pode ser visto na figura anterior, a demanda máxima viola o critério de planejamento durante um período bem pequeno, cerca de meia hora, razão pela qual essa obra poderia ser postergada. 
Considerando a taxa de crescimento utilizada nos estudos, foi feita a projeção da curva de 2005 para o ano de 2008 cujos valores foram utilizados na simulação de carregamento do mesmo transformador como pode ser visto na figura a seguir.

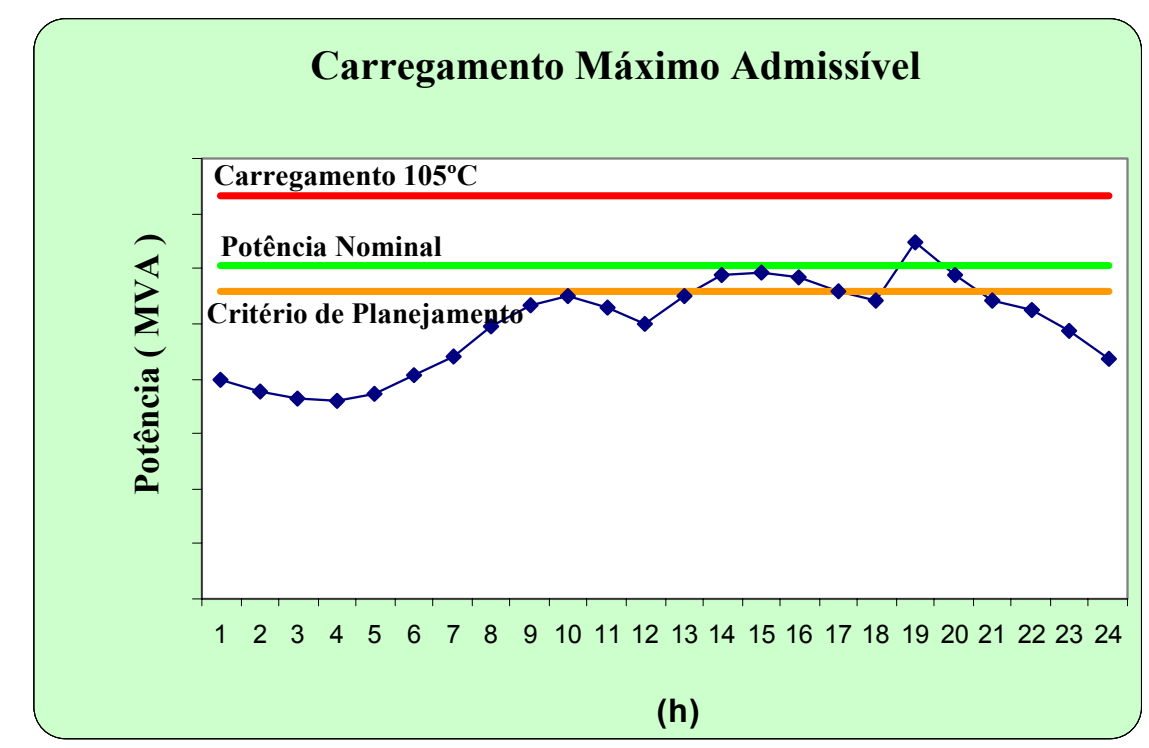

Figura 5.3 - Carregamento Máximo Admissível - Ano base 2008

Como pode ser visto na figura anterior, no ano de 2008, segundo as projeções, a demanda máxima ultrapassa a capacidade nominal do transformador por um pequeno período de tempo, porém, ainda está distante da capacidade máxima admissível, linha vermelha do gráfico.

Assim sendo, considerando que o transformador está dentro de suas condições operativas normais, esta obra pode ser postergada para o ano de 2008 trazendo ganhos significativos tanto financeiros quanto tarifários.

\section{- Cálculo da Perda de Vida do Transformador}

Com o propósito de se identificar a condição do transformador, simulamos a perda de vida do equipamento desde a sua energização na subestação. $O$ equipamento em questão foi energizado em 27/04/80 na referida subestação.

Para se efetuar os cálculos foram feitas algumas considerações. As curvas de carga entre os anos de 1980 a 1999, utilizadas para o cálculo de perda de vida do 
transformador foram obtidas por meio da demanda máxima de planejamento utilizada nos estudos e suas respectivas taxas anuais de crescimento.

A partir da demanda máxima de planejamento obtida nos estudos históricos históricos realizados pela CPFL, foi feita uma distribuição proporcional considerando a forma da curva de carga obtida pelo método estatístico apresentado no capítulo 3.

A forma da curva foi considerada igual em todos os anos variando somente a amplitude de acordo com a taxa de crescimento apontada nos estudos de planejamento para a região.

Para efeito de cálculo foi considerado que a curva de carga se repetiu durante todo o ano.

Com base nestas curvas, calculamos a temperatura do enrolamento do transformador e posteriormente sua perda de vida percentual pela Lei de Arhenius. [11]

A figura 5.5 a seguir mostra as curvas de carga utilizadas para o cálculo de perda de vida útil do transformador. As curvas tracejadas são projeções considerando a taxa de crescimento vegetativo utilizada nos estudos de planejamento.

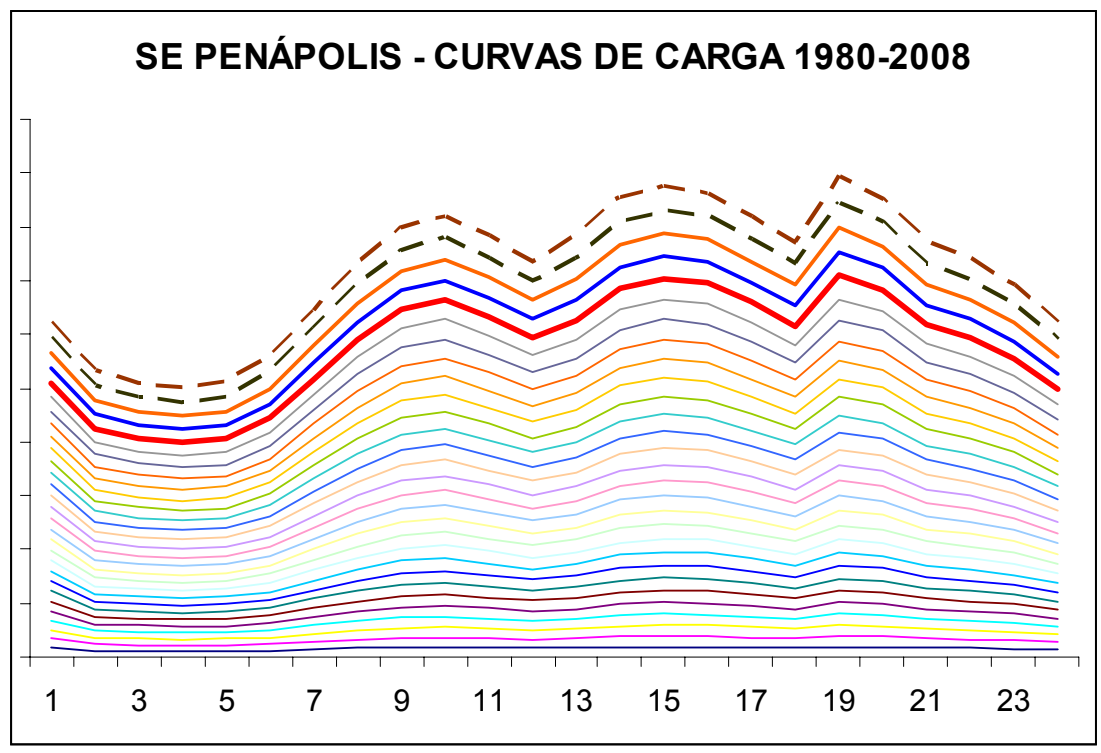

Figura 5.4 - Curvas de Carga da SE Penápolis - 1980 a 2008 
Tendo-se em vista que a demanda inicial da SE Penápolis foi da ordem de 12 MVA, pouco menos que $50 \%$ da capacidade do transformador, a perda de vida a que foi submetido o transformador foi bem pequena.

A tabela 5.3 a seguir mostra um resumo dos valores de perda de vida, calculados em valores percentuais no período entre 1980 a 2005, conforme metodologia e equacionamento apresentado em 2.14.2, onde foi abordada em detalhes esta questão.

Tabela 5.3 - Valores de Perda de Vida do Transformador - SE Penápolis

\begin{tabular}{|c|c|c|c|c|}
\hline \multirow[t]{2}{*}{ Ano } & \multicolumn{2}{|c|}{ Expectativa de Vida } & \multirow{2}{*}{$\begin{array}{r}\text { PV }(\%) \\
\text { Anual }\end{array}$} & \multirow{2}{*}{$\begin{array}{c}\text { PV }(\%) \\
\text { Ciclo de Carga }\end{array}$} \\
\hline & (Anos) & Horas & & \\
\hline 1980 & 4319 & 37837531,2 & 0,02315162 & $6,34291 \mathrm{E}-05$ \\
\hline 1981 & 4068 & 35638434 & 0,0245802 & $6,7343 \mathrm{E}-05$ \\
\hline 1982 & 3828 & 33530116,3 & 0,02612577 & $7,15774 \mathrm{E}-05$ \\
\hline 1983 & 3581 & 31365669,1 & 0,02792862 & $7,65168 \mathrm{E}-05$ \\
\hline 1984 & 3345 & 29298826,6 & 0,02989881 & $8,19145 \mathrm{E}-05$ \\
\hline 1985 & 3105 & 27200280,7 & 0,03220555 & $8,82344 \mathrm{E}-05$ \\
\hline 1986 & 2877 & 25205230,3 & 0,03475469 & $9,52183 \mathrm{E}-05$ \\
\hline 1987 & 2649 & 23203308,8 & 0,03775324 & 0,000103434 \\
\hline 1988 & 2433 & 21310595,1 & 0,04110631 & 0,00011262 \\
\hline 1989 & 2219 & 19435141,3 & 0,04507299 & 0,000123488 \\
\hline 1990 & 2018 & 17673862,5 & 0,04956472 & 0,000135794 \\
\hline 1991 & 3897 & 34140456,6 & 0,02565871 & $7,02978 \mathrm{E}-05$ \\
\hline 1992 & 1638 & 14347963,1 & 0,06105396 & 0,000167271 \\
\hline 1993 & 1461 & 12802369,9 & 0,06842483 & 0,000187465 \\
\hline 1994 & 1299 & 11375985,5 & 0,07700432 & 0,000210971 \\
\hline 1995 & 1144 & 10022822,9 & 0,08740053 & 0,000239453 \\
\hline 1996 & 1003 & 8787640,3 & 0,09968546 & 0,000273111 \\
\hline 1997 & 872 & 7635278,83 & 0,11473058 & 0,00031433 \\
\hline 1998 & 753 & 6596547,78 & 0,13279673 & 0,000363827 \\
\hline 1999 & 644 & 5644690,11 & 0,1551901 & 0,000425178 \\
\hline 2000 & 548 & 4798876,17 & 0,18254274 & 0,000500117 \\
\hline 2001 & 461 & 4038559,39 & 0,21690903 & 0,000594271 \\
\hline 2002 & 385 & 3368709,71 & 0,26004022 & 0,000712439 \\
\hline 2003 & 297 & 2602562,72 & 0,33659131 & 0,000922168 \\
\hline 2004 & 243 & 2128276,06 & 0,41160074 & 0,001127673 \\
\hline 2005 & 193 & 1687578,19 & 0,51908706 & 0,001422156 \\
\hline 2006 & 92 & 803669,893 & 1,08999977 & 0,002986301 \\
\hline 2007 & 71 & 624345,031 & 1,40307035 & 0,003844028 \\
\hline 2008 & 46 & 406572,867 & 2,15459533 & 0,005903001 \\
\hline
\end{tabular}


Como pode ser visto na tabela 5.3, os valores encontrados no cálculo de perda de vida foram pequenos, resultado já esperado devido aos baixos patamares de carga alimentados pelo transformador.

Se considerarmos que o transformador sempre operasse na curva do ano de 2005, ainda assim o tempo de vida útil do papel isolante seria de aproximadamente 200 anos.

A tabela 2.2 apresentada em 2.4.2 apresenta valores de referência de teor de oxigênio, índice de neutralização e umidade do papel isolante para aderência total da perda de vida estimada com a real.

Por outro lado, quando o óleo e ou papel isolante ultrapassam os valores da tabela 2.2, a expectativa de vida calculada pela Lei de Arhenius servirá apenas de referência, pois o grau de envelhecimento obtido não corresponderá à idade cronológica do transformador [11].

Para avaliarmos o quanto a perda de vida calculada tem relação com a realidade, apresentamos gráfico comparando os dados extraídos do SGT e os valores recomendados pela NBR-5416/97 [11], para a aplicação na íntegra da Lei de Arhenius.

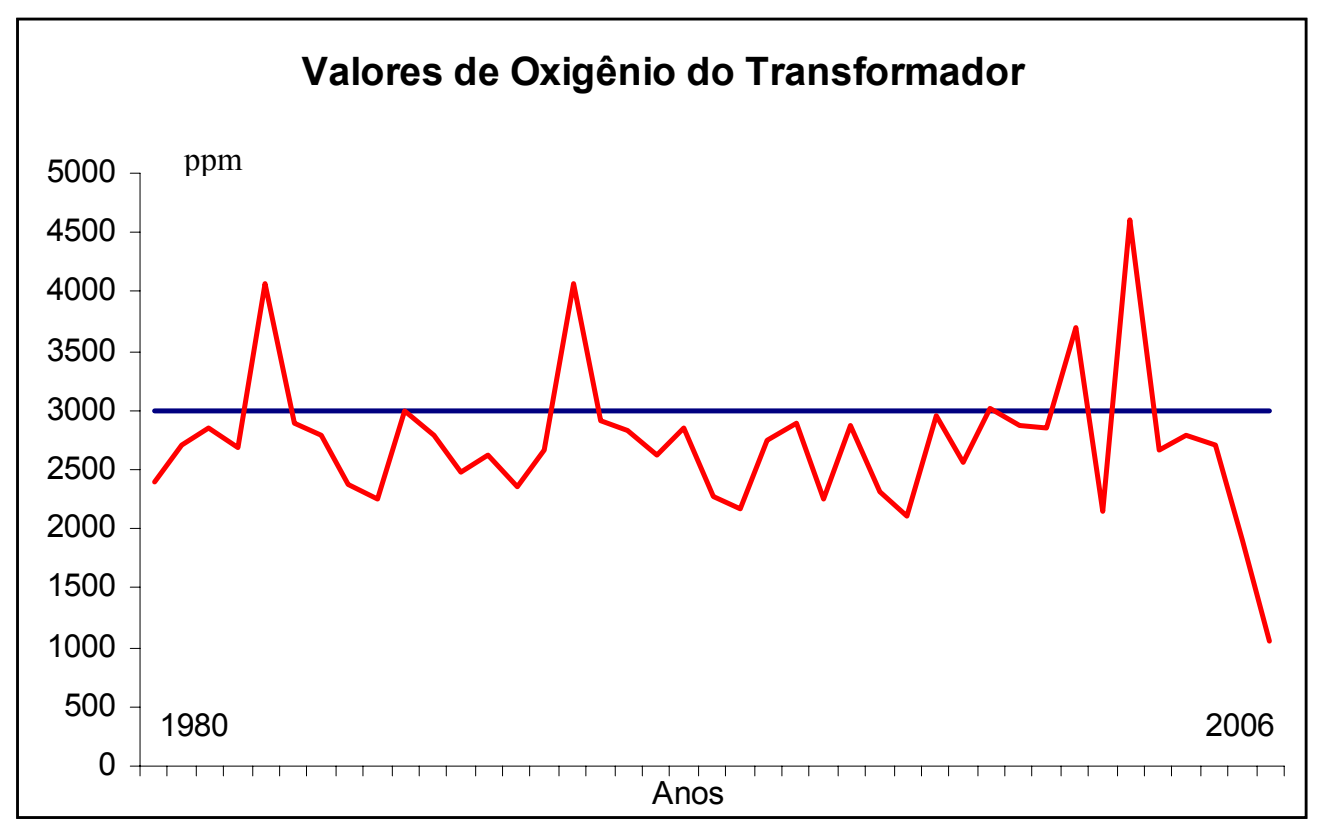

Figura 5.5 - Gráfico de evolução dos teores de Oxigênio no óleo isolante 
A linha azul na figura 5.5 representa o valor de $3000 \mathrm{ppm}$ recomendado pela referência [11] para a aderência total da Lei de Arhenius quanto ao envelhecimento do papel isolante.

Como podemos notar na figura mostrada anteriormente, apenas em 3 períodos ao longo dos anos de utilização do transformador o teor de Oxigênio no óleo isolante foi superior a $3000 \mathrm{ppm}$.

Este valor ultrapassou o limite estabelecido na ocasião de manutenções onde foi necessária a abertura do transformador e por conseqüência o óleo isolante teve contato direto com o oxigênio.

Tais informações foram obtidas no módulo de manutenção do SGT onde consta todo o histórico de intervenções do equipamento ao longo de sua vida operativa.

Dando continuidade a análise, extraímos do SGT o histórico de valores de índice de neutralização, ou acidez, do óleo isolante e comparamos com o valor recomendado na tabela 2.11, recomenda-se que este valor esteja abaixo de 0,1 $\mathrm{mg} / \mathrm{KOH}$. A figura a seguir mostra a variação destes valores desde a energização do transformador.

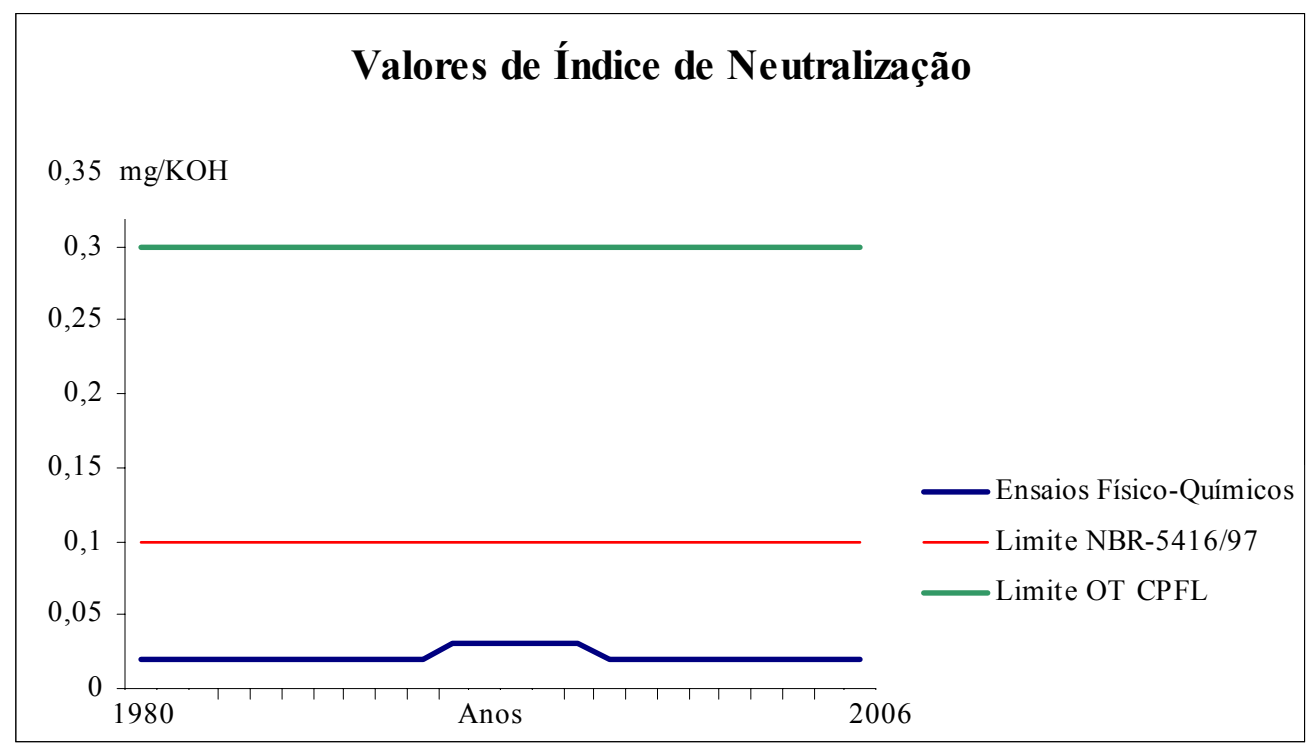

Figura 5.6 - Gráfico de evolução do Índice de Neutralização no óleo isolante 


\subsubsection{Análise dos Resultados Obtidos}

Considerando os valores obtidos nas simulações da etapa anterior, vemos que a obra de ampliação da SE Penápolis pode ser postergada sem maiores riscos, devido ao comportamento da sua curva de carga.

Analisando sob a ótica da perda de vida percentual do transformador, podemos considerar que os valores estão abaixo dos esperados para uma vida útil de 40 anos.

Ainda que o equipamento operasse todos os dias nesta curva de carga a uma temperatura de $35^{\circ} \mathrm{C}$ constante, sua vida útil seria de aproximadamente 46 anos.

Considerando que as condições do óleo isolante estão adequadas como pôde ser visto nos gráficos de valores históricos de Oxigênio e Índice de Neutralização, é razoável considerarmos que a Lei de Arhenius tem uma boa aderência nesse caso minimizando os riscos da postergação desta obra.

Esta postergação certamente trará benefícios financeiros e tarifários já que se esta obra fosse realizada no ano de 2006, como indicava o critério de planejamento, o investimento realizado não seria totalmente remunerado, uma vez que teríamos dois anos de depreciação dos equipamentos e redução da base de ativos da empresa, parte fundamental no processo de revisão tarifária.

Como os equipamentos da SE Penápolis encontram-se em condições normais de operação, a postergação desta obra para o ano de 2008 é justificável, tanto no ponto de vista técnico quanto econômico.

Os ganhos econômicos desta postergação poderão ser observados com maiores detalhes nos cálculos e simulações que serão efetuadas na etapa seguinte desta metodologia.

\subsection{5 - Análise Financeira das Soluções}

Considerando os conceitos utilizados para os cálculos da revisão tarifária, o melhor ano para investimentos é o ano de 2008, ano anterior à revisão. Além disso, a postergação desta obra propicia a otimização dos ativos principalmente os transformadores. 
Para a realização desta obra de ampliação da SE Penápolis seria necessário um investimento de R \$ 4,1 Milhões aproximadamente, contemplando a substituição do transformador de 25 por outro de 40 MVA, instalação de 3 saídas de alimentadores em $11,9 \mathrm{kV}$ e adequação do setor $138 \mathrm{kV}$ da subestação.

Utilizando o equacionamento apresentado a seguir, calculamos o valor presente do investimento nas duas datas de realização das obras, ou seja, em 2006 e 2008 [61].

$$
V p=\frac{V n}{(1+j)^{n}}
$$

$V p$ - Valor Presente do Investimento;

$V n$ - Valor Atual do Investimento;

$j$ - Taxa Anual de Juros;

$n$ - Número de anos

Tabela 5.4 - Valores Comparativos de Investimentos (Valor Presente)

\begin{tabular}{|l|c|c|}
\hline Investimento & $\mathbf{2 0 0 6}$ & $\mathbf{2 0 0 8}$ \\
\hline Opção 1 & $\mathrm{R} \$ 4.100 .000,00$ & $\mathrm{R} \$ 3.895 .000,00$ \\
\hline Opção 2 & $\mathrm{R} \$ 3.100 .000,00$ & $\mathrm{R} \$ 3.500 .000,00$ \\
\hline
\end{tabular}

Obs.: Taxa de Juros $-15 \%$ ao ano.

Tabela 5.5 - Ganhos obtidos com a postergação da obra

\begin{tabular}{|l|l|}
\hline \multicolumn{2}{|c|}{ Ganhos Obtidos } \\
\hline Postergação da Obra & $\mathrm{R} \$ 1.000 .000,00$ \\
\hline Diferença Base Ativa & $\mathrm{R} \$ 205.000,00$ \\
\hline Ganho Total & R\$ 1.205.000,00 \\
\hline
\end{tabular}


Inicialmente temos um ganho de aproximadamente $\mathrm{R} \$ 1,2$ milhões, só com a postergação desta obra em 2 anos. Aliados a este ganho inicial, existe ainda um ganho de aproximadamente $2 \%$ na cota de reintegração e um aumento da base de ativos para cálculo da revisão tarifária. 


\section{CAPÍTULO 6 - CONCLUSÕES}

Neste trabalho foi desenvolvida uma ferramenta de gestão, que organiza as informações coletadas muitas vezes armazenadas de forma dispersa. O tratamento dos dados disponíveis proporciona uma análise detalhada do estado equipamento.

Através do SGT é possível analisar o transformador sob diferentes enfoques como envelhecimento, diagnóstico do óleo isolante, carregamento máximo admissível, etc.

Além das questões técnicas dos equipamentos, no SGT foi desenvolvido um módulo estatístico que faz o agrupamento das curvas de carga dos transformadores, com a finalidade de obtenção de curvas características. Estas curvas foram utilizadas nos estudos e análises de carregamento máximo admissível.

Assim sendo, o SGT torna-se uma ferramenta de consulta importante para diversos setores que utilizam o transformador como, Engenharia de Manutenção, Operação, Planejamento, etc. Esta única fonte de consultas permite a Gestão Integrada do equipamento.

O gerenciamento de transformadores de potência é um assunto que vem sendo estudado há muito tempo em âmbito nacional e internacional, porém, no momento atual do Setor Elétrico Brasileiro, essa atividade passou a ser questão de sobrevivência competitiva, sobretudo para as distribuidoras.

Essas informações, tratadas no SGT colaboram na tomada de importantes decisões, minimizando os riscos envolvidos, por exemplo, na necessidade de operação do transformador acima das capacidades nominais em determinados intervalos de tempo.

A utilização do transformador acima das condições nominais implica em operá-lo em condições, cujo aumento de temperatura tem influência direta no processo de degradação da celulose, componente da isolação sólida da grande maioria dos transformadores.

Sendo a temperatura de operação tão importante ao equipamento, é razoável dizer que quanto maior a exatidão das medições de temperatura do óleo e enrolamento dos transformadores, maior será confiabilidade e segurança para carregamentos acima das condições nominais, quando necessário [29]. 
Assim sendo, quando promovemos a modernização dos sistemas de medição de temperatura de um transformador, ganhamos em confiabilidade, já que a operação do equipamento poderá ser feita de maneira mais segura, minimizando os riscos.

As temperaturas do óleo e enrolamento, aferidas com maior precisão, permitem efetuar os cálculos de perda de vida e carregamento máximo admissível de forma mais precisa.

Outro ponto muito importante para a operação dos transformadores é a condição do óleo isolante. Através do SGT é possível fazer o acompanhamento detalhado e criterioso de cada equipamento em particular.

$\mathrm{O}$ envelhecimento do transformador está diretamente ligado à oxidação do óleo isolante nele contido. Sendo esse processo inevitável, através do SGT é possível minimizar os seus efeitos e executar as devidas ações de correção na hora certa, retardando o processo de envelhecimento do transformador.

Face ao exposto, vale ressaltar a importância da manutenção dos ativos da subestação, sobretudo dos transformadores de potência, pois dependendo do caso um investimento em manutenção realizado ao longo de sua vida operativa, além de manter o nível de confiabilidade adequado, pode significar a postergação de investimentos e ganhos tarifários para a empresa.

A importância da manutenção dos ativos fica evidenciada no estudo de caso apresentado neste trabalho. O transformador da SE Penápolis foi estudado e avaliado no SGT através de seus dados históricos de manutenção e óleo isolante. Essa análise permitiu a postergação da obra por 2 anos, possibilitando ganhos devido às questões tarifárias.

O constante investimento em manutenção, ao longo dos 25 anos de operação do transformador, ajudou na tomada de decisão, já que as devidas intervenções no óleo isolante foram feitas nos períodos corretos, retardando o processo de oxidação possibilitando um ganho de aproximadamente R\$ 1,2 milhões por conta da postergação da obra de ampliação da subestação.

Além dos ganhos anteriormente citados, existem benefícios quanto à revisão tarifária, ainda em processo de avaliação pela empresa. 
Em virtude do novo contexto do Setor Elétrico, este trabalho nos auxilia em uma reflexão sobre a otimização da utilização de ativos e critérios de planejamento nas empresas de distribuição.

Com a competitividade imposta pelo novo modelo, a realização de investimentos em anos estratégicos passou a ser uma questão de sobrevivência no setor. Essa competitividade acirrada leva algumas vezes à redução de custos na manutenção dos ativos. Essa política não é mais indicada já que além de colocar em risco a integridade do equipamento e do sistema elétrico como um todo, compromete a postergação de obras.

Além disso, cabe à empresa pública ou privada manter o patrimônio público, promovendo as ações necessárias no sistema, tendo em vista sempre a manutenção dos níveis de qualidade e fornecimento, aliados à uma tarifa justa ao cliente final. 


\section{BIBLIOGRAFIA}

[1] CIGRE Working Group Life Management of Transformers, Final Report "Life Management Techniques for Power Transformers" - 2005;

[2] Resolução ANEEL no 44/1999;

[3] Resolução ANEEL no 493/2002;

[4] Nota Técnica ANEEL nº 178/2003;

[5] Contrato de Conexão das Distribuidoras de Energia - ANEEL - 1997;

[6] Análise e Otimização das Perdas Técnicas em Sistemas de Distribuição - CODI;

[7] NBR-5356/93 - Transformador de Potência - Especificação;

[8] NBR-5356/93 - Transformador de Potência - Métodos de Ensaio;

[9] NBR-5416/97 - Aplicação de cargas em Transformadores de Potência Procedimento;

[10] MILASCH, M. Manutenção em Transformadores em Líquido Isolante Eletrobrás/EFEI. Edgard Blücher Ltda, 1984.

[11] NBR 7274/82. Interpretação e Análise dos Gases de Transformadores em serviço;

[12] MESSIAS, J. R - Guia Prático de Ensaios Físico-Químicos na Manutenção de Transformadores em Óleo - Cone Editora, 1993;

[13] Orientação Técnica 4096 - Sistema de Análise Diagnóstico e Gerenciamento de Manutenção Preditiva de Transformadores e Reguladores de Tensão de Subestações. Grupo CPFL, Junho/2003.

[14] GCOI, Grupo Coordenador para Operação Interligada. Revisão SCM 047 Recomendação para Utilização da Análise Cromatográfica em Óleo Mineral Isolante na Recepção e na Manutenção de Equipamentos - 1995; 
[15] IEEE Std C55.104-1991. Guide for the Interpretation of Gases Generated in Oil-Imersed Transformes. June 1991;

[16] JOSEPH, B. D. Dissolved Gas Analysis of Mineral Oil Insulating Fluids. Northern Technology \& Testing, 2002.

[17] MENDES, J.C - Redução de Falhas em Grandes Transformadores de Potência. Tese de Doutorado - Escola Politécnica da Universidade de São Paulo - USP, 1995;

[18] Orientação Técnica 4148. Diretrizes para Carregamento de Unidades Transformadoras. Grupo CPFL, Junho/2003;

[19] IEEE Std C57.91-1995. Guide for Loading Mineral Oil Ommersed Transformers. June 1994.

[20] BRITTES, J. L. P. Sistema de Automação para Gestão de Carregamento de Transformadores Baseado na Confiabilidade. Tese (Doutorado) - Escola Politécnica da Universidade de São Paulo - USP , 2002.

[21] Orientação Técnica 2331. Planejamento de Subestações. Grupo CPFL, Dezembro/2002;

[22] THOMAS A.P - Thermally Upgraded Insulation in Transformers - Workspot 2006 - Anais do Congresso - Recife - PE - Brasil.

[23] Alves, M.E.G. - Monitoração de buchas condensivas com papel impregnado com óleo - Dissertação de Mestrado EPUSP 2004.

[24] Bartley P.E - Analysis of Transformer Failures - International Association of Engineering Insures $36^{\mathrm{TH}}$ Conference - Stockholm 2003 - Final Report.

[25] ELECTRA. An International Survey on Failures in Large Power Transformer in Service. Paris: CIGRE, Ref. no. 88, 1983 - pg 21-48.

[26] Catálogos Diversos de Fabricantes de Transformadores - ABB e Siemens; 
[27] IEC 60354 October/1991. Loading Guide for Oil-Immersed Power Transformers.

[28] IEEE/ANSI C57.12.00/1993. General Requirement for Liquid-Immersed Distribution, Power and Regulating Transformers.

[29] Vasconcellos, V - Modernização dos sistemas de medição de temperatura e regulação de tensão de um transformador de 60 MVA. XVII SNPTEE - Uberlândia MG - Outubro de 2003.

[30] Projeto NBR IEC 60599. Guia de Interpretação da Análise dos Gases Livres e Dissolvidos. Junho/2001;

[31] Transformer Oil Handbook - NYNAS - June 2004;

[32] ABNT MB 351 - Determinação da cor em produtos de petróleo (método do colorímetro ASTM). (ABNT/IBP);

[33] ABNT MB 101 - Determinação do índice de neutralização de produtos de petróleo (Método do indicador);

[34] NBR-12133 - Determinação das perdas dielétricas em corrente alternada e constante dielétrica de líquidos isolantes elétricos - Junho/1991;

[35] NBR-6234 - Determinação de tensão interfacial de óleo-água - 1965;

[36] NBR-10710 - Determinação de água em líquidos isolantes (Método KARLFISCHER) - Maio/2006;

[37] NBR-6869 - Líquidos isolantes elétricos - Determinação da rigidez dielétrica (eletrodos de disco) - Dezembro/1989;

[38] NBR-7148 - Determinação da densidade de petróleo e derivados (método de densímetro) - Julho/2001; 
[39] CHEIN L, SILVEIRA J.G - How Long Should a Transformer Live A New Technical-Economical Approach - Workspot 2006 - Anais do Congresso - Recife PE - Brasil.

[40] Alain F.S. Levy, Neves A, Chagas F.A, Chaves J.A.M - Diagnóstico Integrado de Transformadores de Potência - Aplicação - XV SNPTEE - outubro 1999 - Foz do Iguaçu - PR - Brasil.

[41] Cheim L, Varella V, Dupont C, Páal R - Sistema Inteligente de Diagnóstico de Transformadores de Potência - XV SNPTEE - outubro 1999 - Foz do Iguaçu - PR Brasil.

[42] Dupont C.J, Cheim L.A.V, Fernandez J.B, Filho F.A DUPONT, C.J., CHEIM, L.A. Novo Modelo para Avaliação da Vida Remanescente de Transformadores; XIV SNPTEE, Outubro 1997 - Belém - Brasil.

[43] Diogo A.C.T - Avaliação da Vida Útil de Transformadores de Potência através da Cromatografia Líquida de Alto Desempenho XIV SNPTEE, Outubro 1997 Belém - Brasil.

[44] Dupont C.J, Cheim L.A.V, Fernandez J.B, Filho F.A - Programa GP2FAL - A substituição do GP por uma técnica não invasiva para diagnóstico de transformadores - XV SNPTEE - outubro 1999 - Foz do Iguaçu - PR - Brasil.

[45] Mak J, Vasconcellos V, Maciel L.R, Franchini L.R - Desenvolvimento de Transformador de Distribuição de Maior Vida Útil e Menor Agressividade Ambiental - Workspot 2006 - Anais do Congresso - Recife - PE - Brasil.

[46] Mc Shane C.P, Luksich J, Rapp K.J - Retrofilling Aging Transformers with Natural Ester Based Dielectric Coolant for Safety and Life Extension - IEEEIAS/PCA - Cement Industry Conference - May 2003 - Dallas TX. 
[47] CIGRÉ - Grupo de Trabalho D1- Relatório Técnico D1-01-002/05 - Enxofre Corrosivo em Óleo Mineral Isolante.

[48] Kanashiro A.G, Gervásio L.C. Neto, Malagodi C.V.S - Sistema de Monitoramento de Equipamentos de Subestações Desenvolvimento e Implantação XV SNPTEE - outubro 1999 - Foz do Iguaçu - PR - Brasil.

[49] Dupont C.J, Chaves J.A.M - Metodologia para Avaliação das Condições Admissíveis de Sobrecarregamento e da Perda de Vida útil de Transformadores - XV SNPTEE - outubro 1999 - Foz do Iguaçu - PR - Brasil.

[50] Rodrigues, C. M. Gerenciamento de Potência Transformadora em Subestações de Distribuição de 88 e 138kV. 2005. 74 p. (Mestrado) - ESCOLA POLITECNICA, Universidade de São Paulo, São Paulo, 2005

[51] Brandão Jr, A. F. - Políticas de Instalação e Operação de Transformadores. 1978. 1v. (Mestrado) - ESCOLA POLITECNICA, Universidade de São Paulo, São Paulo, 1978

[52] Oliveira C.C.B, Kagan N, Robba E.J - Introdução aos Sistemas de Distribuição de Energia Elétrica - Editora Edgard Blucher - 2005.

[53] Vasconcellos V, Zanetta Jr L.C - Determinação do Carregamento Máximo Admissível de Transformadores de Potência Através de Curvas de Carga Características - XVII SENDI - Agosto 2006 - Belo Horizonte MG - Brasil.

[54] BUSSAB, Wilton O, MORETTIN, Pedro A. Estatística Básica. $3^{\text {a }}$ ed. São Paulo, Atual 1986.

[55] KLEIBAUM, David G., KUPPER, Lawrence L. Applied Regression Analysis and Other Multivariable Methods. North Scituate, Massachusetts: Duxbury Press, 1978. 
[56] Mc NUTT W.J, Insultation Thermal Life Considerations for Transformers Loading Guides - Transactions on Power Delivery - 1992;

[57] BLAKE J.H - Oil Immersed Power Transformer Overload Calculations by Computer - IEEE Transactions on Power - 1969;

[58] BARTLEY W.H - Life Cycle Management of Utility Transformer Assets Breakthrough Asset Management for the Restructured Power Industry - Salt Lake City - Utah - Outubro/2002.

[59] Óleo Mineral Isolante - Relatório Técnico CEDOC Petrobrás - 1982.

[60] http://www.r-project.org

[61] Dutra J.V.S - Matemática Financeira - Editora Atlas - 1998. 


\section{APÊNDICE A - CARACTERÍSTICAS PRINCIPAIS DOS TRANSFORMADORES DE POTÊNCIA}

\section{- Definição das características dos transformadores [26]}

Antes do processo de aquisição de um transformador de potência destinado a sistemas elétricos, são realizados estudos complexos envolvendo o planejamento da evolução de carga nas regiões abrangidas, adequabilidade às condições de operação e manutenção, conformidade aos padrões e normas técnicas, intercambiabilidade com unidades existentes, quesitos de segurança e reserva técnica estratégica.

Destes estudos resulta uma série de características do transformador que visam satisfazer as necessidades de um sistema elétrico, tais como potência, tensão, freqüência, tipo de ligação, deslocamento angular, relações de transformação, suportabilidade elétrica da isolação e mecânica a curtos-circuitos, tipo e localização de comutadores, características térmicas, tipos de sistema de resfriamento, localização de acessórios, eventuais limitações dimensionais, atendendo as prescrições das normalizações técnicas de projeto e construção, de segurança e ambientais pertinentes.

As especificações traduzem estas necessidades em forma de documento técnico com o detalhamento adequado do transformador a ser adquirido, introduzindo ainda prescrições relacionadas a aprovação de documentação técnica (desenhos, manual de instruções, cronograma, plano de controle de qualidade, etc.), as garantias técnicas, bem com comprovações da conformidade do projeto através de inspeções e ensaios em matéria prima e/ou em fases importantes do processo de fabricação (enrolamentos, núcleo, parte ativa, etc.), bem como durante o recebimento do transformador completamente montado e acabado (ensaios de rotina, de tipo e especiais).

\section{- Normalização Técnica}

A normalização é elaborada segundo procedimentos e conceitos emanados do Sistema Nacional de Metrologia, Normalização e Qualidade Industrial, sendo 
resultante de consenso nos diferentes fóruns que envolvem o Governo, Setor Produtivo, Comércio e Consumidores.

As normas visam obter a defesa dos interesses nacionais; a racionalização na fabricação e produção e na troca de bens e serviços; proteção dos interesses dos consumidores; segurança de bens e pessoas; preservação do meio ambiente; uniformidade dos meios de expressão e comunicação. [7], [8], [9] e [28].

\section{- Definições e Conceitos}

Para melhor compreensão dos aspectos conceituais relacionados a transformadores de potência, torna-se fundamental o conhecimento de termos e definições adotadas, dentre outras, transformador; auto transformador; banco de transformadores; comutador de derivações; terminais (alta, baixa, neutro, aterramento, etc.); derivação; enrolamentos (alta, baixa, média, primário, secundário, terciário, etc.); tipos de ligação (delta, estrela, série, paralelo), os quais podem ser encontrados nos primeiros capítulos na Normalização Brasileira [7] [8] [9].

A aplicação de transformadores é muito ampla dentro de um sistema elétrico de potência, podendo ser utilizado em subestações de usinas geradoras, subestações de sistemas de transmissão, subestações de sistemas de distribuição, redes de distribuição e sistemas fabris.

$\mathrm{Na}$ geração, a tensão das máquinas geralmente é da ordem de $13,8 \mathrm{kV}$, que deve ser elevada (transformadores elevadores) para viabilizar a transmissão de energia para utilizadas tensões de $242 \mathrm{kV}$ até $800 \mathrm{kV}$. Nas subestações de transmissão, a tensão de transmissão é abaixada (trafos abaixadores) para níveis compatíveis para alimentar as várias subestações de distribuição (subtransmissão) ou subestações de indústrias de médio e grande porte alimentadas com $69 \mathrm{kV}$ a $138 \mathrm{kV}$.

Em subestações de distribuição e indústrias de pequeno porte, as tensões são novamente abaixadas (trafos abaixadores) visando alimentação de $13,8 \mathrm{kV}$ até $34,5 \mathrm{kV}$. Para serem utilizadas em sistemas de distribuição residenciais ou comerciais urbano, rural, temos os transformadores abaixadores para tensões de $440 \mathrm{~V}, 380 \mathrm{~V}$, $220 \mathrm{~V}$ e $110 \mathrm{~V}$ instalados em postes. 
Além destas aplicações clássicas, existem ainda transformadores reguladores, autotransformadores, transformadores de forno, reatores derivação dentre outros com uso específico em sistemas de potência ou sistemas fabris.

\section{- Definição das características dos transformadores [26]}

Antes do processo de aquisição de um transformador de potência destinado a sistemas elétricos, são realizados estudos complexos envolvendo o planejamento da evolução de carga nas regiões abrangidas, adequabilidade às condições de operação e manutenção, conformidade aos padrões e normas técnicas, intercambiabilidade com unidades existentes, quesitos de segurança e reserva técnica estratégica.

Destes estudos resulta uma série de características do transformador que visam satisfazer as necessidades de um sistema elétrico, tais como potência, tensão, freqüência, tipo de ligação, deslocamento angular, relações de transformação, suportabilidade elétrica da isolação e mecânica a curtos-circuitos, tipo e localização de comutadores, características térmicas, tipos de sistema de resfriamento, localização de acessórios, eventuais limitações dimensionais, atendendo as prescrições das normalizações técnicas de projeto e construção, de segurança e ambientais pertinentes.

As especificações traduzem estas necessidades em forma de documento técnico com o detalhamento adequado do transformador a ser adquirido, introduzindo ainda prescrições relacionadas a aprovação de documentação técnica (desenhos, manual de instruções, cronograma, plano de controle de qualidade, etc.), as garantias técnicas, bem com comprovações da conformidade do projeto através de inspeções e ensaios em matéria prima e/ou em fases importantes do processo de fabricação (enrolamentos, núcleo, parte ativa, etc.), bem como durante o recebimento do transformador completamente montado e acabado (ensaios de rotina, de tipo e especiais). 


\section{- Normalização Técnica}

A normalização é elaborada segundo procedimentos e conceitos emanados do Sistema Nacional de Metrologia, Normalização e Qualidade Industrial, sendo resultante de consenso nos diferentes fóruns que envolvem o Governo, Setor Produtivo, Comércio e Consumidores.

As normas visam obter a defesa dos interesses nacionais; a racionalização na fabricação e produção e na troca de bens e serviços; proteção dos interesses dos consumidores; segurança de bens e pessoas; preservação do meio ambiente; uniformidade dos meios de expressão e comunicação. [7], [8], [9] e [28].

\section{- Projeto dos Transformadores}

A partir das características elétricas e mecânicas definidas, desenvolve-se o projeto do transformador de potência, o qual pode ser decomposto em duas partes básicas: projeto elétrico e projeto mecânico.

\section{- Projeto Elétrico}

O projeto elétrico refere-se ao dimensionamento e definição da parte ativa do transformador, que é principalmente composta de núcleo e enrolamentos. A partir da potência nominal do transformador, o projeto elétrico tem início com a determinação das dimensões do núcleo e o número de espiras dos enrolamentos.

Do nível de tensão dos enrolamentos e níveis de isolamento correspondentes depende a escolha do tipo dos enrolamentos e o distanciamento entre os mesmos.

Para o dimensionamento da parte ativa são executados cálculos complexos, atualmente com o uso de computadores, a fim de tornar mais preciso e confiável os resultados: cálculos de elevação de temperatura no óleo e no enrolamento, suportabilidade as tensões de impulso, esforços de curto-circuito, campo magnético, blindagem magnética no tanque, perdas no núcleo, perdas nos enrolamentos, impedância e nível de ruído. 
Em complemento, define-se o comutador de derivações em carga, escolha dos acessórios elétricos, dimensionamento dos transformadores de corrente, elaboração da placa de identificação e composição dos manuais de instruções para montagem e energização.

\section{- Projeto Mecânico}

Com a parte ativa definida, o passo seguinte é o dimensionamento do tanque do transformador, o sistema de resfriamento, bem como o detalhamento de partes como enrolamento montado, ligação dos enrolamentos, a disposição das buchas, do comutador de derivações, do conservador de óleo, etc., como pode ser acompanhado na Figura 1.
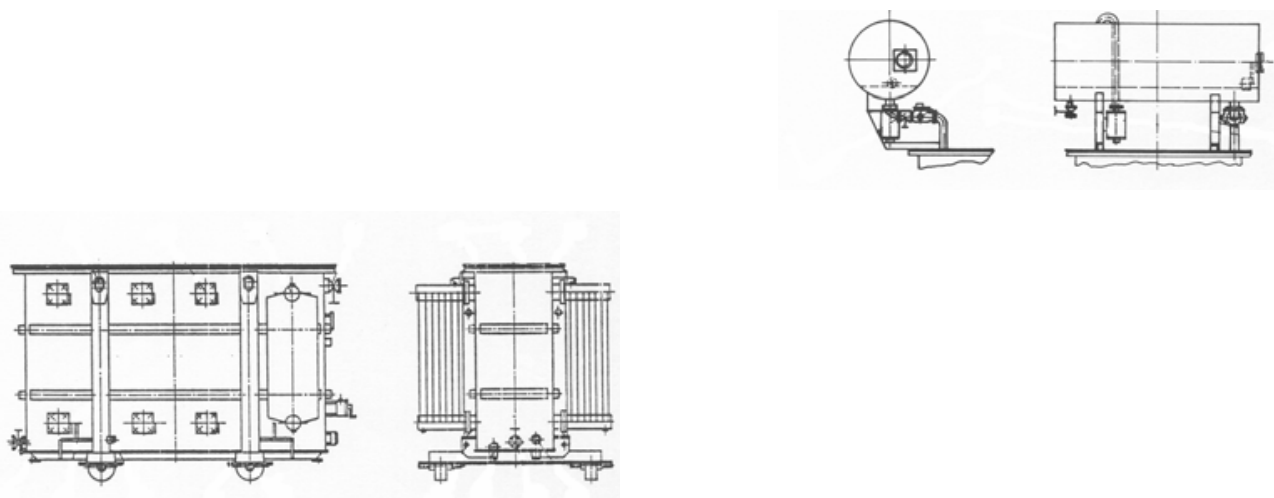

Figura A.1 Projeto Mecânico Típico

\section{- Aspectos Construtivos do Núcleo}

O núcleo, que forma o circuito magnético dos transformadores, é executado com aço silício de grão orientado, com alta permeabilidade magnética e com baixas perdas. Cuidados especiais são tomados durante as operações de corte e estampagem das chapas, visando evitar danos à camada isolante existente ou permitir o aparecimento de rebarbas que comprometeriam o desempenho do transformador.

As exigências de projeto dos transformadores prevêem a construção do núcleo do tipo envolvente (Shell Type) ou envolvido (Core Type). Com a finalidade 
de se obter melhor aproveitamento da orientação dos grãos na direção da laminação, o projeto do núcleo prevê que o fluxo magnético acompanhe o sentido da laminação, por meio de cortes em sentidos adequados das chapas.

Os pontos de transição das colunas do núcleo são obtidos através de chapas cortadas em um ângulo de $45^{\circ}$ e de forma tal que permita a superposição aos pares de forma intercalada, obtendo-se a minimização das perdas. A seção cruzada do núcleo é graduada formando aproximadamente um círculo que permite um melhor fator de laminação. A perfeita montagem do núcleo e sua fixação é de fundamental importância pois interfere diretamente na emissão de ruído audível.

Os furos para passagem dos tirantes nas chapas feitas no passado acarretavam deflexão do fluxo principal transversal ao sentido de laminação, aumentando as perdas elétricas (perdas no ferro), motivo pelo qual o projeto do núcleo prevê o emprego de fitas com fibra de vidro ou aço para obter a adequada prensagem mecânica.

As chapas de aço silício que formam o circuito magnético, prensadas pelo processo exposto, compõem uma unidade independente, que é emoldurada por um conjunto de ferragens. Este conjunto tem o objetivo de sustentar e fixar o núcleo e enrolamentos (parte ativa) ao tanque em sua parte inferior, através de parafusos de travamento, e, na parte superior por meio de distanciadores e parafusos isolados. Os pacotes de chapas, assim como os elementos e estrutura de fixação do núcleo são devidamente aterrados para evitar o fenômeno de carregamento capacitivo associado. Este aterramento é feito em local acessível através de janela de inspeção da tampa, podendo ser desconectado para verificação da resistência do isolamento do núcleo.

Para propiciar o resfriamento do núcleo, quando necessário, são previstos canais de circulação de óleo entre as suas chapas montadas convenientemente espaçadas. Podemos acompanhar exemplo de construção do núcleo na Figura A.2. 


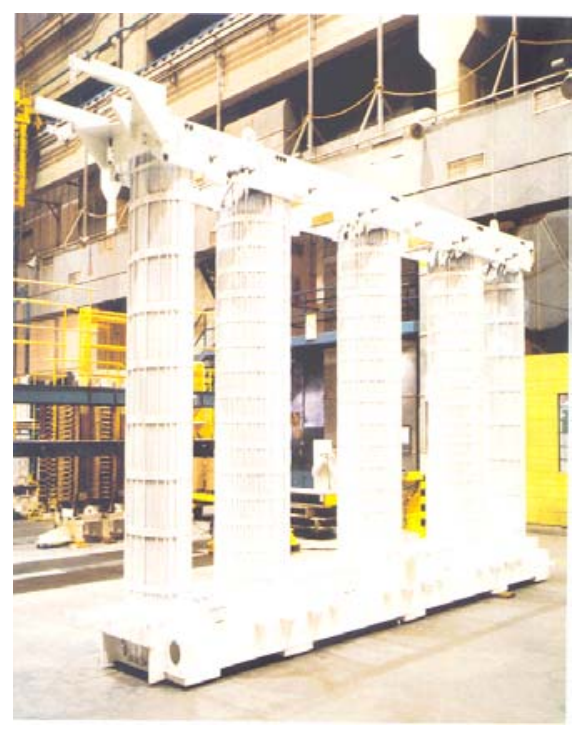

Figura A.2 - Vista do Núcleo Montado (SIEMENS)

\section{- Aspectos e Características dos Enrolamentos}

Nos enrolamentos empregam-se normalmente condutores retangulares de cobre isolados com papel isolante do tipo kraft. Também podem ser empregados cabos transpostos que são feixes formados por vários condutores de cobre retangulares, isolados individualmente por verniz especial compatível (resistente) ao óleo isolante. $\mathrm{O}$ feixe de condutores é isolado adicionalmente por camadas de papel isolante do tipo kraft que tem suportabilidade térmica média de $95^{\circ} \mathrm{C}$, o que representa elevação de temperatura de $55^{\circ} \mathrm{C}$ além da temperatura ambiente máxima de $40^{\circ} \mathrm{C}$.

Em alguns casos, conforme a exigência do projeto pode ser utilizado papel isolante do tipo termoestabilizado que possui capacidade térmica média superior $\left(105^{\circ} \mathrm{C}\right)$ em relação ao papel tipo kraft convencional $\left(95^{\circ} \mathrm{C}\right)$. Assim, o papel convencional é conhecido como base $55^{\circ} \mathrm{C}$ e o papel termoestabilizado como base $65^{\circ} \mathrm{C}$ em relação a temperatura ambiente máxima de $40^{\circ} \mathrm{C}$. 
A isolação principal entre os enrolamentos é obtida através de cilindros e anéis de cantoneira compostos de folhas de papelão isolante tipo presspan, impregnáveis em óleo isolante.

Os enrolamentos são fabricados com bobinas circulares que apresentam maior resistência mecânica a esforços radiais de curtos - circuitos, os quais são muito comuns em um Sistema Elétrico. Normalmente o enrolamento de tensão inferior é montado junto ao núcleo e o enrolamento de tensão superior externamente.

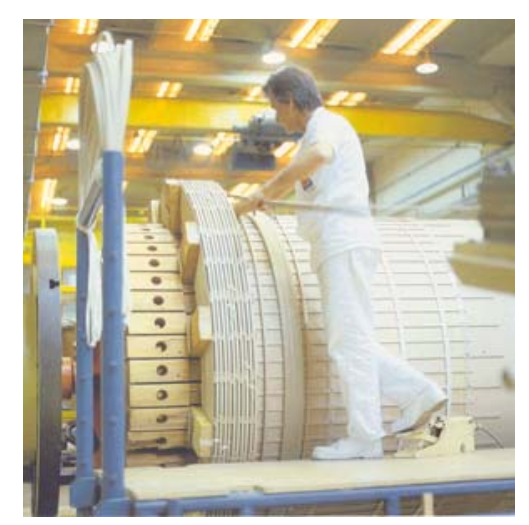

Figura A.3 - Enrolamento típico de um transformador de potência. (SIEMENS)

O dimensionamento dos enrolamentos, dos canais de refrigeração, da isolação entre enrolamentos entre outros detalhes construtivos é obtido por cálculo, considerando aspectos elétricos, térmicos e mecânicos, podendo ser fabricado de diversas maneiras: camada simples; camada dupla; cilíndrico cruzado, helicoidal simples; helicoidal duplo; bobinas duplas simples; bobinas duplas entrelaçadas.

A escolha do tipo a ser usado depende das características do transformador, tais como :

- Potência;

- Tensão;

- Enrolamentos;

- Sistema de Resfriamento.

Além do citado anteriormente também devem ser considerados fatores de ordem econômica e operacional. 


\section{- Aspectos e Características da Parte Ativa}

A parte ativa é o conjunto montado formado pelo núcleo e enrolamentos do transformador, complementada por outros materiais e componentes: as ligações dos enrolamentos; as ligações do comutador; as ligações para as buchas; os transformadores de corrente; as barreiras isolantes (enrolamento - tanque; enrolamento - enrolamento; enrolamento - núcleo); comutador sem carga ou comutador de derivações em carga, como pode ser acompanhado na Figura A.4.

Após a finalização da montagem da parte ativa, esta é submetida a um processo de secagem em estufa, visando eliminar a umidade residual do material isolante. A presença desta umidade diminui a rigidez dielétrica do isolamento, colocando em risco a vida útil do transformador. Apesar do transformador ser um equipamento estático, a denominação parte ativa é dada devido ao fato de ser responsável pelas características elétricas do transformador quando eletro magneticamente excitada.

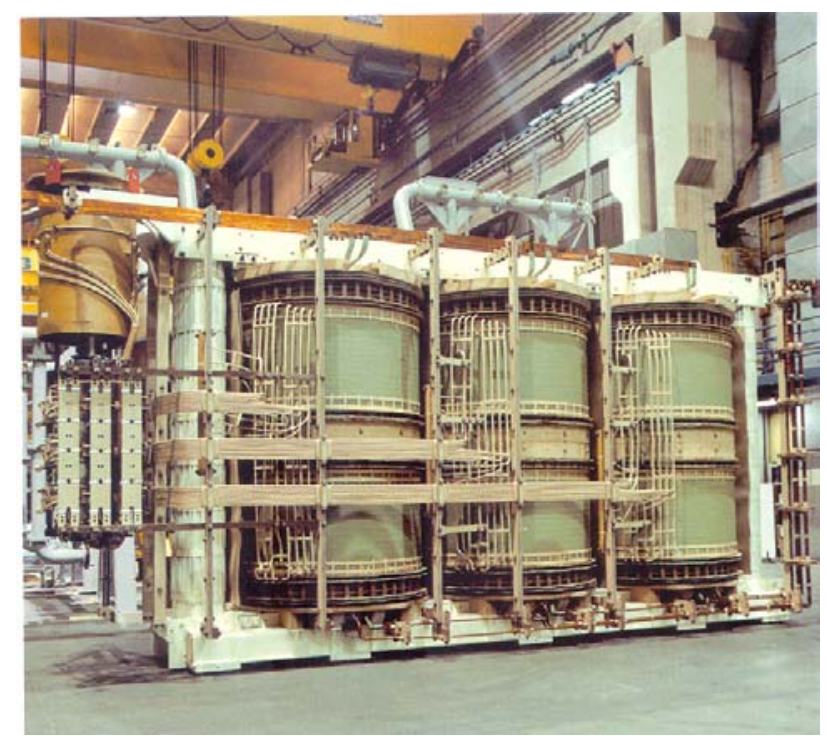

Figura A.4 - Vista da Parte Ativa Montada. (SIEMENS) 


\section{- Aspectos e Características dos Comutadores}

Os comutadores são dispositivos usados no transformador com a função de se conseguir diferentes relações de transformação, ou seja, a variação do número de espiras de um dos enrolamentos e consequentemente diferentes relações de tensões. Estes dispositivos podem ser separados em dois tipos: comutador de derivações sem tensão; comutador de derivações em carga.

\section{- Comutador sem Carga}

Os comutadores de derivações sem tensão são empregados para alterar a relação de transformação com o equipamento desenergizado. Normalmente são montados verticalmente no tanque do transformador, em um dos lados, ou em local conveniente. Operado de forma manual através de acionamento acessível do solo, possui também bloqueio e travamento mecânico, sendo instalados no início, meio ou fim do enrolamento visando possibilitar religação direta, série paralelo, etc.

As réguas de contato, reciprocamente pressionadas por meio de diversas molas, permite o deslizamento praticamente isento de desgaste mecânico. A corrente fluindo paralelamente em duas pontes de contato, atrai uma à outra, incrementando a pressão do contato nos esforços de curtos - circuitos. A baixa corrente em cada ponto de contato, com as diversas barras em paralelo, permite reduzir o aquecimento nos pontos de transferência.

\section{- Comutador sob Carga}

Os comutadores de derivações em carga regulam a tensão automaticamente com o transformador em operação (em carga), sendo consistido de pré seletor de derivações, chave seletora e chave comutadora e mecanismo de acionamento motorizado na parte externa.

A Figura A.5 pode ser visto um comutador tipo garfo ou cilíndrico típico.O pré seletor e a chave seletora são instalados normalmente no interior do tanque do transformador logo abaixo da chave comutadora que fica em câmara (cilíndrica ou 
retangular) de forma estanque para não contaminar o óleo do transformador. Este tipo de comutador trouxe inúmeras vantagens operacionais, além de facilitar a construção dando maior segurança ao equipamento.

As bolhas de gás formadas durante a comutação em carga são contidas no tanque do comutador e conduzidas através de tubulação diretamente ao conservador de óleo do comutador, separado do conservador do tanque do transformador, provida de secador de ar a silicagel.

Qualquer nova posição do comutador é inicialmente pré selecionada pela chave pré seletora do comutador sob carga energizado e sem carga. Então, a chave comutadora efetuar a comutação para a nova posição. Completada a operação, os contatos móveis param automaticamente. A chave reversora provoca a reversão ou o encaminhamento da derivação modificada e do mesmo modo opera energizada e sem carga. Os contatos fixos do pré seletor da chave comutadora são fabricados em forma circular para possibilitar a maior eficiência do resfriamento.

Os contatos móveis são individuais construídos em barras curvas, por meio dos quais a transmissão de corrente de fuga é garantida sem contribuir para o sobreaquecimento, no caso de esforços de curtos circuitos. O método de construção de gaiola redonda cilíndrica do pré seletor e da chave seletora produz um conjunto mecanicamente robusto e de elevada rigidez dielétrica.

O sistema de comutação é baseado no princípio de armazenamento de energia por mola, o que permite a operação de transferência de carga para a derivação seguinte em menos de 60 milisegundos, utilizando um conjunto de resistores visando reduzir os efeitos da transição em carga. Uma vez iniciado o processo de transferência, o mesmo deve ser completado sem possibilidade de falha, pois a energia cinética fornecida pelas molas só permite posições de repouso da chave comutadora após ter atingido o contato principal no fim do deslocamento, o que amplia a segurança operacional. O conjunto de contatos móveis se desloca em planos paralelos, sendo dimensionados de forma adequada contra desgastes por transitórios de corrente.

Existem várias maneiras de se fazer a conexão do comutador nos enrolamentos do transformador, dependendo do nível de tensão (alta, baixa ou média tensão), do tipo de ligação (delta, estrela, neutro), da localização no enrolamento 
(meio ou fim), cada um deles necessitando estudos para definição de suportabilidades a curtos-circuitos e sobretensões a que estará sujeito o transformador no sistema elétrico.

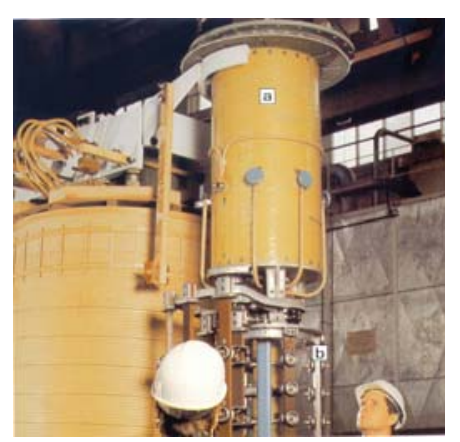

Figura A.5 - Comutador sob Carga - Chave Seletora e Comutadora. (SIEMENS)

A vida estimada dos contatos, definida como mínimo de 500 mil operações, depende de vários fatores: corrente de carga, transitórios, curtos circuitos e sobretensões originárias no sistema elétrico a que estão sujeitos, [10].

Assim, a vida dos contatos tem relação direta com a sua localização e utilização no transformador de potência.

Quando o transformador está em operação normal, o óleo que envolve a chave comutadora apresenta-se carbonizado e após um período de tempo médio de 6 anos ou 60mil operações necessita de alguma intervenção (substituição, tratamento, filtragem, etc.) [10].

Atualmente, com o uso de sistemas apropriados de filtros em comutadores cilíndricos estes tempos de intervenção são substancialmente elevados em relação ao critério originalmente definido.

A unidade de acionamento motorizado permite através de suas transmissões e eixos, a operação do comutador para qualquer posição escolhida (manual ou automaticamente). Após cada mudança de posição, o acionamento é freado eletromagneticamente.

Quando for alcançada quaisquer das posições extremas da faixa de comutação, um sistema de bloqueio é acionado provendo o travamento. Além disto, as posições extremas são protegidas por mecanismos de bloqueio mecânico de fím de curso, o que é usado quando da operação manual. 
A inserção da manivela do acionamento desliga automaticamente o acionamento motorizado. $\mathrm{O}$ acionamento motorizado é adequado para operação em paralelo e sob comando automático.

\section{- Aspectos e Características do Tanque e Conservador de Óleo}

$\mathrm{O}$ tanque do transformador tem as funções de conter o líquido isolante e viabilizar o seu transporte até o local da instalação. Todos os materiais das vedações são adequados às condições a que são impostas pelo óleo, temperatura e ambiente. Um exemplo de tanque encontra-se na Figura 2.6.

Executado em chapa de aço carbono possui formato retangular na maioria das vezes, sendo as soldas de costura dupla com o intuito de garantir a perfeita estanqueidade. No fundo do tanque, além dos esforços longitudinais, existe previsão de base de apoio para transporte e montagem de rodas bidirecionais (quando especificado). As laterais do tanque são reforçadas com perfis horizontais e verticais dando ao tanque resistência a pressão e ao vácuo.

A borda superior o tanque é terminada em uma moldura plana, sobre a qual é aparafusada uma tampa, com guarnições de borracha plana sintética. Nas duas laterais maiores, na parte superior dos reforços verticais, existem quatro dispositivos para levantamento do transformador completo e na parte inferior próximo a base de apoio ou rodas, existem quatro apoios para macaco.

Concluídas as soldas no corpo do tanque, este sofre um processo de limpeza com jato de areia, recebendo em seguida um processo de pintura adequada interna e externamente (anticorrosiva, acabamento estético, compatível com óleo isolante) para sua conservação em relação a intempéries e temperaturas internas a que está submetido.

Os tanques estão equipados com registros e válvulas para drenagem - enchimento amostragem de óleo, terminais de aterramento, olhais de tração, suportes para acessórios, placa de identificação, acionamento do comutador, caixa de ligações, etc.

A parte ativa do transformador é fixada na tampa do tanque e no fundo, através de elementos apropriados previstos nas ferragens de prensagem do núcleo. A 
tampa é aparafusada ao tanque e dependendo do tipo construtivo do tanque, poderá ser feito na parte superior (convencional) ou na parte inferior (tipo campânula).

Dependendo do sistema de resfriamento especificado, os radiadores poderão ser acoplados as paredes do tanque ou instalados em bateria separada, acontecendo o mesmo com os trocadores de calor resfriados a ar ou à água.

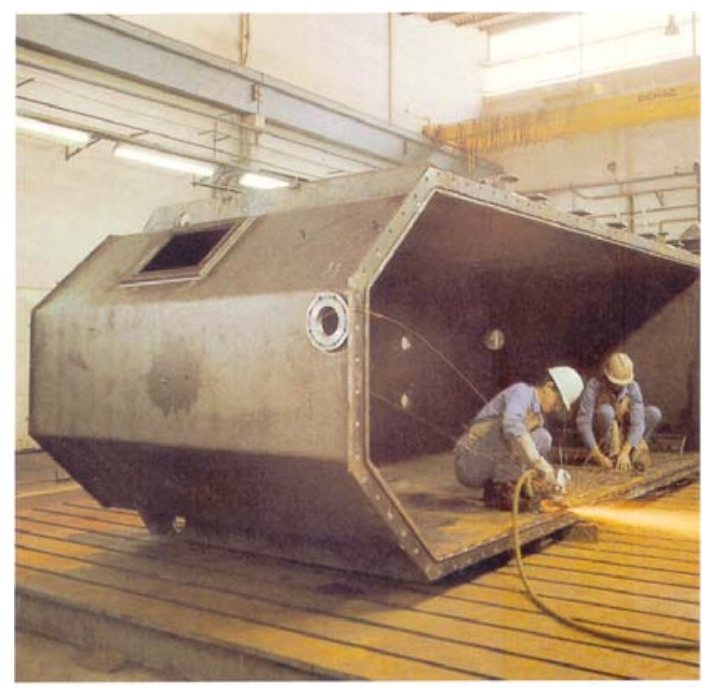

Figura A.6 - Vista geral do tanque (SIEMENS)

\section{- Sistema de Preservação do Óleo Isolante}

O sistema de preservação do líquido isolante é constituído do conservador via de regra na forma cilíndrica. Este dispõe de câmaras separadas para o óleo do comutador de derivações em carga (quando existir) e do tanque principal do transformador, localizado em um dos lados do tanque.

O seu dimensionamento é calculado para compensar as variações do volume de óleo devido ao aquecimento natural do transformador quando em operação, desde a temperatura de $0^{\circ} \mathrm{C}$ até a temperatura máxima permissível de projeto.

A pequena superfície do líquido em contato com o ar no interior do conservador e as temperaturas baixas contribuem para baixos índices de oxidação.O respiro é feito através de um secador de ar a base de silicagel, sendo normalmente equipado (convencional) com bolsa de borracha que tem a finalidade de evitar o contato entre o óleo e o ar atmosférico. 
Na tubulação entre o tanque e o conservador é montado um relé de gás tipo Buchholz, provido de bóias e contatos visando alarme ou desligamento do transformador, dependendo do volume e fluxo de gases gerados de forma excessiva e anormal internamente ao transformador, por exemplo, devido a curtos - circuitos internos, descargas elétricas, mau contato e outros.

$\mathrm{Na}$ lateral do conservador, o indicador magnético de nível de óleo mostra a posição do nível de óleo, com um contato de nível mínimo para alarme ou desligamento do transformador.

O ajuste da bóia do indicador, o enchimento com óleo e a limpeza do conservador são possíveis por uma abertura de inspeção nas laterais do conservador, possuindo ainda registros de enchimento, drenagem e suportes para levantamento e apoio.

\section{- Aspecto e Características das Buchas, [23]}

As buchas são dispositivos ou estruturas de materiais isolantes que asseguram a passagem isolada de um condutor através de uma parede não isolante. As buchas podem ser divididas em buchas isolantes secas (porcelana) ou buchas condensivas (isolamento com camadas capacitivas).

Todos os tipos de buchas são desmontáveis sem necessidade de abrir a tampa do transformador. Cuidados especiais são tomados quando da aplicação em transformadores com elevadas correntes.

Até a classe de $34,5 \mathrm{kV}$ os transformadores possuem buchas de porcelanas cheias de óleo, consistindo de um corpo isolante de porcelana atravessado por um condutor de cobre rígido.

$\mathrm{Na}$ parte exterior este condutor tem elementos que formam um conjunto de vedação estanque ao óleo do transformador mas que, durante o enchimento do transformador permite a saída de ar acumulado na bucha, denominado sangria de ar.

Para tensões maiores do que $34,5 \mathrm{kV}$ recomenda-se o emprego de buchas condensivas. As buchas condensivas tem tamanho reduzido em relação ao tipo porcelana - óleo e são compostas de núcleo, isolador e condutor. 
O núcleo é composto de um cilindro isolante, alternando-se cilindros condutores (lâmina metálica) e cilindros isolantes (papel isolante).

A medida que se aproximam da parte externa, os cilindros condutores vão diminuindo de comprimento, obtendo-se ao redor do primeiro cilindro condutor uma série de capacitores para permitir uma distribuição uniforme de potencial no sentido radial.

O último cilindro condutor é ligado ao flange da bucha de modo a se obter o aterramento do núcleo e, quando necessário, realização de ensaios de avaliação do estado das buchas e características originais.

Sobre o conjunto descrito acima, coloca-se um corpo de porcelana (ou polimérico) apropriado para se obter uma bucha adequada para uso de instalação ao tempo.

Sobre o condutor é enrolado o núcleo descrito acima, podendo ser de dois tipos: tubo metálico ou condutor maciço.

O tubo metálico, por onde é introduzido um condutor flexível que sai do transformador, é soldado ao pino superior da bucha.

O condutor maciço é o varão não desmontável que atravessa toda extensão da bucha.

As buchas condensivas possuem sistema de preservação de óleo independente do óleo do transformador. Este óleo ocupa espaço entre o núcleo e o isolador. Possui sistema de compensação com indicador de nível de óleo.
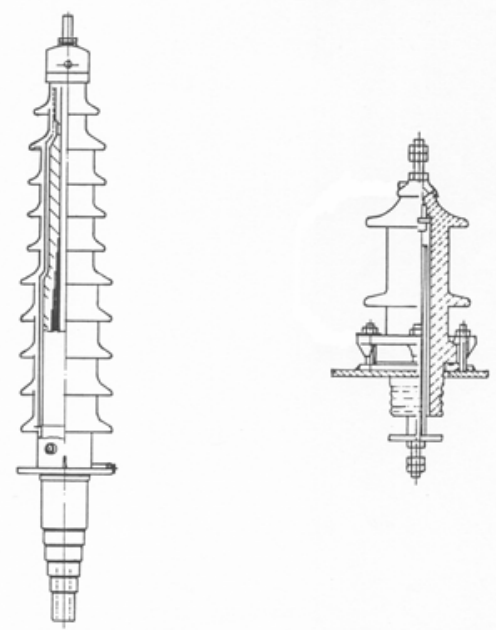

Figura A.7 - Buchas Típicas de AT e MT 


\section{- Aspectos e Características do Sistema de Resfriamento}

Os transformadores devem ser classificados conforme o método de resfriamento a ser implementado, sendo apresentado neste capítulo ênfase para sistemas com resfriamento natural e com estágios de ventilação forçada de ar, apesar da existência de vários outros tipos como pode ser acompanhado na Tabela 2.1.

Tabela A.1 - Símbolos dos Sistemas de Resfriamento

\begin{tabular}{|l|l|}
\hline Natureza do Meio de Resfriamento & Símbolo \\
\hline Óleo & O \\
\hline Líquido isolante sintético não inflamável & L \\
\hline Gás & G \\
\hline Água & W \\
\hline Ar & A \\
\hline Natureza da Circulação & Símbolo \\
\hline Natural caso de óleo, fluxo não & F \\
\hline $\begin{array}{l}\text { Forçada (no cada } \\
\text { dirigido) }\end{array}$ & D \\
\hline Forçada com fluxo de óleo dirigido & \\
\hline
\end{tabular}

Os transformadores em líquido isolante devem ser designados por grupo de quatro símbolos para cada método de resfriamento. A ordem na qual os símbolos devem ser utilizados consta da Tabela 2. Os grupos de símbolos correspondentes a diferentes métodos de resfriamento devem ser separados por meio de traço inclinado. 
Tabela A.2 - Ordem dos Símbolos dos Sistemas de Resfriamento

\begin{tabular}{|l|l|l|l|}
\hline \multicolumn{1}{|c|}{ Primeira Letra } & \multicolumn{1}{|c|}{ Segunda Letra } & Terceira Letra & Quarta Letra \\
\hline $\begin{array}{l}\text { Indicativa do meio de resfriamento } \\
\text { em contato com os enrolamentos }\end{array}$ & $\begin{array}{l}\text { Indicativa do meio de resfriamento em } \\
\text { contato com o sistema de resfriamento } \\
\text { externo }\end{array}$ \\
\hline $\begin{array}{l}\text { Natureza do } \\
\text { Meio } \\
\text { de Resfriamento }\end{array}$ & $\begin{array}{l}\text { Natureza } \\
\text { Circulação }\end{array}$ & $\begin{array}{l}\text { Natureza do Meio de } \\
\text { Resfriamento }\end{array}$ & $\begin{array}{l}\text { Natureza da } \\
\text { Circulação }\end{array}$ \\
\hline
\end{tabular}

Um transformador imerso em óleo isolante mineral com circulação natural de óleo isolante e ar é designado por ONAN. Este mesmo transformador ao um estágio de ventilação forçada a ar tem agora a designação para este estágio de ONAF, sendo a designação completa desta unidade ONAN/ONAF.

\section{- Método de Resfriamento ONAN}

No caso das figuras 2.8 e 2.9 mostradas a seguir, o resfriamento do transformador é feito por meio de circulação natural do óleo através de radiadores (1) de aletas flangeadas.

As aletas (2) são fabricados em chapa de aproximadamente $1,2 \mathrm{~mm}$ de espessura, estampadas e soldadas aos pares. Nas extremidades das aletas estão soldados dois tubos adutores (3). O líquido isolante (4), aquecido em contato com os enrolamentos (5) e com o núcleo (6), efetua um ciclo de convecção após seu resfriamento nas aletas dos radiadores. Também o ar externo (7), em contato com as aletas, renova-se por convecção, completando o ciclo de resfriamento.

Os radiadores são flangeados sobre válvulas borboletas (8) e podem ser desmontados para transporte do transformador, estando equipado com bujões superior e inferior (9), bem como manípulo (10) que pode interromper a passagem de 
óleo do transformador para o radiador, com indicação fechada e aberta e travamento em ambas as posições.

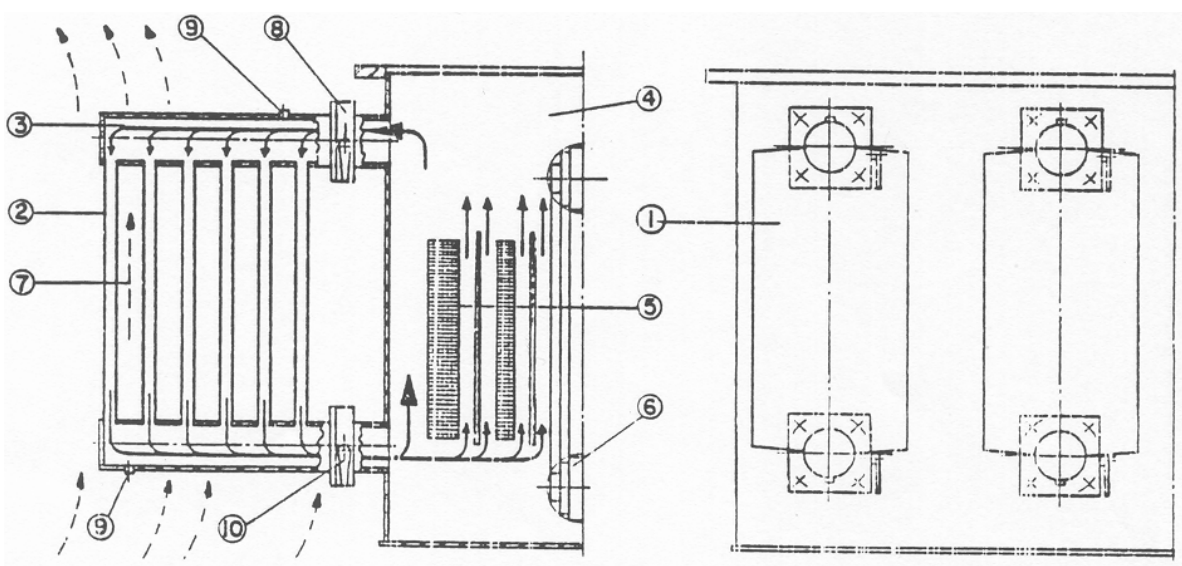

Figura A.8 - Sistema de Resfriamento - ONAN

\section{- Método de Resfriamento ONAN / ONAF}

O primeiro estágio de resfriamento de um transformador é feito pela circulação natural do líquido isolante ONAN através dos radiadores (1). Os radiadores formados por aletas (2) são flangeadas sobre válvulas borboleta (3) que permitem desmontá-los para transporte. O líquido isolante (4), aquecido em contato com os enrolamentos (5) e com o núcleo (6), efetua um ciclo de convecção após seu resfriamento nas aletas dos radiadores. $\mathrm{O}$ ar externo (7) em contato com as aletas renova-se por convecção, como visto na Figura 2.9.

Quando projetado e construído para tal finalidade, o segundo estágio de resfriamento do transformador se dá por ventilação forçada, ONAF, com a qual normalmente se consegue aumentar a de $20 \%$ a $30 \%$ da potência nominal. Ventiladores instalados (8) atuando com fluxo de ar na vertical ou na horizontal sobre um grupo de radiadores aceleram a renovação do ar entre as aletas e melhoram a eficiência do ciclo de resfriamento descrito para o primeiro estágio. Os ventiladores são acionados por motores trifásicos e estão envolvidos por uma carcaça metálica de proteção e fixados nos próprios radiadores por meio de suportes aparafusados nos tubos inferiores (9) ou laterais e assentam-se sobre amortecedores de neoprene. 
O comando da ventilação forçada pode ser automático por contato de termômetro (10) ou manual via interruptor local ou remoto. Uma caixa de comando (11) montada na parede lateral do tanque contém contatores, fusíveis, relés interruptores, com a finalidade de ligar ou desligar os ventiladores.

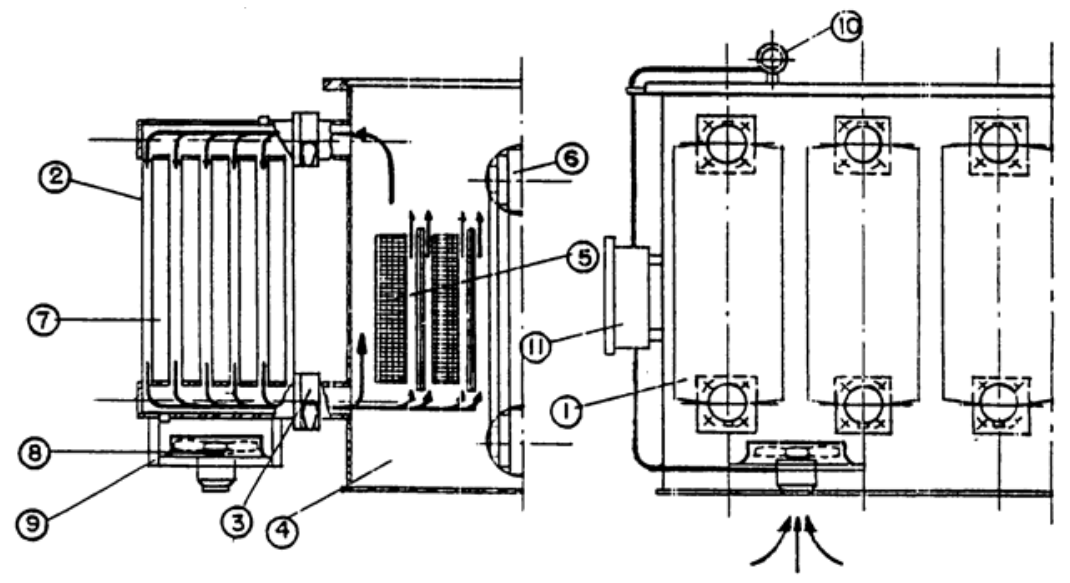

Figura A.9 - Sistema de Resfriamento - ONAN/ONAF

Outros métodos de resfriamento podem ser obtidos por trocador de calor óleo/água e bomba de óleo (OFWF); circulação forçada de óleo e circulação natural de ar (OFAN) com radiadores e bomba de óleo; circulação forçada de óleo e circulação forçada de ar com radiadores, bomba de óleo e ventilador (OFAF). 